\title{
Biostratigraphy and magnetostratigraphy of the uppermost Tithonian-Lower Berriasian in the Theodosia area of Crimea (southern Ukraine)
}

\author{
Vladimir G. BAKHMUTOV ${ }^{1}$, Eva HALÁSOVÁ2, Daria K. IVANOVA ${ }^{3}$, Štefan JÓZSA², Daniela REHÁKOVÁ ${ }^{2}$ \\ and William A.P. WIMBLEDON ${ }^{4, *}$ \\ 1 National Academy of Science of Ukraine, Institute of Geophysics, Palladina Av. 32., 03142 Kyiv, Ukraine \\ 2 Comenius University, Department of Geology and Palaeontology, Faculty of Natural Sciences, Ilkovičova 6, 84215 \\ Bratislava, Slovak Republic \\ 3 Bulgarian Academy of Sciences, Geological Institute, Acad. G. Bonchev Street, BI. 24, 1113 Sofia, Bulgaria \\ 4 University of Bristol, School of Earth Sciences, Wills Memorial Building, Queens Road, Bristol BS81RJ, United Kingdom
}

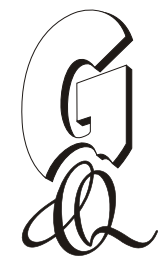

Bakhmutov, V.G., Halásová, E., Ivanova, D.K., Józsa, Š., Reháková, D., Wimbledon, W.A.P., 2018. Biostratigraphy and magnetostratigraphy of the uppermost Tithonian-Lower Berriasian in the Theodosia area of Crimea (southern Ukraine). Geological Quarterly, 62 (2): 197-236, doi: 10.7306/gq.1404

Associate editor: Jacek Grabowski

\begin{abstract}
We present evidence for the uppermost Jurassic-lowest Cretaceous interval in Crimea, coastal southern Ukraine. Three facies zones are distinguished in the upper Dvuyakornaya and the Mayak formations of the eastern Crimean Peninsula: basinal, slope and toe-of-slope zones. In this interval we identify the lowest Berriasian Jacobi and Grandis subzones of authors, in expanded form, exceeding 160 metres in thickness. We present new magnetostratigraphic interpretations, and identify two normal and two reversed polarity intervals, assigned to M19n, M18r, M18n and M17r, with M19n2n, M19n1r and M19n1n identified in the uppermost Dvuyakornaya Formation. In the Mayak Formation we record the top of M19n.1n, with M18r, M18n and a thick M17r above. In these two formations component calpionellid species have been identified which characterise the Alpina, Ferasini and Elliptica subzones (Calpionella Zone). In M19n, the FADs of the calcareous nannofossils Hexalithus strictus, Cruciellipsis cuvillieri, Nannoconus wintereri, N. steinmannii minor and N. kamptneri minor are found, which is consistent with other Tethyan regions. N. steinmannii steinmannii and N. kamptneri kamptneri first appear in M18r at Ili Burnu. Specimens of the apparently Tithonian foraminiferan index Anchispirocyclina lusitanica are found, but in the Berriasian lower Mayak Formation.
\end{abstract}

Key words: Berriasian, magnetostratigraphy, calcareous nannofossils, calpionellids, foraminiferans, ammonite biostratigraphy.

\section{INTRODUCTION}

In Ukraine, limited shallow-marine Berriasian carbonates have been recorded in the west (Gutowski et al., 2005), and Rosso Ammonitico calpionellid-bearing limestones associated with volcanics in the south-west (Pieniny Klippen Belt; Reháková et al., 2011), but uppermost Jurassic-lowermost Cretaceous, deeper-water marine sedimentary rocks are welldeveloped and extensively exposed only in the south, where they crop out in the Crimean Peninsula.

Higher parts of the Berriasian are represented in western Crimea, to the south of Bakhchisaray (Arkad'ev et al., 2000),

* Corresponding author, e-mail: mishenka1@yahoo.co.uk Received: June 26, 2017; accepted: February 15, 2018; first published online: April 10, 2018 whereas thicker and more complete sections through the lower parts occur only in mid-Crimea (near to Bilohirs'k; Arkad'ev et al., 2005) and in the east of the peninsula, where the succession is amongst the thickest in Europe - the area discussed in this publication. In palaeogeographical terms, these sediments were deposited in the south Crimean Trough, a seaway that was a remnant of Palaeotethys, lying immediately south of the Ukrainian Shield massif and north of various continental plate fragments. The latter, Cimmerian elements, such as the Pontides, lay just north of a subduction zone on the margin of Tethys proper (Meijers et al., 2010). On the basis of shared macro- and microbiota, the Crimean seaway communicated eastwards to the Caucasus, and westwards towards the Moesian Platform (Bulgaria), central Europe (S Poland, Slovakia and Czech Republic) and Mediterranean Tethys.

The following is a contribution towards the biostratigraphy and magnetostratigraphy of the Lower Berriasian of eastern Crimea. It reports on fossil finds and stratigraphical conclusions based on concerted fieldwork that commenced in 2004, as a 
contribution to the work of the Berriasian Working Group (International Subcommission on Cretaceous Stratigraphy) and part of an effort to document key $\mathrm{J} / \mathrm{K}$ boundary sections. In particular, we have focussed on the documentation of magnetozones M19n-M17r, thus the upper Crassicollaria Zone and Calpionella Zone and the ammonite Jacobi and Grandis subzones, as well as important nannofossil datums that constrain these horizons.

Earlier field seasons focussed on reconnaissance and establishing a coherent lithostratigraphy for the presumed topmost Tithonian-Lower Berriasian interval in central Crimea near Bilohirs'k (south of Balki and Krasnoselivka), in the eastern peninsula around Yuzhne (= Sultan Sala), and in coastal outcrops to the south of Theodosia (= Feodosiya). Later study by us (2008-2014) has focussed primarily on the Theodosia area and the precise sampling and calibration of ammonites, calpionellids and calcareous nannofossils, plus foraminiferans, integrated precisely with palaeomagnetic sampling. Our sampling in the last ten years was aimed at establishing a sound lithostratigraphic column, which has brought a new accuracy to the study of this interval and the area; and, for the first time, we precisely calibrate magnetic zones and useful micropalaeontological markers with such a column.

\section{HISTORICAL AND GEOLOGICAL SETTING}

The study of the Berriasian of the southern coast of Ukraine near Theodosia started with the work of Sokolov (1886) who named the "Theodosia marls" and made a description of a few berriasellid and other ammonites. Retowski (1894) gave a fuller description of this fauna. His significant ammonite collection came from an inland area a little over $3 \mathrm{~km}$ south-west of the town, on the hill ridge of Tete-Oba. Sadly, though a key locality in studies of the biostratigraphy of the $\mathrm{J} / \mathrm{K}$ interval, Retowski (1894) recorded no geological or lithostratigraphic context for his ammonites; only mentioning that his specimens were derived from two "marl" units, a grey one below and a yellow one above. He was, however, the first to notice the limestone breccias and grainstones that typify the Theodosia (and Yuzhne) sequences (often referred to as sandstones in the Russian literature). Retowski's (1894) publication was, internationally, amongst the first monographic works on lowermost Cretaceous ammonites. His material from the so-called "Feodosia Marl" (e.g., Druschits, 1975) he attributed to the uppermost Jurassic, though later it was seen as Berriasian (Mazenot, 1939; Le Hégarat ,1973). His described 'fauna' comprised species from more than one stratigraphical level, and perhaps more than one locality (to be the subject of a later account).

The eastern Crimean Lower Berriasian sections, both inland and coastal, lie to the south and south-west of Theodosia (Druschits, 1975; Kvantaliani and Lysenko, 1979; Bogdanova et al., 1981, 1984; Kvantaliani, 1999; Glushkov, 1997; Arkad'ev et al., 2012). Bogdanova et al. (1984) recorded ammonite-bearing correlative sections SE of Yuzhne $(10 \mathrm{~km} \mathrm{WSW}$ of Theodosia) - Bogdanova's "Sultanovka", and at Nanikove (= Barak Gol), another $6 \mathrm{~km}$ to the west (Bogdanova et al., 1984). Kvantaliani (1999) had collected extensively from Yuzhne and also at higher levels in the Sary Su valley (SE of Balki).

A modern account of the lithostratigraphy of the $\mathrm{J} / \mathrm{K}$ boundary interval near Bilohirs'k and Theodosia has been lacking, with, up to the present, only stylised, and sometimes composite, sections published (e.g., Arkad'ev et al., 2007 - Balki; Druschits, 1975 - Theodosia). In general, lithological descriptions and bed and member thicknesses have been somewhat imprecise, or simply estimated (Bogdanova et al., 1984), and measurements vary between published accounts (e.g., Arka- d'ev et al., 2005, and Lobacheva et al. cited in Arkad'ev et al., 2005). Thicknesses given here for the Theodosia sections may be compared to earlier publications (references in Arkad'ev et al., 2012): they are normally thicker, and sometimes substantially thicker, than those given previously.

As to a biostratigraphic context and a Late Tithonian and Berriasian ammonite biozonation, thus far, no representative of presumed latest Tithonian ammonite taxa such as Protacanthodiscus and Durangites has been found in Crimea. Isolated specimens of Oloriziceras cf. schneidi have been recorded west from Ili Burnu (Arkad'ev, 2004) in Dvohyakirna Bay, recorded as coming from $\sim 150 \mathrm{~m}$ below the level of the prominent two-metre breccia, and Paraulacosphinctes cf. transitorius was found in an intermediate level at Yuzhne (Arkad'ev and Rogov, 2006). The same species was next found on the coast two kilometres west of Ili Burnu. Two species of Paraulacosphinctes were there placed (Guzhikov et al., 2012: fig.14) in a magnetic reversal identified as M19r; and, above, a specimen Neoperisphinctes cf. falloti in a reversal labelled as M19n.1r. These assignments are not consistent with evidence from other regions, nor with our results presented below. In France, for instance at Le Chouet, the Andreaei Zone is more or less equivalent to M19r, and Paraulacosphinctes is typical of the Microcanthum Zone and the lowermost Andreaei Zone: and the majority of the Microcanthum Zone falls in magnetozone M20n. At Le Chouet and Puerto Escaño the base of M19n.2n is more or less coincident with the base of the Jacobi Subzone, and M19n.1r falls well inside the Jacobi Subzone (Pruner et al., 2010; Wimbledon et al., 2013) and within the Calpionella Zone. At Puerto Escaño the last $N$. falloti is seen in the top bed assigned to the "Durangites Zone", almost at the base of M19.2n. In eastern Crimea, the few Tithonian ammonites present are not sufficient to construct a biozonation.

In the Berriasian on the coast south of Theodosia only ammonites attributable to the Jacobi or Grandis subzones are represented. The Tirnovella occitanica Zone has been cited inland in the peninsula, but not on the southeastern coast, and no occurrence of a basal, Subthurmannia subalpina, fauna has ever been noted. On Crimea's southeastern coast, the Fauriella boissieri Zone is absent, but it has been identified in a clay pit in the Zavodskaya Balka $(2.5 \mathrm{~km}$ west of Theodosia harbour; Arkad'ev et al., 2010). Tithonian to Berriasian strata have received much attention for their ammonites, but they have also been studied for foraminifera (see Kuznetsova and Gorbachik, 1985 for references), ostracods (Tesakova et al., 2005), trace fossils (Gorbachik et al., 1970; Yanin and Baraboshkin, 2010), brachiopods (Smirnova, 1962; Lobacheva and Smirnova, 2006), bivalves (Yanin and Smirnova, 1981) and palynology (Kuvaeva and Yanin, 1973).

Considering the shortcomings of the ammonite record in Crimea, and the effective biostratigraphic application of calpionellids in numerous other Tethyan sections, only limited use had been made of them in Crimea before our study (Linetskaya, 1968, 1969; Sazanova and Sazanov, 1984), and, apart from initial limited sampling (Matveev, 2009; Matlaj, 2011), the same is true of calcareous nannofossils. Some recent accounts present calpionellid results (Platonov et al., 2014) which do not match those from studies in Tethys (see below), and their tying of magnetostratigraphy to calpionellid zones is not compelling, for instance: the Chitinoidella/Crassicollaria zonal boundary lying in M19.2n (misnumbered "19n.1r"), the base of the Alpina Subzone within M18r, nor the base of the Jacobi Subzone coinciding more or less with the base of magnetozone M18r (nor is the base of the Alpina Subzone exactly equivalent with the base of the Jacobi Subzone, as in Arkad'ev, 2016). 


\section{THEODOSIA LOCALITIES AND LITHOSTRATIGRAPHY}

In central Crimea, in the Krasnoselivka road section (valley of the Tonas River), the lowest Berriasian (?Jacobi Subzone) sits with angular unconformity on reefal limestones of presumed Tithonian age (Arkad'ev et al., 2005). But in eastern Crimea no such sharp lithological change and marked break is seen: close to Theodosia the $\mathrm{J} / \mathrm{K}$ boundary lies within a long sequence of, below, alternating darker mudstones and coarse turbiditic limestones (grainstones and rarer rudstones) and, above, pale micrite and marl-dominated sediments. For many years the Tithonian/Berriasian boundary was placed at the level of the major breccia bed, already mentioned (Muratov, 1937; Druschits, 1975), within the dark mudstone and grainstone sequence.

The coastal sections at the eastern end of Dvohyakirna Bay, around the headland of Ili Burnu and thence northward along the coast to the town of Theodosia show a thick development of the top Tithonian to lowest Berriasian, very thick compared to western Tethyan sections. The Jacobi and Grandis subzones alone here amount to $>160 \mathrm{~m}$. The sequence dips mostly to the north, and is terminated at its northern end in beds which extend no higher than the Pseudosubplanites grandis Subzone. The section is characterized by a paucity of macrofossils: occasional aptychi and ammonites, rarer bivalve beds, thick mudstones and lensing coarse grainstones (with ubiquitous horizontal burrow systems) and breccias all point to an offshore distal slope setting, with predominant quiet fine-grained sedimentation punctuated by injections of coarser mass flows, with debris exceptionally up to boulder-size.

Druschits (1975) was the first to pay attention to a total succession near Theodosia, and he gave an illustration of more than one hundred metres of presumed Berriasian beds on the coast, in a frequently quoted account. The succession he portrayed is a composite, including, at its base, the section west of Ili Burnu, as well of those nearer to Theodosia, and also intervals that cannot currently be identified or located. In more recent times, in a series of publications, Bogdanova and Arkad'ev (2005) have returned to consideration of ammonites from the Theodosia coast; and, latterly, Arkad'ev has published several works on ammonites in combination with magnetostratigraphy (Guzhikov et al., 2012; all works referenced and summarized in Arkad'ev et al., 2012)

Between the town of Theodosia and the headland of Ili Burnu and then westward into Dvohyakirna Bay the succession is cut repeatedly by small normal faults, and in places crumpling and disruptive small-scale low-angle faults occur. Between extensive outcrops, much ground is obscured, with little or no exposure, which makes it difficult to measure a continuous sequence. But it is possible, with care, to create a composite succession from the multiple outcrops. The entire succession with contrasting lithologies, dark mudstones below and micrites and marls above, was previously combined in a single formation, the Dvuyakornaya Formation (Permyakov et al., 1984). Herein we separate these two differing lithologies. Broadly, in Dvohyakirna Bay (except for the cliff tops) most outcrops show the lower beds, the Dvuyarkornaya Formation (Figs. 1: sections 1-6 and 2), seen up to the major fault $250 \mathrm{~m}$ NW of Ili Burnu. Thereafter, outcrops mostly show the overlying Mayak Formation (new formation name; Fig. 3).

Most attention in past accounts has been given to the ammonite-bearing Berriasian limestone/marl beds at Theodosia, so this account will start there and work down the stratigraphic succession.
MAYAK FORMATION

Locally, the formation is stratigraphically the highest, though its top is not exposed. It is seen in four substantial cliff sections (Fig. 1, localities A, B, C and D), and lesser intermediate exposures. The cliff below the lighthouse at Ili Burnu, to outcrops $1 \mathrm{~km}$ to the west (A and D), shows the boundary between the mudstone and grainstone-dominated Dvuyakornaya Formation and the overlying Mayak Formation.

At the Ili Burnu lighthouse cliff $\left(45^{\circ} 00^{\prime} 44.70^{\prime \prime} \mathrm{N}\right.$, $35^{\circ} 25^{\prime} 20.74$ " E), the Mayak Formation consists of nine groups of hard micrite beds in a sequence of marls and mudstones, and minor grainstones. Here only the lowest part of the formation crops out, totalling $21 \mathrm{~m}$ in thickness (all those beds above the highest thick grainstone of the Dvuyakornaya Formation; Fig. 3). Several metres more above are obscured. This micrite/marl interval has been consistently recorded with a thickness of $13 \mathrm{~m}$ (member 23 of Arkad'ev et al., 2006, 2012) and having five "marl" beds. This cliff section has been quoted as showing Retowski's (1894) "Feodosia Marl", and has even been described as his original ammonite locality (e.g., Bogdanova and Arkad'ev, 2005). This sequence (pale micritic limestone, clayey micrites and marl alternations, and rare, green, soapy mudstones, and minor microbreccia levels) is herein given a new name, the Mayak Formation.

This is to distinguish these pale beds from the markedly different, dark and medium-grey mudstones (and numerous thicker grainstones/breccias) of the underlying Dvuyarkornaya Formation. We reserve the older name Dvuyakornaya Formation only for the mudstone and grainstone/breccia interval beneath (Fig. 2). Ili Burnu is here defined as the type section for the Mayak Formation, a unit typified by micrite/marl alternations (Fig. 3).

The cliff-top section at the Ili Burnu lighthouse yields ammonites at several levels, but few other fossils. Northwards, the same Mayak Formation beds are seen intermittently in gullies and in smaller cliffs, but it is less easy to outline a succession. Elements of the same formation are clearly seen $\mathrm{N}$ of "Smuggler's Bay" (Kontrabandist Bukhta - local name). Then, $1 \mathrm{~km}$ north of the lighthouse, a clean outcrop shows higher beds in the formation, on the shore and in an unnamed, vertical sea cliff - our "Middle Cliff" (Fig. 1, locality B). Finally, $1.5 \mathrm{~km}$ to the north of Ili Burnu, and immediately south of Theodosia $\left(45^{\circ} 01^{\prime} 22.75^{\prime \prime} \mathrm{N}, 35^{\circ} 25^{\prime} 42.55^{\prime \prime} \mathrm{E}\right)$, another cliff shows the highest accessible parts of the formation (Fig. 1, locality C) with higher units concealed beneath the town. This last locality was previously described by Glushkov (1997). The Theodosia boathouse section dips to the south and consists of eleven thicker micrite units between marls (Fig. 3), to a thickness of $>30 \mathrm{~m}$. Some distinctive marker beds in Glushkov's account, notably three massive sparitic grainstone units, can be readily identified. Above is a further, less well-exposed, interval (estimated at $>6 \mathrm{~m}$ ) made up of predominant thicker marls and mudstones and lesser limestones.

The lower Mayak Formation at Ili Burnu has a distinctive and, compared to lower levels, a relatively common ammonite fauna (with, of stratigraphically useful forms, several species of Delphinella, Dalmasiceras subloevis Mazenot, Retowskiceras and small spiticeratids). However, the section in the highest exposed beds of the Mayak Formation (Fig. 1, locality 3) immediately south of Theodosia has a different relatively common fauna dominated by large Pseudosubplanites. Four species of Pseudosubplanites were recorded there by Glushkov (1997), including, significantly, $P$. grandis, as well as long-ranging lytoceratid and phylloceratid taxa, but no Berriasella. The identification of $P$. grandis can be confirmed with certainty, as well as 


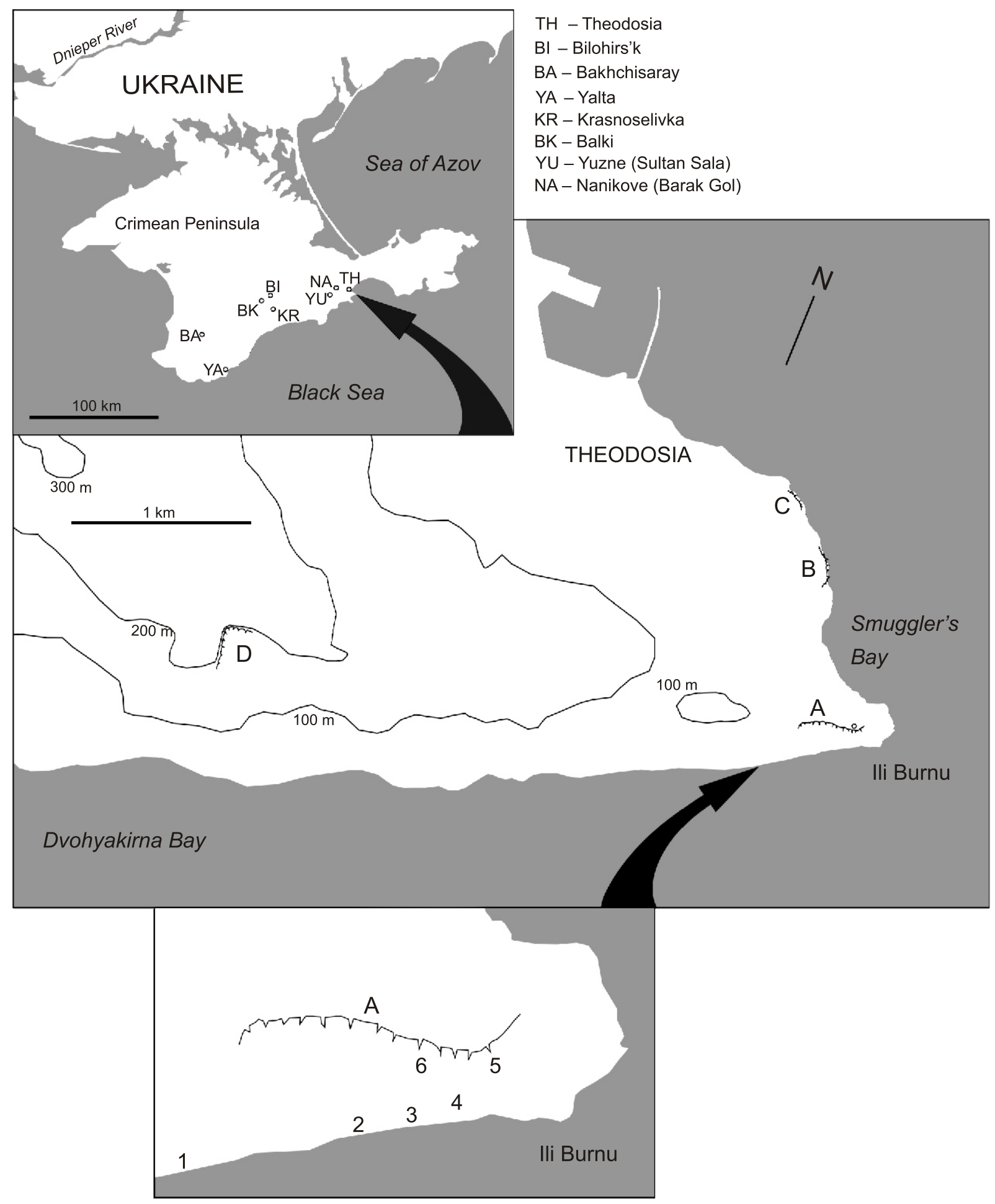

Fig. 1. Locality maps for Tithonian-Berriasian profiles south of Theodosia (localities A-D and 1-6)

Dvuyakornaya Formation profiles are (informal names): 1 - Breccia section, 2 - Gulley section, 3 - Path section, 4 - Step section, 5 - East-facing cliff, 6 - in the main cliff pediment, the Lighthouse shack section; Mayak Formation profiles are: A the Lighthouse cliff, B - the "Middle Cliff", C - the Boathouse Cliff 


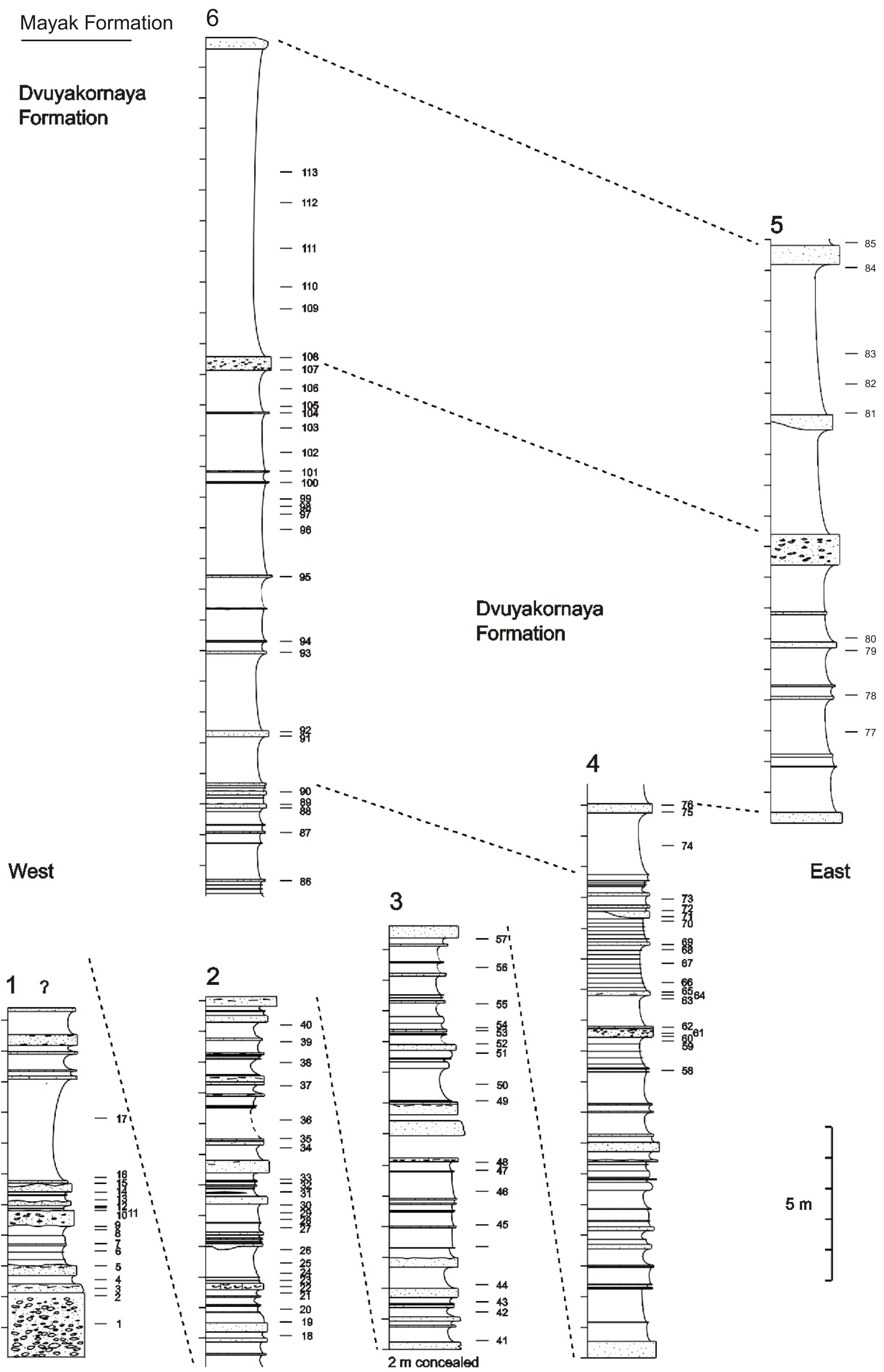

Fig. 2. Dvuyakornaya Formation profiles in the upper cliff pediment, and in the beach and foreshore cliffs at Ili Burnu (localities 1-6), with micropalaeontological sampling points

Dotted ornament indicates grainstones and fine breccias: intermediate beds are mudstones, medium to dark grey 
Ili Burnu Cliff (A)

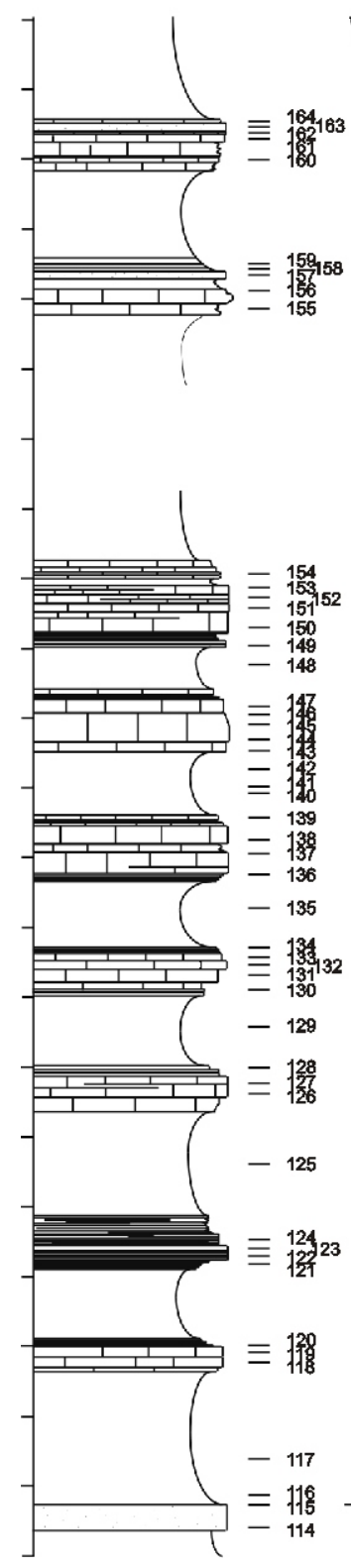

Boathouse Cliff (C)

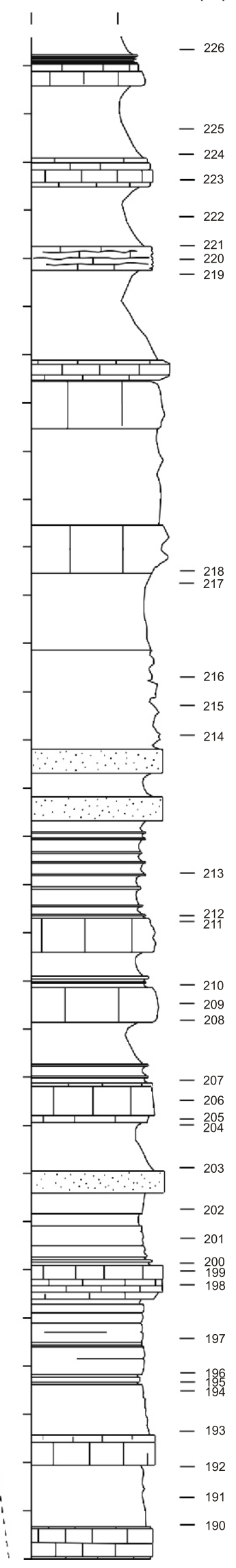

Fig. 3. Mayak Formation profiles between Ili Burnu and Theodosia (localities A-C), with micropalaeontological sampling points 
$P$. berriasensis; and the ammonite fauna thus indicates the Grandis Subzone. Published accounts in recent years have overlooked Glushkov's (1997) boathouse-cliff assemblage, as far as its true stratigraphic and geographical positions are concerned.

Half a kilometre south of the cliff figured by Glushkov (1997) is our "Middle Cliff" $\left(45^{\circ} 01^{\prime} 16^{\prime \prime} \mathrm{N}, 35^{\circ} 24^{\prime} 53^{\prime \prime} \mathrm{E}\right)$ that exposes the middle units of the Mayak Formation. Two thicker breccias are prominent just above shore level, the lower with a maximum thickness of $1.7 \mathrm{~m}$. But these and other grainstones higher up are only a subsidiary part of a micrite-dominated succession. Lower beds can be examined closely on the shore, to a thickness of $>20 \mathrm{~m}$, but the upper part of the cliff above the two breccias, is largely inaccessible. Though fourteen thicker micrite units, alternating with marls and mudstones, are traceable. The very top part of the cliff is comparable to the Glushkov (1997) cliff, and continuity can be confirmed visually from seaward. This large Middle Cliff outcrop has been illustrated (Guzhikov et al., 2012), but shown as equivalent to the lowest part of the shore cliffs at Ili Burnu, that is, to the Dvuyakornaya Formation (actually to a level $\sim 75 \mathrm{~m}$ below the base of the Mayak Formation; Guzhikov et al., 2012: fig. 2d, base of member 10). However, the thick breccia that crops out here lies in the middle of the Mayak Formation and it is, stratigraphically, $>100 \mathrm{~m}$ above the $2 \mathrm{~m}$ breccia marker bed on the south side of the lli Burnu headland. Figure 3 shows the Mayak Formation profiles below the Ili Burnu lighthouse and northwards towards Theodosia.

The attribution of ammonites from the Mayak Formation in Russian publications and on museum collection labels is variously to "Feodosiya", "Mis Il'i" or "Cape St. Elias", i.e. to several kilometres of coastal outcrops, making assignments of museum specimens to precise outcrops and horizons difficult. Earlier, Bogdanova et al. (1984) recorded Pseudosubplanites commonly at Nanikove, in the Yuzhne section (only in the topmost bed), but not at all from the Ili Burnu cliff ("Mis Il'i"). Latterly, Arkad'ev (in Arkad'ev et al., 2012) has recorded the genus at Ili Burnu, including $P$. grandis. In this study, search in the lighthouse cliff beds has not revealed any specimen of Pseudosubplanites grandis. The published citations of Pseudosubplanites (and other taxa) in all sections in the district need clarification, as finds from Ili Burnu, Glushkov's Boathouse section, unlocalised "Feodosiya" occurrences, as well as Yuzhne, have been conflated to such a degree that the facts of bed and locality provenance are very uncertain.

\section{DVUYAKORNAYA FORMATION}

On the south side of Ili Burnu, below the upper cliff in the Mayak Formation, outcrops are in very different lithologies: micrite beds are few, and most limestones are hard intrasparites, microbreccias and breccias (grainstones/rudstones) in thicker mudstone units (Fig. 2). These beds form the Dvuyakornaya Formation (Permyakov et al., 1984), here redefined. Whereas Mayak Formation micrite units are traceable over considerable distances, the breccia and intraclastic grainstone units of the Dvuyakornaya Formation sometimes lens markedly, and a seemingly useful and consistent thick marker bed may diminish to a centimetre or less in just a few metres.

The Dvuyakornaya Formation forms the cliff pediment and shore cliffs south of Ili Burnu, and to the west, on the coast and inland. At Ili Burnu several separate outcrops occur at shore level, affected by small-scale faulting, and the lowest stratigraphically, is bottomed by the massive $2 \mathrm{~m}$ thick breccia already mentioned (Fig. 2, section 1). From the base of this breccia to the base of the Mayak Formation measures $\sim 80 \mathrm{~m}$.
Kuznetsova and Gorbachik (1985), recording Berriasian foraminifera from "Theodosia", sampled seven horizons in the slopes here, but, apart from the massive breccia bed, it is not clear precisely which levels were collected (or where) in the Dvuyakornaya Formation (or the Mayak Formation). Further outcrops in the Dvuyakornaya Formation existed just north of the headland, but these have been buried or destroyed by recent development.

Looking at the stratigraphic synthesis given by Druschits (1975), and allowing for discrepancies in thickness, it appears that his units 7 to 9 may be the equivalent of the $30 \mathrm{~m}$ plus Theodosia boathouse-cliff section and that the $21 \mathrm{~m}$ thick lighthouse-cliff micrites equate to some part of his unit 5 and 6 . But there appears to be no space in Druschits, column below to accommodate the upper Dvuyarkornaya Formation (80 $\mathrm{m}$ in thickness), that part which falls between the base of the Mayak Formation and the $2 \mathrm{~m}$ breccia (unit 2 of Druschits); and his account shows a section above the basal breccia that, from bottom to top contains Pseudosubplanites, which is incorrect. However, the base of the limestones of the Mayak Formation and the massive breccia constitute two useful datums.

\section{AMMONITE BIOZONES}

Upper Tithonian finds from west of lli Burnu have already been mentioned. In the upper Dvuyakornaya Formation ammonites are rare, and the patchy distribution of stratigraphically useful species means that no coherent ammonite zonal scheme can be constructed for the lowest Berriasian. Though Berriasella jacobi [Strambergella jacobi] has been described in the Tonas valley (central Crimea), none has been found in the east. One species of Berriasella, " $B$. chomeracensis" and one specimen of Fauriella cf. floquinensis have been recorded, at shore level just west of lli Burnu, a little above the massive breccia (Arkad'ev and Bogdanova, 2004; Fig. 1, section 1): these finds were assigned to the Jacobi Subzone.

The lowest Mayak Formation at lli Burnu has an ammonite assemblage that is dominated by Delphinella species, though this fauna has been assigned to the Grandis Subzone by Arkad'ev et al. (2006, 2012) and listed as: Pseudosubplanites grandis (Mazenot), P. combesi (Le Hégarat), P. ponticus (Ret.), $P$. Iorioli (Zit.), Delphinella subchaperi (Ret.), D. crimense (Burkh.), D. obtusenodosa (Ret.), D. tresannensis Le Hegarat, $D$. janus (Ret.), D. pectinata Ark. \& Bog., and Berriasella berthei (Toucas). In France, Berriasella berthei, $P$. ponticus and $P$. lorioli have been described as ranging though both the Jacobi and the Grandis subzones (Le Hégarat, 1973), whereas Delphinella subchaperi, $D$. crimense, $D$. obtusenodosa and $D$. tresanensis were reported to be limited to the Jacobi Subzone. It seems that none of the macroconch Pseudosubplanites ( $P$. grandis, $P$. combesi, $P$. berriasensis) occurs in the lowest Mayak Formation at Ili Burnu. Our collecting confirms this: in the lower Mayak Formation we found a predominance of Delphinella species (D. crimense, D. obtusenodosa etc., but not $D$. subchaperi), with Retowskiceras andrusovi, Dalmasiceras subloevis, P. lorioli, and Negreliceras obliquenodosum (Ret.) - an assemblage normally assigned to the Jacobi Subzone of past authors. Strambergella jacobi has not been collected, and nor has the basal Berriasian Elenaella cularensis (see Wimbledon et al., 2013; Frau et al., 2016).

The middle part of the Mayak Formation is still under study, though we can record Retowskiceras andrusovi from it. An ammonite assigned (Guzhikov et al., 2012: p. 271) to Delphinella cf. tresanensis was regarded as indicative of the Berriasella Jacobi Subzone: it was thought to come from be- 
neath the prominent $2 \mathrm{~m}$ breccia in the Dvuyakornaya Formation (Fig. 1, section 1). However, the ammonite came from the middle Mayak Formation, from immediately below the $1.7 \mathrm{~m}$ breccia bed in the "Middle Cliff", between Ili Burnu and the Theodosia boat houses (Figs. 1, locality B and 3).

As stated, the highest exposed parts of the formation immediately adjacent to Theodosia yield large Pseudosuplanites. Though Glushkov's first record of $P$. grandis in Ukraine has been repeatedly cited, and his specimen several times refigured (e.g., Arkad'ev et al., 2012), it has been stated, erroneously, to have come from the lighthouse cliff at Ili Burnu ("Cape Svyatogo Il'i, Section 4, Member 23"), and thus the bottom of the formation.

\section{PALAEOMAGNETISM}

\section{SAMPLING AND LABORATORY METHODS}

A representative collection of samples have been made over three field seasons. We started with a pilot collection, to make the necessary measurements that constrain the positions of the geomagnetic polarity zones, followed by additional sampling to gain higher precision. We paid attention to the more problematic levels where the palaeomagnetic data was complicated, taking extra samples, with a sampling density of about every $10 \mathrm{~cm}$ : whereas the average sampling interval was $\sim 30 \mathrm{~cm}$. The above-described economical collecting strategy finally yielded 282 orientated samples, which were drilled or collected as hand samples from dark and medium-grey mudstones, breccias, micritic limestone, and clayey micrites and marl. The natural remanent magnetization (NRM) of the rocks is too small to affect the compass needle. The orientations of the beds, with dip angles of $10 \pm 9^{\circ}$, were unfavourable for a successful fold-test to be applied to the NRM directions.

Palaeomagnetic measurements were carried out in the laboratory of the Institute of Geophysics of the National Academy of Sciences of Ukraine in Kyiv. Specimens in the form of cylinders $(2.2 \mathrm{~cm}$ in length) or cubes $(2.0 \mathrm{~cm}$ square) were cut (2-4 specimens from each sample). Standard palaeomagnetic experiments were performed, consisting of the measurement of NRM of specimens in their original state and, after each demagnetization step, during alternating field (AF) and stepwise thermal (TD) procedures. The vectors of characteristic remanent magnetization (ChRM) were isolated by both TD and $\mathrm{AF}$ demagnetization. The procedures for the demagnetization of specimens (thermal and alternating field) and all measurements were made inside magnetically shielded rooms, to minimize the acquisition of present-day viscous magnetization.

Specimens were stepwise thermally demagnetized using an MMTD80 up to $600^{\circ} \mathrm{C}$. After each heating step, the magnetic susceptibility $(k)$ was measured at room temperature with a MFK1 Kappabridge, to monitor possible mineralogical changes. Duplicate specimens were subjected to AF demagnetization up to $100 \mathrm{mT}$ using a $L D A-3 A$ demagnetizer. Demagnetization steps were adjusted during thermal or $A F$ procedures from 10 to $50^{\circ} \mathrm{C}$ and $10-20 \mathrm{mT}$, respectively. The NRM of specimens was measured with a JR- 6 spin magnetometer with a sensitivity of $2.4 \mu \mathrm{A} / \mathrm{m}$. Duplicate specimens were subjected to AF demagnetization using a $L D A-3 A$ demagnetizer, and these results used to confirm the thermal demagnetization data. For verification of the demagnetization results, a few specimens with low NRM intensity were measured in the palaeomagnetic laboratory of the Institute of Geophysics of the Polish Academy of Science, Warsaw (using a 2G SQUID DC magnetometer accompanied by an AF demagnetizer).
Demagnetization results were processed by multicomponent analysis of the demagnetization path (Kirschvink, 1980), using Remasoft 3.0 software (Chadima and Hrouda, 2006). Anisotropy of magnetic susceptibility (AMS) was measured on all samples with a MFK-1 Kappabridge, and magnetic anisotropy parameters were calculated with the Aniso programme (Jelínek, 1973).

In order to assess the magnetic mineralogy of samples, hysteresis characteristics, $I_{\mathrm{s}}(T)$ and $k(T)$ thermomagnetic curves were measured on a few mudstone samples (in the Institute of Geophysics in Warsaw).

\section{THE NRM AND BULK MAGNETIC SUSCEPTIBILITY}

Before the magnetic susceptibilities and NRM values of specimens are shown plotted against the sample level (see below), we present histograms which show their variations in different types of mudstones (Fig. 4A) and other rocks - limestone breccias, coarse limestones, micrites, etc. - herein simplified to the convenient term "limestone" (Fig. 4B).

The mudstones are characterized by a wider spread of the above-mentioned magnetic parameters. The average values are $0.5 \mathrm{~mA} / \mathrm{m}$ for NRM and $200 \times 10^{-6} \mathrm{SI}$ for magnetic susceptibility. The NRM values of "limestone" are basically the same, but magnetic susceptibilities are significantly lower (average value is $\sim 50 \times 10^{-6} \mathrm{SI}$ ). Through the succession as a whole, with contrasting lithologies, these values are greater in the lower part (Dvuyakornaya Formation) than the upper (Mayak Formation). The same feature was noted in the vicinity of the $\mathrm{J} / \mathrm{K}$ boundary at Brodno and in the Bosso Valley (Houša et al., 1999, 2004), in the Tatra Mountains (see Grabowski and Pszczółkowski, 2006), in the Puerto Escaño section in Spain (Pruner et al., 2010) and in SE France (Wimbledon et al., 2013).
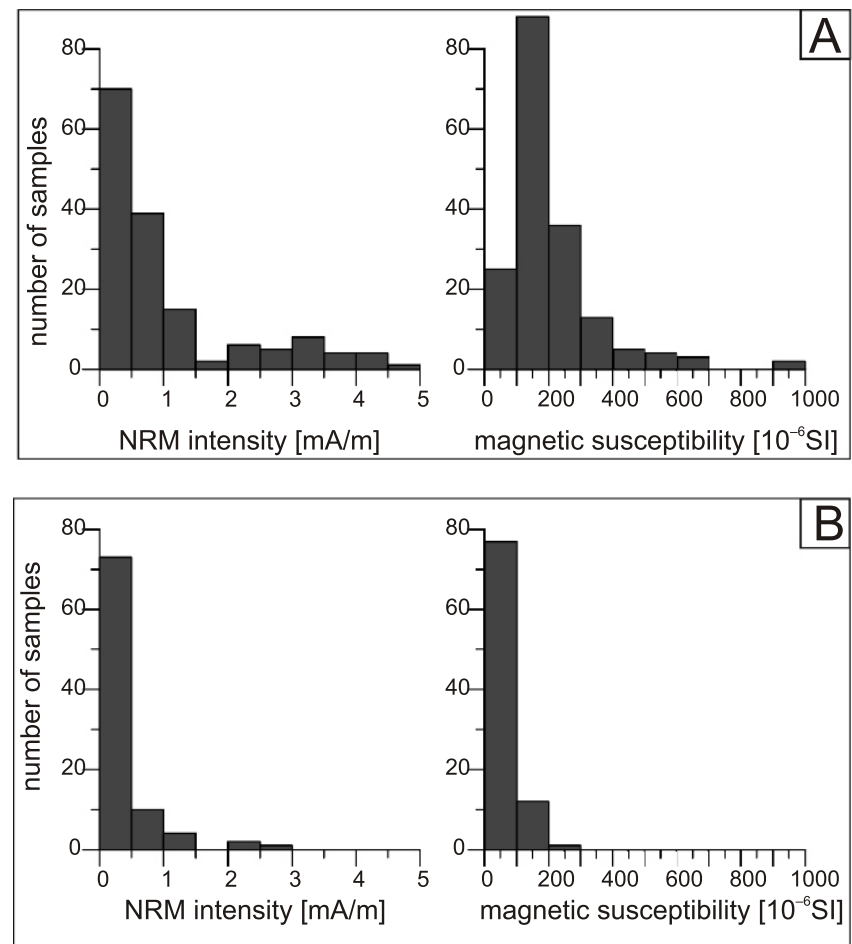

Fig. 4. Histograms of NRM intensity, magnetic susceptibility of mudstone (A) and other rocks: coarse limestone, micritic limestone, clayey micrites, minor grainstones, and marls (B) 
IDENTIFICATION OF MAGNETIC MINERALS AND THE SIGNIFICANCE OF THE NRM COMPONENTS

The demagnetization of pilot samples showed that progressive thermal stepwise demagnetization (15-20 steps to $580-600^{\circ} \mathrm{C}$ ) gave better results than AF stepwise demagnetization.

Figure $5 \mathrm{~A}$ shows an example of a thermally demagnetized limestone which above $200^{\circ} \mathrm{C}$ showed the reverse polarity component: whereas, after AF demagnetization, $~ 30 \%$ of NRM still remains demagnetized and specimens show a normal polarity component (Fig. 5B).

In another example (Fig. 5C, D), both $\mathrm{AF}$ and thermal stepwise demagnetization of micrite specimen show reverse polarity after removal of the viscose component $\left(200^{\circ} \mathrm{C}\right.$ and $20 \mathrm{mT}$ respectively).

Thermal demagnetization of mudstone samples showed pronounced decay of the remanence between $\sim 200$ and $400^{\circ} \mathrm{C}$, and increasing magnetic susceptibility $>420-450^{\circ} \mathrm{C}$ (Fig. $5 \mathrm{E}$ ). Some samples show a small plateau after $200^{\circ} \mathrm{C}$ (Fig. 5F) and, gradually, demagnetization in the temperature range 300 to $520^{\circ} \mathrm{C}\left(580^{\circ} \mathrm{C}\right)$. The results from mudstone specimens usually look more informative than for other rock types, with less scatter between demagnetization steps at high temperatures and conformity with the results of neighbouring samples.

Multicomponent analysis of demagnetization paths reveals that the NRM of the samples is composed of two or three components. The low stability component (LTC) was erased in the temperature range $20^{\circ} \mathrm{C}$ to $160-200^{\circ} \mathrm{C}$ or an $\mathrm{AF}$ field in the interval 10-20 mT (Fig. 5). The intermediate stability component (ITC) in the temperature range of $200^{\circ} \mathrm{C}$ to $320-360^{\circ} \mathrm{C}$ (see, for example, Fig. 5D) is not displayed in most samples. During AF demagnetization the intermediate coercivity component was manifested only in some samples. The most stable high-temperature components (HTC) in a temperature range between 300 and $520^{\circ} \mathrm{C}\left(580^{\circ} \mathrm{C}\right)$ are towards to the end point on the orthogonal projections for most of the specimens (Fig. 5A, D-F) and accepted as a characteristic component of NRM (ChRM) For many specimens the high coercivity components (HCC) even in high values of AF demagnetization are not going to the end point of the orthogonal projections (Fig. 5B, C).

Identification of magnetic minerals and timing of remanent acquisition is one of the important criteria in any palaeomagnetic investigation. Experiments on magnetic mineralogy, including analyses of thermomagnetic curves $d l_{s}(T) / d T$ and hysteresis parameters (such as remanent coercive force $H_{\mathrm{cr}}$, and remanent saturation magnetization $I_{\mathrm{rs}}$ ) have been carried out on a number of samples from the same area (Guzhikov et al., 2012). The main NRM carrier in the studied rocks was identified as magnetite, grains of which were partially oxidized to maghemite. A few samples show the presence of a hard coercivity mineral (probably hematite).

The results of these confirm the presence of magnetite as a main carrier of magnetization, and partially the presence of hematite, which could be an authigenic secondary mineral formed during subsequent diagenesis. Thus we can explain the main features and peculiarities of the AF and thermal demagnetization curves: unblocking temperatures varying mostly from 300 $\left(360^{\circ} \mathrm{C}\right)$ to $520\left(580^{\circ} \mathrm{C}\right)$ are due to magnetite, and the high coercivity component in some specimens is due to hematite.

For the analyses of the directions of NRM-components we prefer the TD data because some of the samples are not demagnetized even in high alternating fields. In these cases the ChRM components after AF and TD demagnetizations show controversial directions (cf. results in Fig. 5A, B). The mean direction of the LTC-component is close to the direction of the present-day geocentric axial dipole field $\left(63^{\circ}\right)$, which may have been introduced by recent growth of viscous remanence (Fig. 6A). ITC-components mostly have directions that indicate a geomagnetic field with normal polarity, but $\sim 10 \%$ of samples show reversed polarity (Fig. 6B). The mean direction is $\mathrm{D}^{\circ}=354.7 ; 1^{\circ}=54.4$, which suggests that this component acquired in the Cenozoic - some samples with reversed polarity have the lowest unblocking temperature and reflect the directions of the HTC-component.

The HTC-component has normal and reversed polarity directions. On the stereographic projections we present the directions of the HTC-component separately for mudstones (Fig. 6C) and limestones (Fig. 6D). As was mentioned above we accept the results from mudstone as more informative than the other lithologies for the allocation of HTC-component directions (Table 1).

For comparison of the palaeomagnetic direction of mudstones and limestones, the data of HTC-components (Fig. 6C, D) were transposed to unit polarity. The parameters (after tilt correction) are: for mudstones, $n=190$; $\mathrm{D}^{\circ}=315.4$; $1^{\circ}=47.5 ; k=5.1 ; \alpha_{95}{ }^{\circ}=5.0 ;$ and for limestones, $n=74 ;$ $\mathrm{D}^{\circ}=323.1 ; \mathrm{I}^{\circ}=46.5 ; k=3.1 ; \alpha_{95}{ }^{\circ}=11.2[n-$ number of samples which yielded the HTC-component; $D^{\circ}$ - declination; $I^{\circ}-$ inclination; $k$ - estimate of Fisher's (Fisher et al., 1987) precision parameter; $\alpha_{95}{ }^{\circ}$ - half-angle of cone of $95 \%$ confidence, in degrees]. The mean palaeomagnetic directions are very similar, despite the differences in lithology of the samples.

Data on the anisotropy of magnetic susceptibility (AMS) for mudstones and limestones show differences in their ellipsoid axes directions (Fig. 7). The mudstones are characterized by oblate ellipsoids with well-grouped minimum axes (K3) close to the normal of the bedding planes. The maximum axes of ellipsoids have a predominant SE-NW orientation (Fig. 7A). The parameter of degree of anisotropy, $\mathrm{P}$, is mostly $<1.1$ (mean 1.05), and Flinn diagrams show the "oblate" shapes for AMS ellipsoids, which is typical for undeformed or weakly deformed terrigenous sediments. It suggests that the sedimentary/compactional fabric is preserved in these samples, and that they could be a good candidate for separation of the primary component of ChRM. On the other hand, the direction of the NRM for mudstones could be affected by "inclination error" due to compaction after sedimentation.

The AMS of limestones should be less affected by inclination shallowing if authigenic magnetic grains are partial carriers of NRM. The limestones (Fig. 7B) are characterized by a lower degree of anisotropy, $\mathrm{P}$ not exceeding 1.04 (mean 1.02), and more scatter in the directions of the anisotropy axes (cf. spread of $\mathrm{K} 1$ and $\mathrm{K} 3$ axis directions in Fig. 7A). The mean directions of the AMS ellipsoid axes are not significantly different from the mean directions of mudstones, but Flinn diagrams show the presence of both prolate and oblate ellipsoids of anisotropy. This can be explained by the presence of authigenic magnetic grains which can carry the chemical remanent magnetization, whereas the presence of detrital grains in limestones could have provided the sedimentary fabric and been responsible for the depositional/post-depositional remanent magnetization.

Since the mean palaeomagnetic directions of the HTC-component are similar in mudstones and limestones, we can assume that the difference in the time of the acquisition of the depositional and chemical remanent magnetization is, geologically, not significant, and that the ChRM could have formed during sedimentation or in an early stage of diagenesis.

Thus, the presence of normal and reversed HTC-component (which coincide in lithologically different sediments), the identification of magnetite (partially oxidized to maghemite) as 

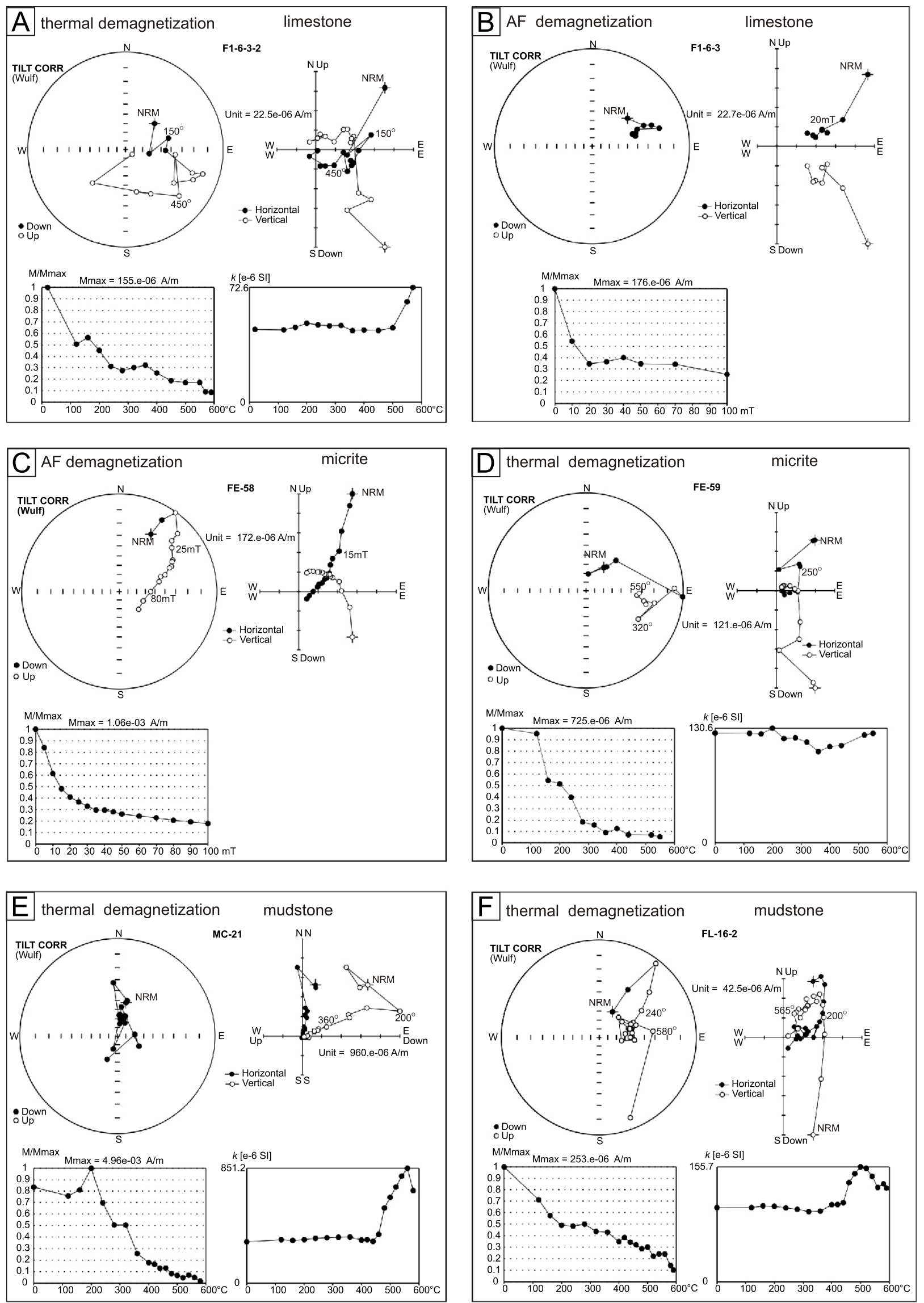

Fig. 5. Plots of the progressive thermal (A, D, E, F) and alternating field (B, C) demagnetization of coarse limestone, micrite and mudstone specimens

Top left diagrams - stereographic projection of the directions (full and open circles represent projections in the lower and upper hemispheres, respectively); top right diagrams - orthogonal projections of demagnetization paths (Zijderveld diagrams) on horizontal and vertical planes; bottom left diagrams - NRM intensity decay during demagnetization (M/Mmax); bottom right diagrams changes of magnetic susceptibility, $k$ during thermal treatment $(A, D, E, F)$; stereographic and orthogonal projections are given after tilt correction 

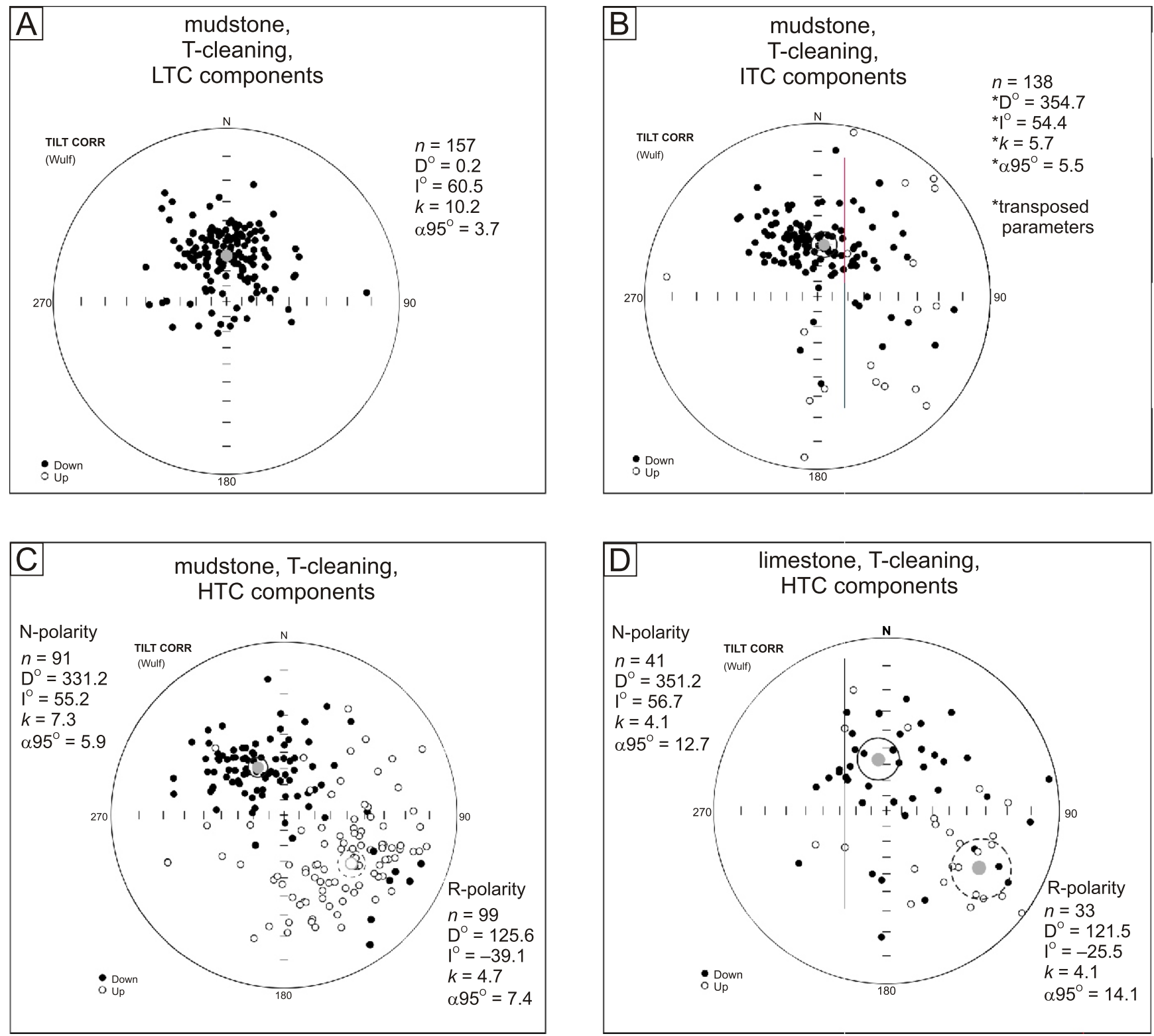

Fig. 6. Stereographic projections of corrected bedding dip directions of the LTC (A), ITC (B) and HTC-components of mudstone (A, B, C) and HTC-components of limestones (D)

Open symbols denote upward- and solid denote downward-pointing inclinations; the mean direction with radius of the $95 \%$ confidence cone and statistic parameters $\left[n\right.$ - number of specimens which yielded the components; $\mathrm{D}^{\circ}$ - mean declination; $I^{\circ}$ - mean inclination; $k$ - estimate of Fisher's (Fisher et al., 1987) precision parameter, $\alpha 95$ - half-angle of cone of $95 \%$ confidence, in degrees] are given for normal and reversed $(C, D)$ polarities

the main carrier of remanent magnetization and the AMS data are weighty arguments in favour of the primary magnetization of the ChRM component. The recent suggestion of pervasive remagnetization of sedimentary rocks in Crimea and the Western Pontides during the Early Cretaceous (Çinku et al., 2013) does not apply to our study area in eastern Crimea.

\section{MAGNETOSTRATIGRAPHY}

To determine a magnetostratigraphic scale, we first of all considered the corrected bedding-dip directions of ChRM as defined in mudstones. The results for limestones were also considered, if their ChRM direction was not in conflict with over- lying and underlying mudstone layers. Figure 8 shows (from the left to right) the scalar magnetic parameters (volume magnetic susceptibility $k$, the modulus of natural remanent magnetization $\mathrm{M}$ ), directions of the ChRM-component (inferred by means of a multi-component analysis and expressed by declination $D^{\circ}$ and inclination $I^{\circ}$ ), discriminant function (the functions of the directions of the remanence ChRM-component) are plotted against the sample level.

For the purposes of classification, we follow the procedure described by Man (2008), using the MPS program (available at http://www2.gli.cas.cz/man). A short description of this procedure with respect to magnetostratigraphy is given by Pruner et al. (2010). 

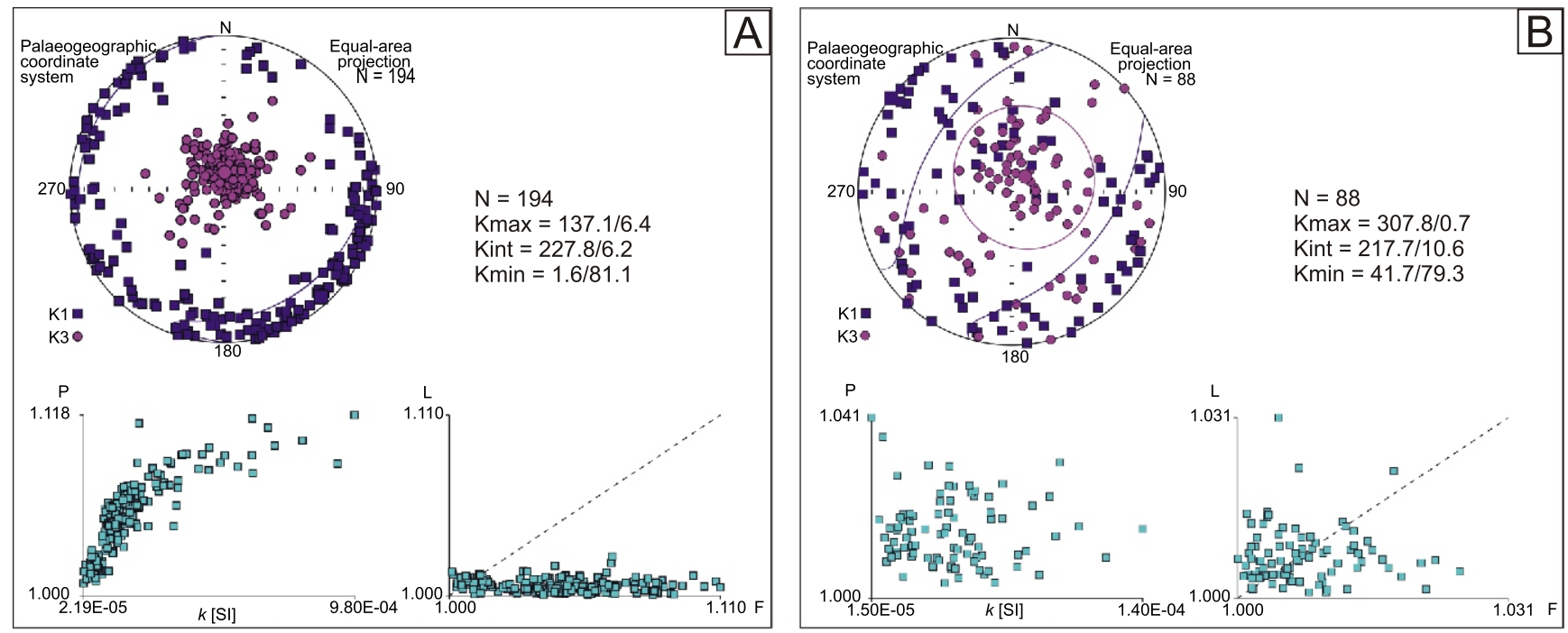

Fig. 7. Plots of anisotropy of magnetic susceptibility directional data on a stereographic projection: $k$ versus $P, F$ versus $L$ (Flinn diagram) for mudstones (A) and limestones (B)

The directions of the maximum principal axes $\mathrm{K} 1$ and minimum principal axis $\mathrm{K} 3$ are presented by squares and circles, respectively. Mean tensor (declination/inclination by Jelínek, 1973 , statistics) and other parameters ( $P=K 1 / K 3 ; k$ - magnetic susceptibility; $L-$ lineation, F - foliation) according to Tarling and Hrouda (1993), N - number of specimens

Table 1

Directions of the particular NRM components of mudstone samples before and after tilt correction

\begin{tabular}{|l|c|c|c|c|c|c|c|c|c|}
\hline \multirow{2}{*}{$\begin{array}{c}\text { Component } \\
\text { of NRM }\end{array}$} & \multirow{2}{*}{$\begin{array}{c}\text { Number of } \\
\text { samples }\end{array}$} & \multicolumn{2}{|c|}{ Directions expressed in geographic coordinates } & \multicolumn{4}{|c|}{ Bedding-tilt corrected directions } \\
\cline { 3 - 12 } & $\mathrm{D}^{\circ}$ & $\mathrm{I}^{\circ}$ & $k$ & $\alpha 95^{\circ}$ & $\mathrm{D}^{\circ}$ & $\mathrm{I}^{\circ}$ & $k$ & $\alpha 95^{\circ}$ \\
\hline LTC & 157 & 354.8 & 63.6 & 12.2 & 3.3 & 0.2 & 60.5 & 10.2 & 3.7 \\
\hline ITC & & & & & & & & & \\
Normal & 125 & 353.5 & 59.9 & 6.7 & 5.3 & 1.3 & 55.8 & 6.4 & 5.4 \\
Reversed & 13 & 135.3 & -30.8 & 4.0 & 23.8 & 136.8 & -36.0 & 4.3 & 22.7 \\
\hline HTC & & & & & & & & & \\
Normal & 91 & 320.6 & 58.1 & 7.3 & 5.9 & 331.2 & 55.2 & 7.3 & 5.9 \\
Reversed & 99 & 124.2 & -40.7 & 4.5 & 7.6 & 125.6 & -39.1 & 4.7 & 7.4 \\
\hline
\end{tabular}

Normal or reverse polarities were assigned to the directions within cones of $95 \%$ confidence, whereas directions beyond these limits were considered as being intermediate. The classification of directions is shown on the right of Figure 8 , by the range $(-1$ to 1$)$ of the discriminant function being partitioned by two vertical lines into three intervals, corresponding (from the left) to reversed, intermediate, and normal polarities. Having omitted the intermediate directions, opposite polarities of the successive samples indicated the borders between successive geomagnetic polarity zones.

In order to enable the conventional classification of our data, a reversal test (after McFadden and McElhinny, 1990) was applied to normal and reversed polarities in mudstones samples. The angular distance between mean directions is $156.5^{\circ}$, and thus the reversal test gives a negative result $\left(\gamma / \gamma \mathrm{c}=23.5^{\circ} / 9.5^{\circ}\right)$, which means that the average directions of normal and reverse polarity are statistically different. We assume that this discrepancy is associated with the superimposition of the primary bipolar component and secondary component of magnetization (ITC).
We infer polarity zones from the discriminant function analysis, and these are expressed in Figure 8 by black (normal) and white (reversed) bars. As the stratigraphic position of the section was inferred from palaeontology, the detected polarity zones could be identified against the Geomagnetic Polarity Time Scale (GPTS; Gradstein et al., 2012).

The presented identification of polarity zones allows us to make an approximate estimation of the rate of sedimentation. These calculations should not be treated as absolute because there are many uncertainties, producing significant errors. The sections contain several gaps, therefore the calculated sedimentation rates are mostly minimum values. The sedimentation rates were estimated using the time-scales of Gradstein et al, (2012), the results are presented in Table 2. The highest values occur within the upper part of the Dvuyakornaya Formation. Sections 4, 5, and 6 are characterized by the highest values of magnetic susceptibility (Fig. 8), which does not contradict the higher rates of sedimentation in this part of the Theodosia sequence. 


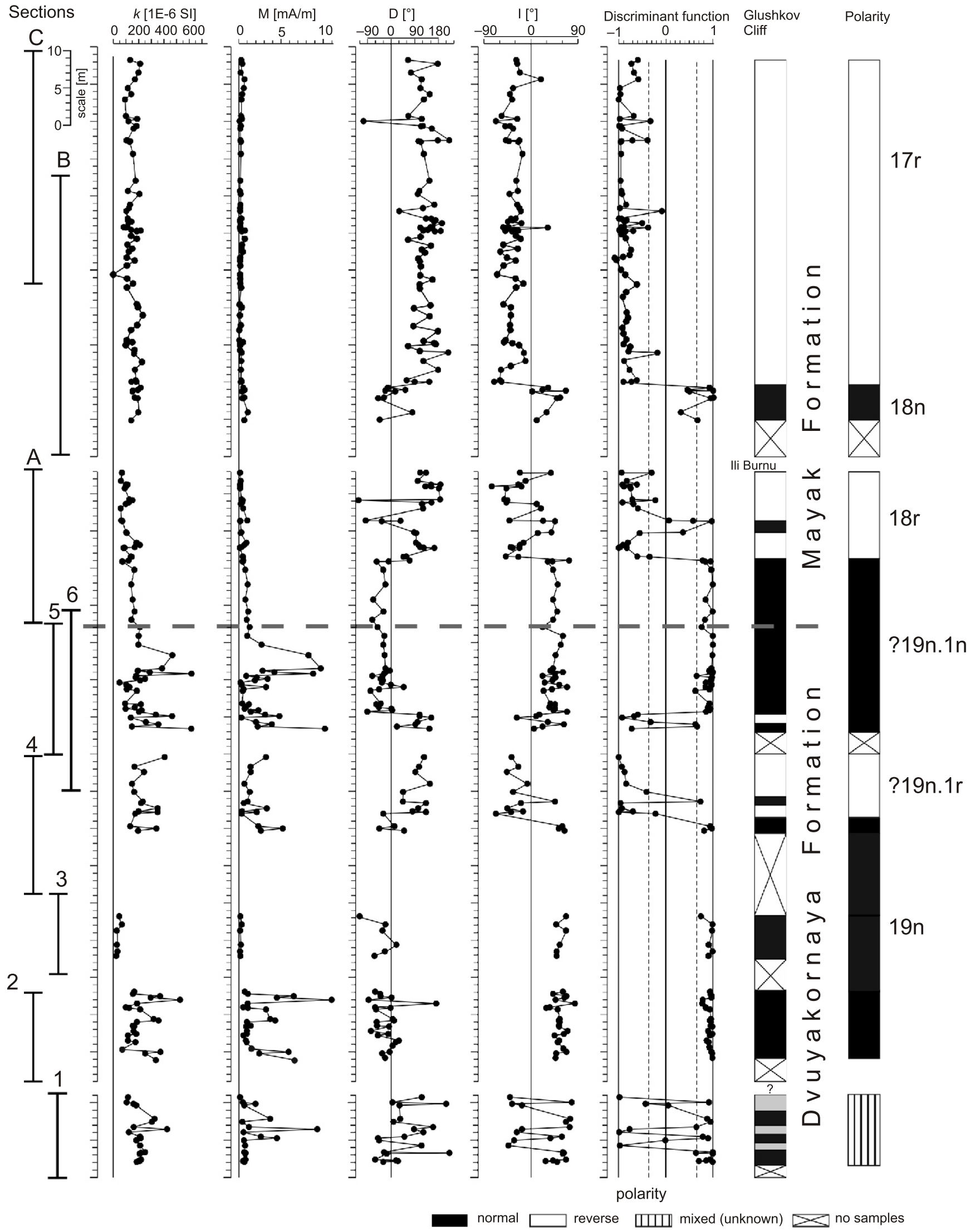

Fig. 8. Palaeomagnetic data plotted through the sections

From the left - the measured values of bulk magnetic susceptibility $(k)$, NRM (M), the direction of the ChRM (determined by the line fitting of the demagnetization path after temperature demagnetization and expressed by declination $\mathrm{D}^{\circ}$ and inclination $I^{\circ}$ ), and the discriminant function of this direction, all plotted against the sample level (or stratigraphic distance). Polarity zones inferred from the discriminant function are expressed by black (normal) and white (reversed) blocks are compared with the corresponding part of the GPTS 2012, against which they have been identified (on the right). The boundary between the Dvuyakornaya and the Mayak formations is represented by a solid line 
Sedimentation rates in the M19-M17 interval in the Theodosia sections

\begin{tabular}{|l|c|c|c|c|}
\hline Magnetozone & Section & Thickness [m] & Duration [my] & $\begin{array}{c}\text { Sedimentation rate } \\
{[\mathrm{m} / \mathrm{my}]}\end{array}$ \\
\hline M17r & C, B & 43 m or more & $\begin{array}{c}1.44 \\
(142.57-144.04)\end{array}$ & 30 or more \\
\hline M18n & B & 5 m or more & $\begin{array}{c}0.63 \\
(144.00-144.64)\end{array}$ & 8 or more \\
\hline M18r & A & 12 m or more & $\begin{array}{c}0.37 \\
(144.64-145.01)\end{array}$ & 32 or more \\
\hline M19n.1n & A, 6, 5 & 25.5 m or more & $\begin{array}{c}0.13 \\
(145.01-145.14)\end{array}$ & 200 or more \\
\hline M19n.1r & 6,4 & 8 m or more & $\begin{array}{c}0.05 \\
(145.14-145.19)\end{array}$ & 160 or more \\
\hline M19n & $2,3,4$ & 35 m or more & $\begin{array}{c}1.09 \\
(145.19-146.28)\end{array}$ & 32 or more \\
\hline
\end{tabular}

The age and duration of magnetozones are from Marine Magnetic Anomaly Age Calibration (in Gradstein et al., 2012: table 5.4)

\section{MICROFACIES AND MICROPALAEONTOLOGY - MATERIAL AND METHODS}

Microfacies, calpionellids, calcareous dinoflagellate cysts and benthic foraminifera and further accompanying allochems and matrix were studied in thin sections and evaluated under a Leica DM 2500 optical light microscope. A revised Dunham classification of microfacies (Embry and Klovan, 1971) has been applied in this study. Microfossils and microfacies were documented using a Leica DFC 290 HD camera. Nannofossil identifications were performed on simple smear slides, prepared as follows: (a) a small amount of rock material powdered adding few drops of bi-distillate water; (b) obtained suspension was mounted onto a microscope slide, covered with a slide cover and fixed with Canada Balsam. The smear slides were inspected using a light polarizing microscope, at 1250X magnification and documented using an Infinity 2 camcorder, and measured using QuickPHOTO Camera 2.3 software. All thin sections and smear slides are stored in the collections of the Department of Geology and Palaeontology (Faculty of Natural Sciences), Comenius University, Bratislava.

\section{MICROFACIES AND MICROFOSSILS OF THE DVUYAKORNAYA FORMATION}

The succession of the Dvuyakornaya Formation was studied in four profiles (Fig. 2: 1, 2, 4 and 6). Microfacies, calpionellids and calcareous dinoflagellates of the formation are shown in Figures 9-13.

\section{BRECCIA SECTION}

The first-mentioned set of studied samples (samples 1-15) comes from the middle part of the Dvuyakornaya Formation. It consists of fine-grained (bioclast-intraclast) limestones (grainstones to rudstones), nodules of Cyanophyceae and fragments of litho-clasts (biomicrite wackestones). The matrix is recrystallized and among the bioclasts there are fragments of bivalves (including oysters), ostracods, crinoids, echinoid spines, calcareous sponges, dasycladalean algae, benthic foraminifera - Nautiloculina sp., Coscinoconus sp., Mohlerina basiliensis (Mohler), microencrusters Crescentiella morronensis (Crescenti), Koskinobulina socialis Cherchi and Schroeder, and Bacinella irregularis Radoičić. These bioclasts came from shallow-water palaeoenvironments. Nodules of Cyanophyceae enclose rare fragments of planktonic crinoids of the genus Saccocoma, aptychi, echinoid, foraminifera and algae fragments. No calpionellids or cysts of calcareous dinoflagellate were observed.

\section{GULLEY SECTION}

Samples from this section (samples 18-40) consist of marly limestones, marlstones, clayey marlstones and calcareous clays with more or less distinct lamination. Some of the samples contain laminae of variable thickness rich in litho- and bioclasts (with packstone texture). Fragments of aptychi, ostracods, crinoids, bivalves, sponge spicules and foraminifera: Lenticulina sp., Spirillina sp., Siphovalvulina sp., Protomarssonella sp., Redmondoides sp., Gaudryinopsis sp., Pseudocyclammina lituus (Yokoyama), Paalzowella sp. and microencrusters of Crescentiella morronensis have been identified among the bioclasts. Calpionellids are rare; Crassicollaria parvula Remane, Cr. brevis Remane, and Cr. cf. massutiniana (Colom), Calpionella alpina Lorenz were observed, mostly enclosed in small micrite clasts. In sample $23, \mathrm{Cr}$. parvula was enclosed in a Cyanophyceae nodule. Calcareous cysts are represented by Cadosina semiradiata semiradiata (Wanner), Cad. semiradiata cieszynica (Nowak), Colomisphaera sublapidosa (Vogler), Col. lapidosa (Vogler), Stomiosphaerina proxima Řehánek and St. $\mathrm{sp}$. Calpionellids and dinoflagellate cysts present are those of the Late Tithonian Crassicollaria Zone. This type of sedimentation is typical for the slope facies zone, whereas the grainstones and rudstones mentioned above suggest toe-of-slope facies zone (Einsele, 1991; Flügel, 2004).

The matrix of pelagic marlstones and clayey sediments mentioned above is composed predominantly of calcareous micrite, locally penetrated by abundant growths of Frutexites Maslov giving a dendrolite fabric. These matrices are dark, probably caused by ferromanganese oxide. Frutexites is a common component of deep-water stromatolites. It preferred oxygen deficient, low-energy environments. The matrix is locally rich in pyrite (framboidal) and organic matter what also indicates oxygen-deficiency. Pyrite occurs as nested accumulations and locally it impregnates bioclasts. Locally, frequent, small, coalified plant fragments and silt-grade quartz grains or muscovite and, not so frequent, glauconite are scattered in the matrix. Pelagic sedimentation took place in a deeper-water basinal environment. 

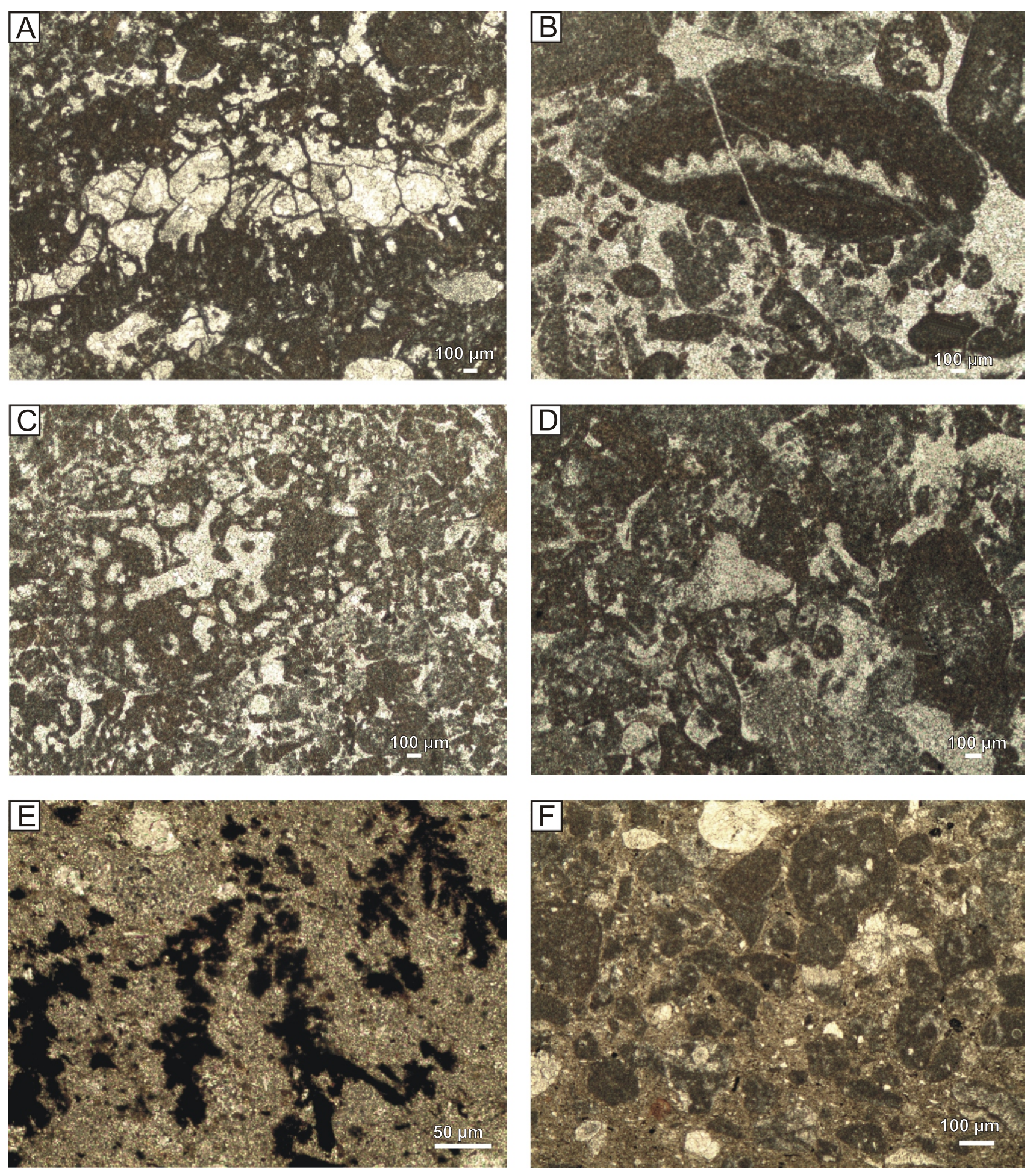

Fig. 9. Microfacies of the Dvuyakornaya Formation

A - Bacinella irregularis Radoičić identified among bioclasts in fine-grained limestone (rudstone), sample 9; B - Cyanophyceae nodule enclosing an aptychus fragment in fine-grained limestone (rudstone), sample 14; C - fragment of calcareous sponge in fine-grained limestone (grainstone), sample 3; D - planktonic crinoid Saccocoma sp. Agassiz among the bioclasts in fine-grained limestone (grainstone), sample 3; E - marly micrite matrix penetrated by shrubs of Frutexites Maslov forming dendrolite fabric, built probably of ferromanganese oxide, sample 2; F - fine-grained breccia limestone, common silty quartz, clasts of micrite limestones and bioclasts, sample 31 

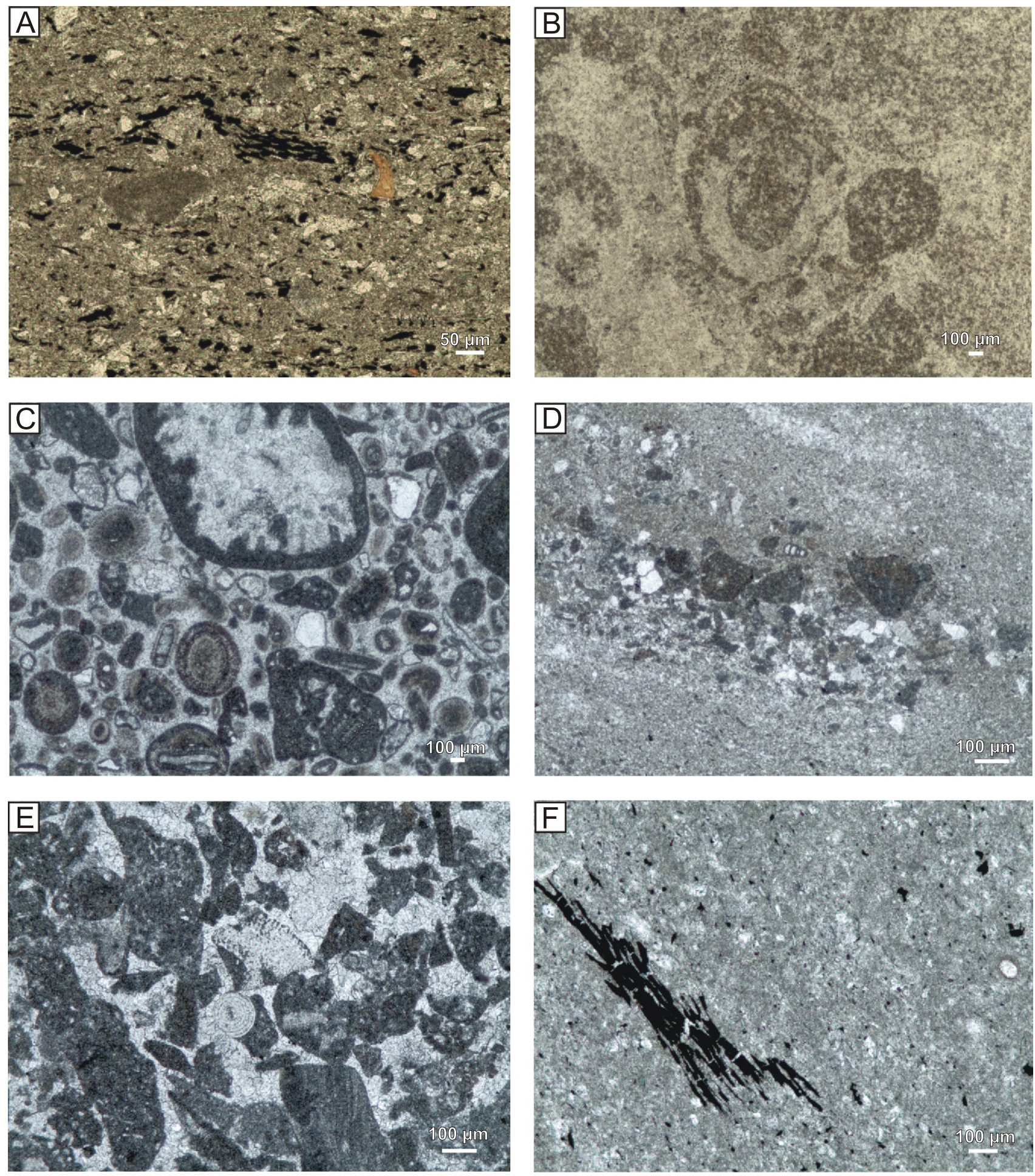

Fig. 10. Microfacies of the Dvuyakornaya Formation

A - slightly laminated marly limestone rich in silty quartz, muscovite flakes, organic matter, coalified plant fragments, rare micrite clasts and phosphatized fragments, sample 20; B - recrystallized bioclastic limestone (grainstone), sample 71; C - clast with ooids and nodule enclosing algae fragment in breccia limestone (grainstone), sample 114a; D - silty limestone with thin laminae and locally nests rich in clastic quartz, micrite clasts and rare bioclasts, sample 112; E - Cornuspira eichbergensis Kübler \& Zwingliin bioclastic limestone (grainstone), sample 97; F - Cadosina semiradiata fusca Wanner and coalified plant fragments in marly limestone, sample 103 

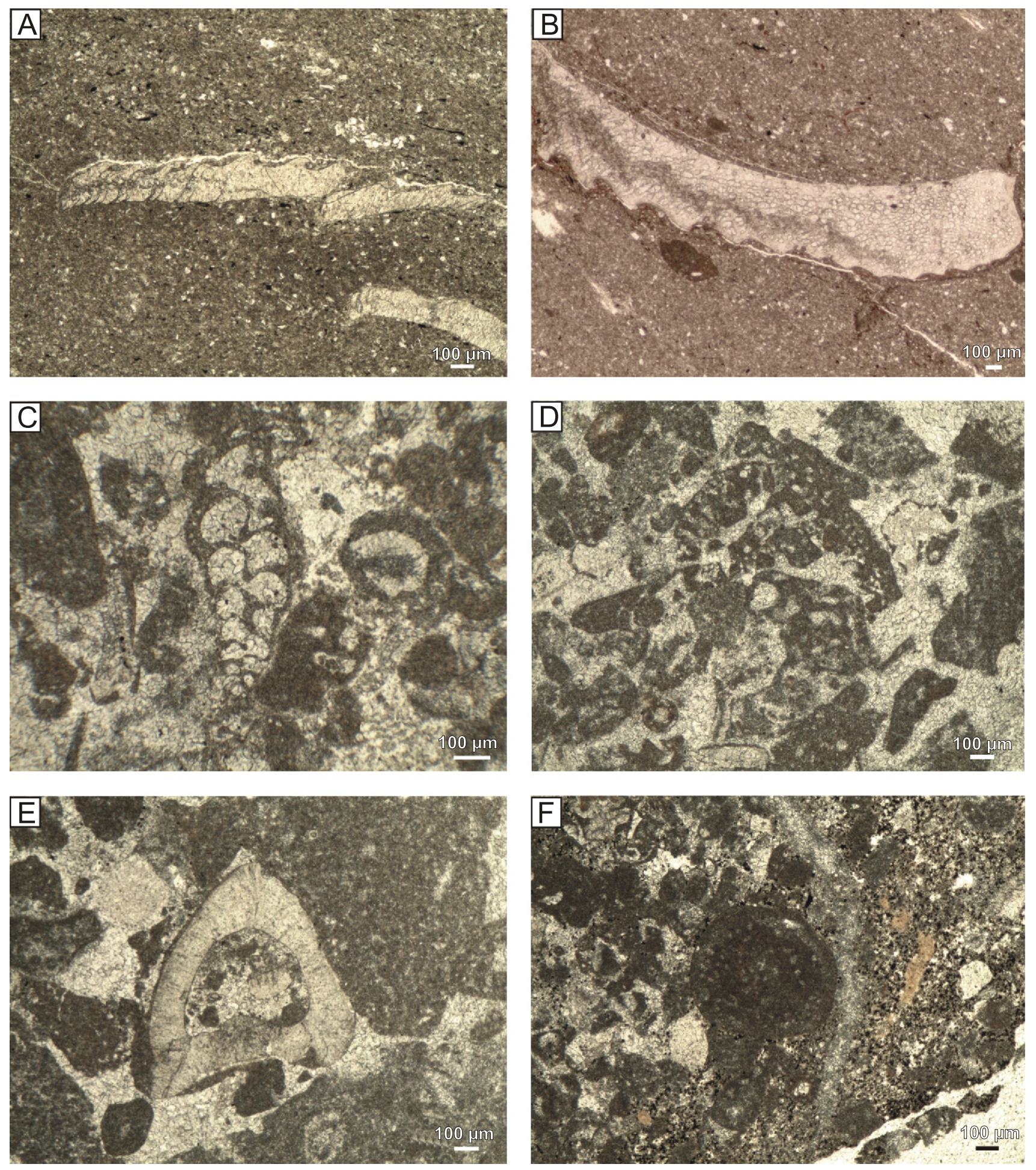

Fig. 11. Microfacies of the Dvuyakornaya Formation

A - fragment of Laevaptychus sp. in marly limestone, sample 106; B - fragments of aptychi in silty limestone, sample 102; C Praechrysalidina sp. among the bioclasts in brecciated limestone, sample 101; D - Pseudocyclammina lituus (Yokoyama) among the bioclasts in brecciated limestone, sample 95; E - worm tube of Carpathocancer triangulates (Mišík, Soták and Ziegler) in bioclastic limestone (grainstone, sample 91; F - Coprolite Favreina sp., in fine-grained brecciated limestone rich in framboidal pyrite, sample 88 

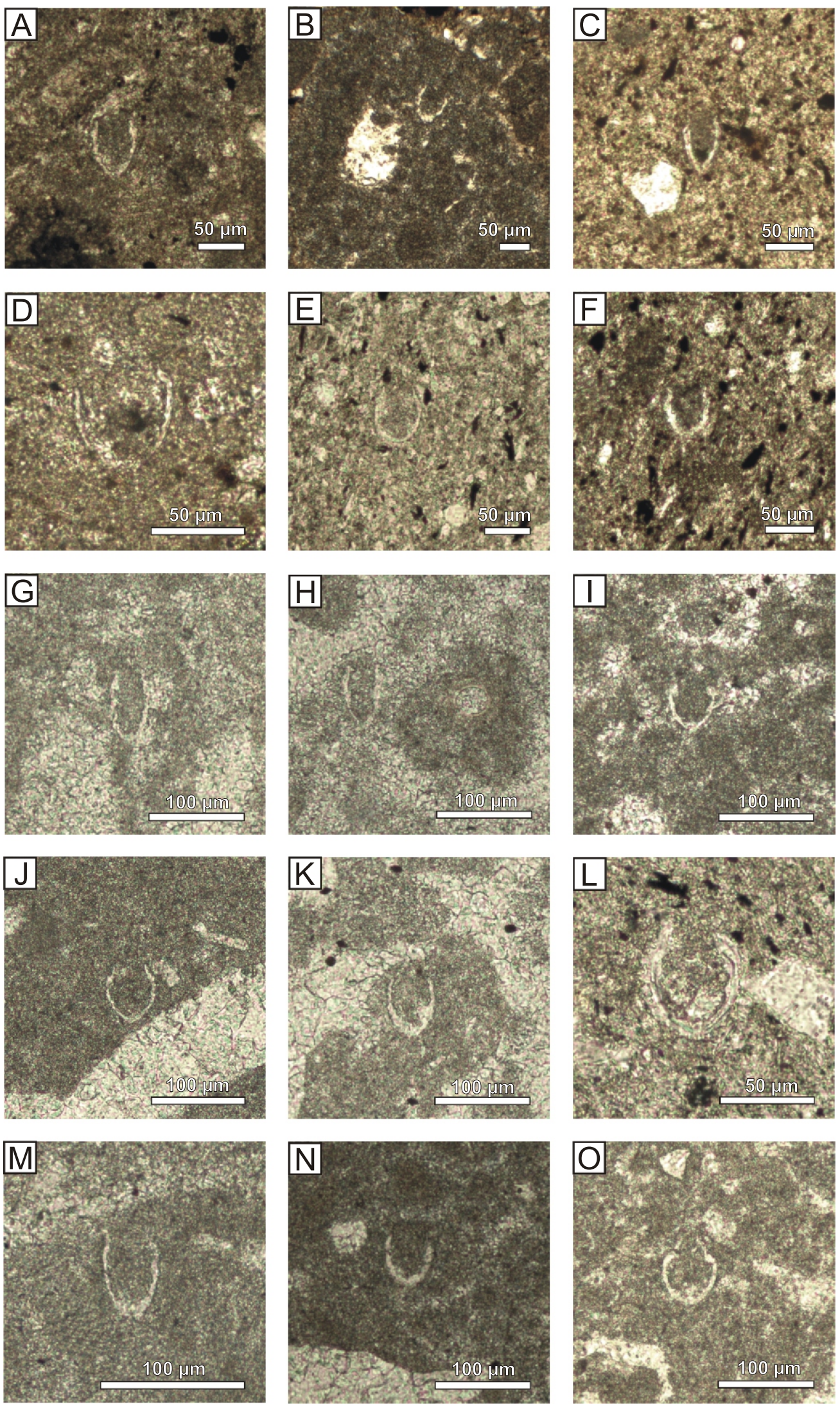

Fig. 12. Calpionellids in the Dvuyakornaya Formation

A - Crassicollaria massutiniana (Colom), sample 23; B - Crassicollaria brevis Remane enclosed in Cyanophyceae nodule, sample 23; C - Crassicollaria parvula Remane, sample 38; D, E - Calpionella alpina Lorenz, sample 20, 22; F - Crassicollaria brevis Remane, sample 20; G - Crassicollaria massutiniana (Colom), sample 60; H - Crassicollaria parvula Remane, sample 62; I - Crassicollaria brevis Remane, sample 71; J - Calpionella alpina Lorenz, sample 75; K - Tintinopsella doliphormis (Colom), sample 76; L - recrystallized Calpionella alpina Lorenz, sample 99; M - Crassicollaria massutiniana (Colom), sample 93; N - Tintinopsella remanei Borza, sample 91; $\mathbf{0}$ - Calpionella alpina Lorenz, sample 87 

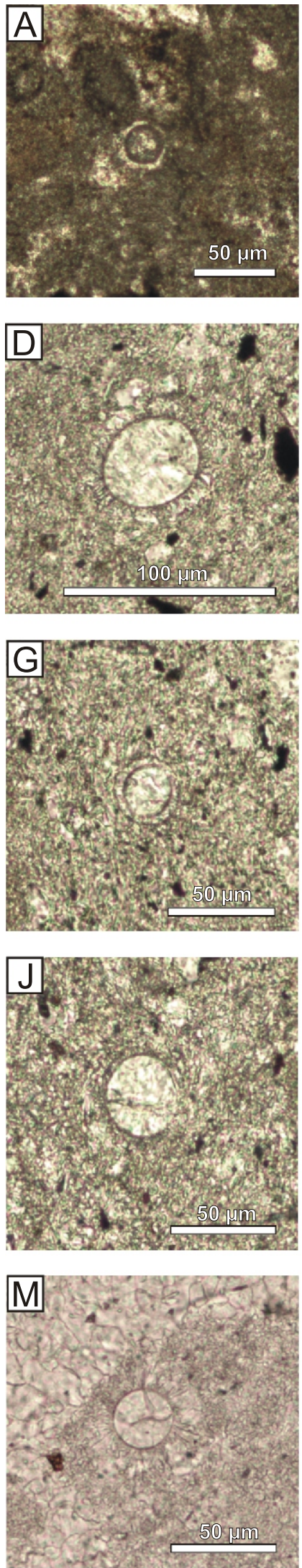
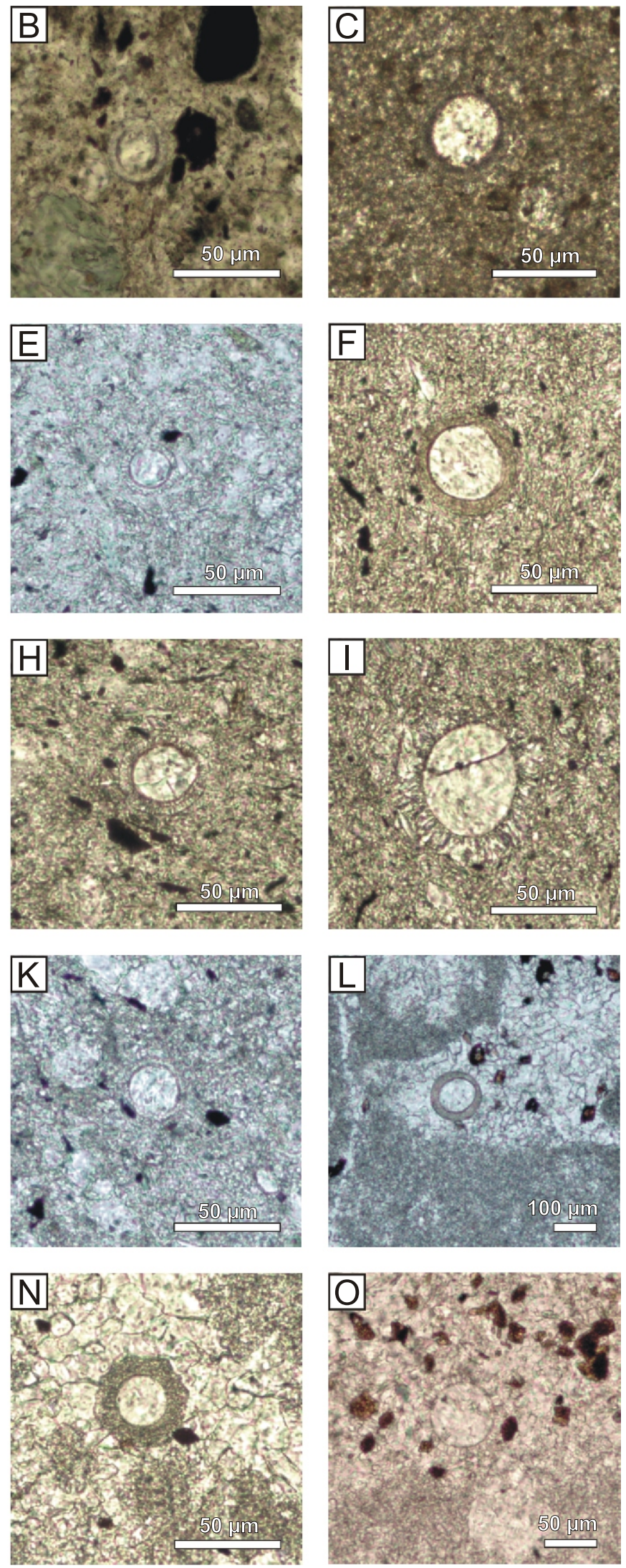

Fig. 13. Calcareous dinoflagellates in the Dvuyakornaya Formation

A - Stomiosphaerina proxima Řehánek, sample 27; B - Stomiosphaera moluccana Wanner, sample 38; C - Cadosina semiradiata semiradiata (Wanner), sample 22; D - Colomisphaera sp., sample 112; E Stomiosphaera sp., sample 112; F - Cadosina semiradiata fusca (Wanner), sample 104; G Stomiosphaera cf. moluccana Wanner, sample 104; H - Carpistomiosphaera cf. tithonica Novak, sample 104; I - Colomisphaera nagyi (Borza), sample 102; J, K - Colomisphaera fortis Řehánek, sample 98; L Cadosina semiradiata fusca (Wanner), sample 92; M - Colomisphaera carpathica (Borza), sample 89; $\mathbf{N}$ -Cadosina sp., sample 88; 0 - Colomisphaera fortis Řehánek, sample 88 


\section{STEP SECTION}

Samples $60-63,64,65,69,71$ and 76 are characterized by strong recrystallization. Fine to coarse-grained limestones (grainstones to rudstones) are built of bioclasts, nodules of Cyanophyceae and small lithoclasts (biomicrite wackestones). A few lithoclasts are dolomitized. They contain microencrusters (Crescentiella morronenis, Bacinella irregularis), and benthic foraminifera (Protopeneroplis sp., Melathrokerion sp., Nautiloculina sp., Gaudryinopsis sp.), fragments of bivalves (including oysters), ostracods, crinoids, echinoids, worm tubes, bryozoans and dasycladalean algae. Nodules of Cyanophyceae enclose small bioclasts. Rare loricas of Calpionella alpina, Crassicollaria parvula, Cr. massutiniana and Tintinnopsella carpathica (Murgeanu and Filipescu) were identified enclosed in small intraclasts.

Mixed pelagic sediments alternate with beds of eroded shallow-water allochems, regarded as gravity debris flows, deposited mainly in slope facies (Einsele, 1991; Flügel, 2004). Examples of gravity-flow deposits associated with pelagic and hemipelagic limestones have been reported in the Upper Jurassic-Lower Cretaceous sequences in many European countries (Matyszkiewicz and Słomka, 1994; Schlagintweit and Gawlick, 2007; Auer et al., 2009; Bucur et al., 2010; Guzhikov et al., 2012; Kukoč et al., 2012; Petrova et al., 2012; Wimbledon et al., 2013).

\section{LIGHTHOUSE SHACK SECTION}

Samples 86-95 consist of intraclast-bioclastic grainstones to rudstones (in mudstones). Detrital sediments (grainstones) may show distinct grading. Among the clasts are bivalves, ostracods, crinoids, echinoids, bryozoans, ooids, algae, coprolites of Favreina sp., and foraminifera species: Protopeneroplis ultragranulata (Gorbatchik), Ammobaculites sp., Praechrysalidina sp., Pseudotextulariella sp., Evolutinella sp., Coscinoconus sp., and microencruster Crescentiella morronenis (Crescenti). Also noted were tubes of Carpathocancer triangulatus (Mišík, Soták \& Ziegler) and Terebella sp., sessile foraminifera, microencrusters of Bacinella irregularis, Koskinobulina socialis Cherchi and Schroeder, which represent shallow-water environments.

Loricas of Calpionella alpina, Crassicollaria intermedia (Durand-Delga), Cr. brevis, Cr. parvula, Cr. massutiniana and Tintinnopsella carpathica were observed in clasts; one lorica of Cr. parvula was enclosed in a cyanophycean nodule. In addition, Cadosina semiradiata semiradiata, Cad. sp., Colomisphaera sublapidosa, Col. carpathica (Borza), Col. fortis Řehánek, Col. lapidosa and Stomiosphaerina proxima were observed. Samples contain rich, framboidal pyrite. Silty limestone, hard marl and calcareous clays (wackestones), locally slightly laminated, are dominant in the upper part the interval (samples 96-114). They are intercalated with layers of bioclastic grainstones witha a composition more or less similar to those already mentioned (samples 86-95). Wackestones are rich in silt-grade quartz, muscovite, pyrite (occasionally frequent glauconite) and organic matter. Locally beds show lamination and they contain scattered clasts of micritic limestones and bioclasts (some of them phosphatized). Clasts and bigger quartz grains may form thin laminae. Among bioclasts, foraminifera: Nautiloculina bronnimanni Arnaud-Vanneau and Peybernés, Coscinoconus alpines Leupold (in Leupold and Bigler, 1936), Pseudocyclammina lituus (Yokoyama), Evolutinella sp., Protopeneroplis sp., Neotrocholina sp., Patellovalvulina sp., Pseudotextulariella sp., ostracods, bivalves, aptychi fragments, also cysts of Cadosina semiradiata fusca (Wanner), Col. fortis, Col. cf. fortis Řehánek, Col. lapidosa, Col. nagyi (Borza), Carpistomiosphaera tithonica Nowak, Parastomiosphaera malmica (Borza), Stomiosphaera moluccana Borza and St. sp. were identified. There were no calpionellids identified in the wackestone matrix. Two loricae of Calpionella alpina and one of Crassicollaria parvula were documented enclosed in micrite clasts in wackestone samples 98-99. Rich assemblages of Cadosina semiradiata fusca are observed in the early Tithonian Semiradiata Zone (Lakova et al., 1999; Reháková, 2000a), but the composition of the cyst association mentioned above indicates erosion of older sediments and their transport into Late Tithonian to Early Berriasian palaeoenvironments.

\section{MICROFACIES AND MICROFOSSILS OF THE MAYAK FORMATION}

Mayak Formation samples (marly limestones, clayey limestones, fine-grained to brecciated limestones) were studied from the lli Burnu lighthouse cliff (Fig. 3, samples 115-164), the "Middle Cliff" (Fig. 3, samples 165-189), and the Boathouse Cliff (Fig. 3, samples 198-223). Microfacies, calpionellids and calcareous dinoflagellates of the formation are shown in Figures 14-16.

The study of thin sections from the profiles mentioned above shows several types of microfacies:

1. Marly micrites/biomicrite in some layers may be laminated and bioturbated. Besides rich nannoplankton, mudstones contain frequent calcified radiolarians, sponge spicules, ostracods, globochaetes, foraminifera (Lenticulina sp., Spirillina sp., Nodosaria sp.), crinoids, bivalves, filaments (=fragments of very small bivalves), and aptychi. The matrix is locally penetrated by abundant growths of Frutexites Maslov. Some small bioclasts are recrystallized, locally also phosphatized, and some are silicified. The matrix is rich in pyrite (also framboidal), and pyrite creates nests and impregnates bioclasts. Frequent, small, coalified plant fragments, silt-grade quartz grains, muscovite and rare glauconite are scattered in the muddy matrix.

2. Marly biomicrite limestones (wackestones) contain, besides small fragments of echinoderms, ostracods, bivalves, and few microfossils resembling planktonic foraminifera, infrequent calpionellids and calcareous dinoflagellates. Crassicollaria parvula Remane, Calpionella alpina Lorenz, Calp. minuta Houša, Calp. elliptica Cadisch, Tintinnopsella carpathica (Murgeanu and Filipescu), Tint. doliphormis (Colom), Lorenziella hungarica Knauer, Lorenziella cf. plicata Remane, Remaniella catalanoi Pop, Rem. colomi Pop were identified. Some of calpionellids have dark micrite borders, because of the higher content of organic matter formed by bio-coagulation. The cyst associations contain Colomisphaera aff. fortis Řehánek, Col. tenuis (Nagy), Stomiosphaera aff. wanneri Borza, St. sp., Col. nagyi, Col. carpathica, Col. cieszynica and Carpistomiosphaera sp., Cadosina semiradiata fusca, Cad. semiradiata semiradiata accompanied by the long-ranging species Colomisphaera lapidosa. Calpionellid species are typical of the Elliptica Subzone. Most of dinoflagellate cysts observed come from eroded early Tithonian sediments (Lakova et al., 1999; Reháková, 2000a).

Sample 147 yielded some deep-water agglutinated taxa: Rhabdammina sp., Reophax sp., Glomospira 

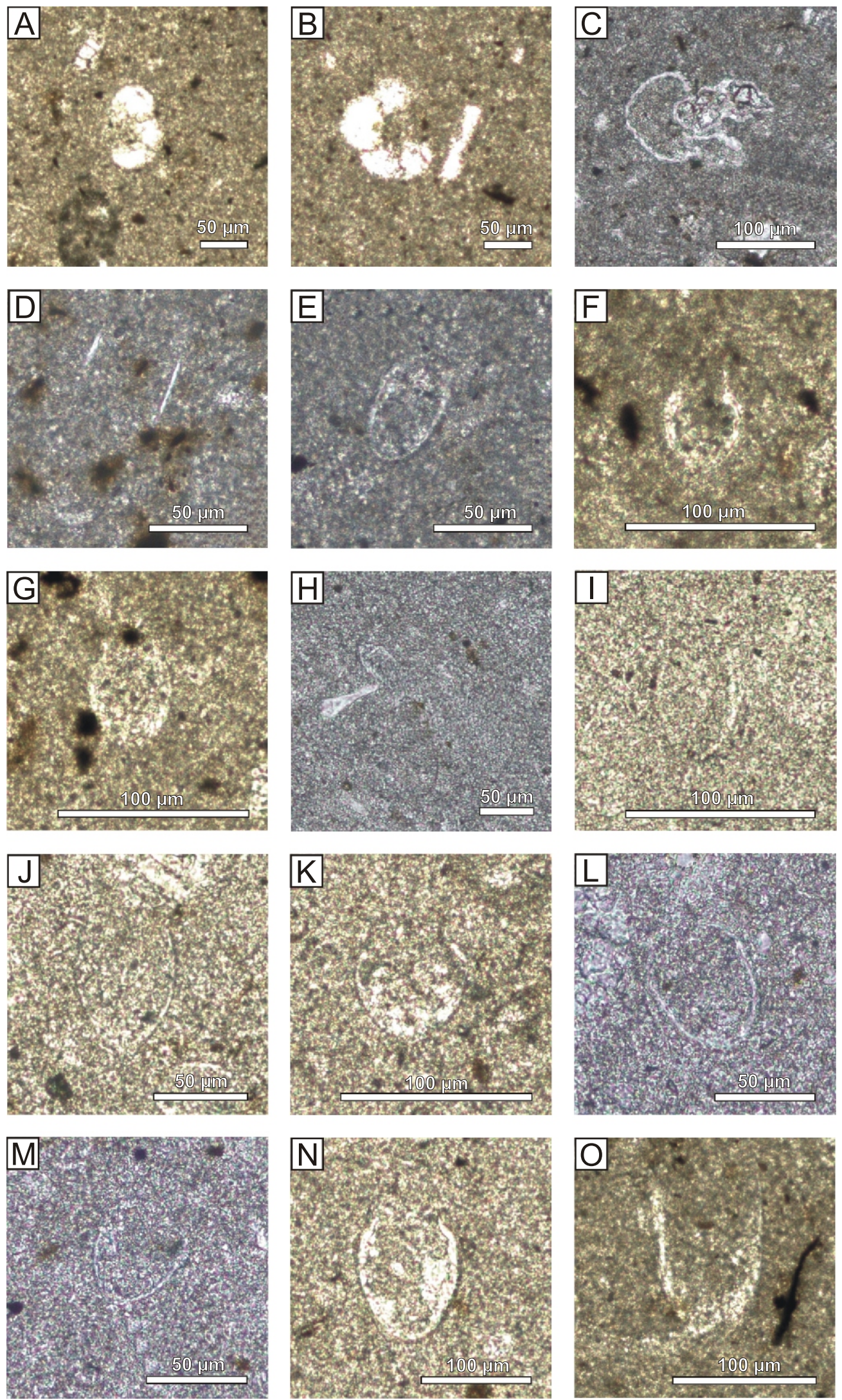

Fig. 14. Calpionellids in the Mayak Formation

A-C - tests of probable planktonic foraminifera, samples $160,123,146$; D - probable tintinnopsellid lorica, sample 127; E - Calpionella elliptica Cadisch, sample 127; F - Calpionella minuta Houša, sample 134; G - Lorenziella plicata Remane, sample 126; H - probable calpionellid lorica, sample 136; I, J Tintinnopsella carpathica (Murgeanu and Filipescu), samples 136, 137; K - Lorenziella hungarica Knauer and Nagy, sample 137; L, M - probable remaniellid loricas, samples 137, 138; N - Lorenziella plicata Remane, sample 138; O - probable tintinnopsellid lorica, sample 146 

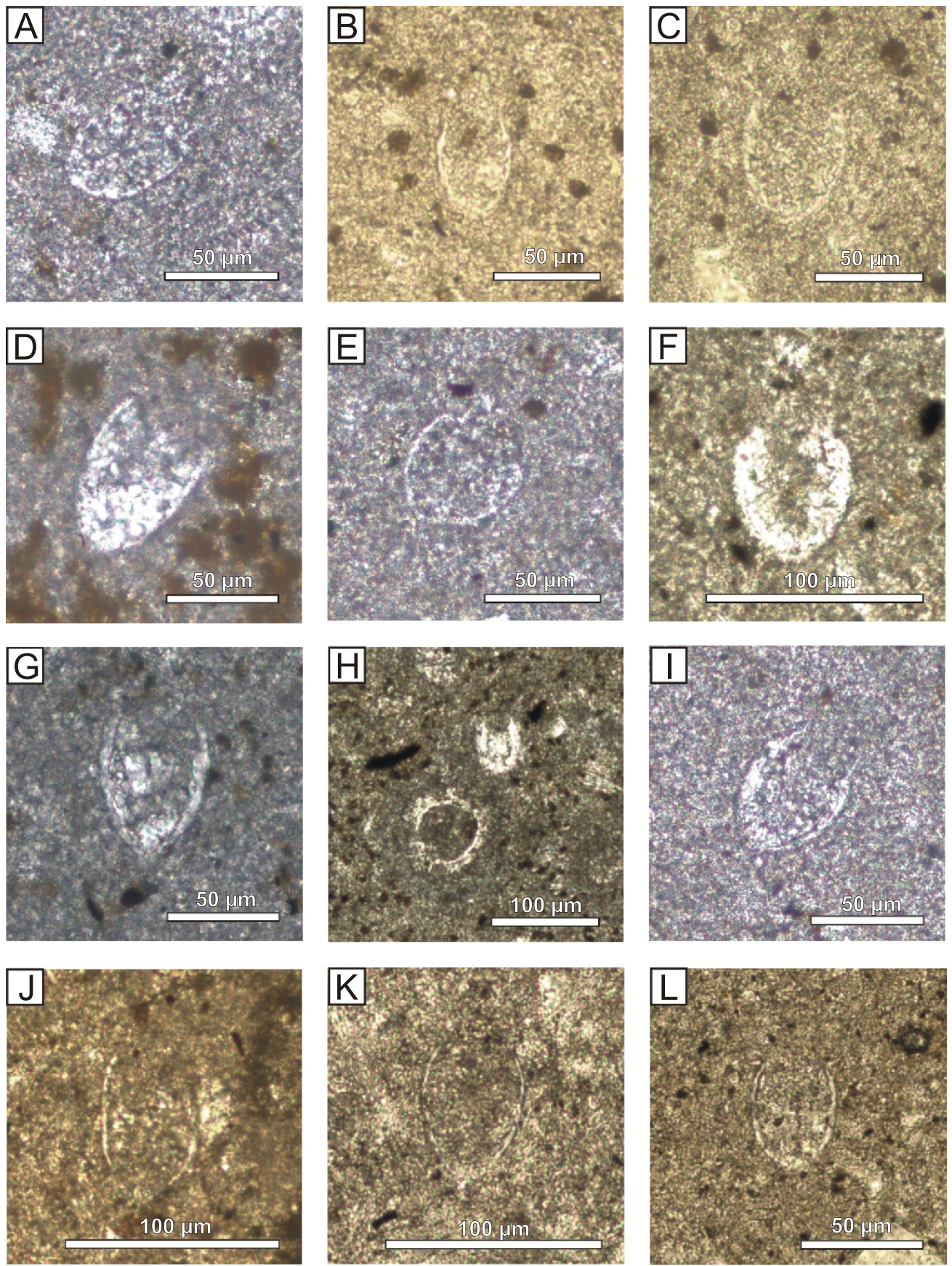

Fig. 15. Calpionellids in the Mayak Formation

A - Calpionella elliptica (Cadisch), sample 150; B - Crassicollaria massutiniana (Colom), sample 164; C Tintinnopsella carpathica (Murgeanu and Filipescu), sample 164; D - Remaniella colomi Pop., sample 150; E, F - Lorenziella hungarica Knauer and Nagy, samples 146, 150; G -Tintinopsella doliphormis (Colom), sample 145; H - recrystalized calpionellid loricas in micrite clast, sample 143; I - Lorenziella plicata Remane, sample 138; J - Remaniella colomi Pop, 1996, sample 208; K - Tintinnopsella carpathica (Murgeanu and Filipescu), sample 208, L - Remaniella colomi Pop, 1996, sample 223 

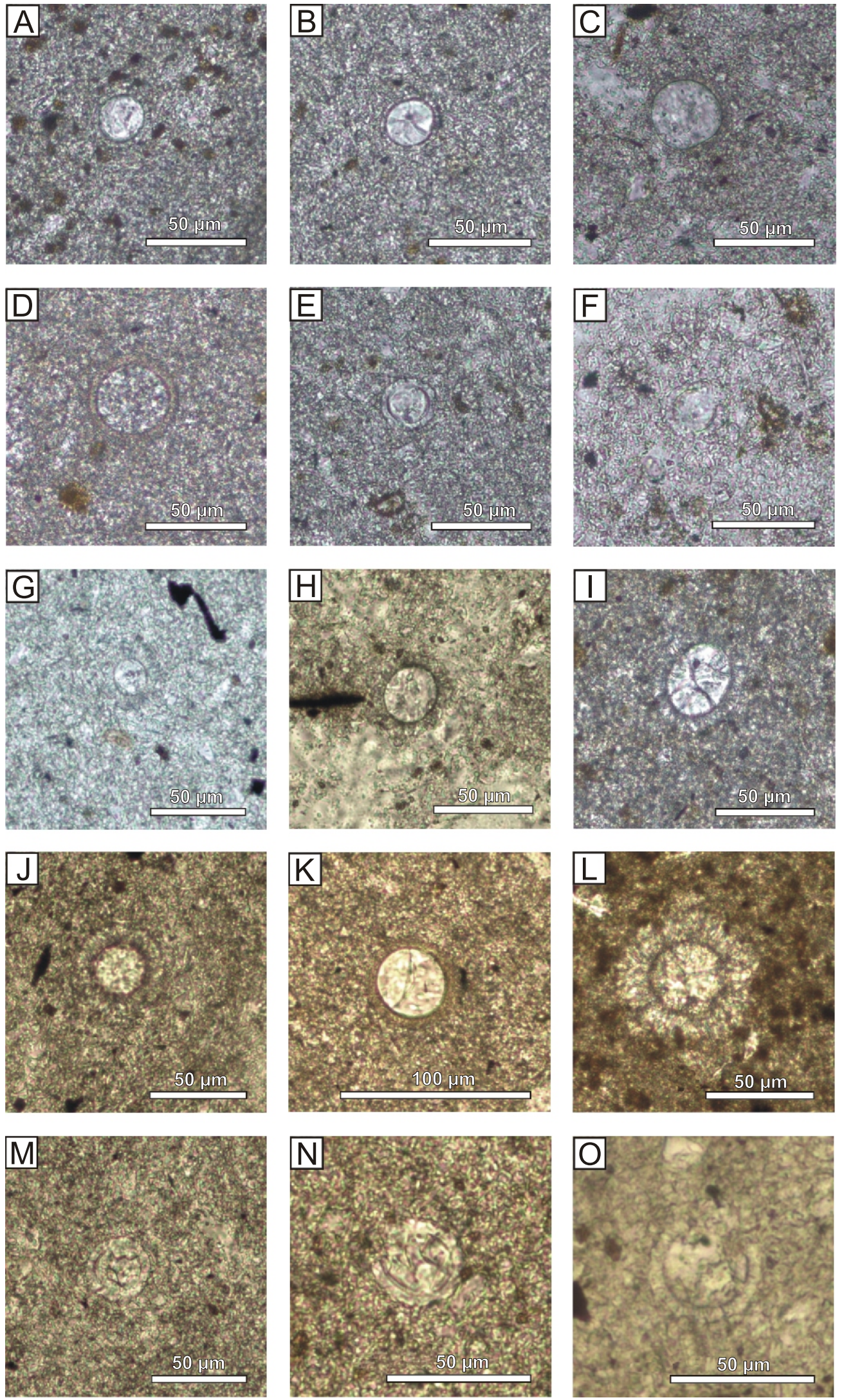

Fig. 16. Calcareous dinoflagellates in the Mayak Formation

A, B - Colomisphaera fortis Řehánek, samples 143, 145; C - Carpistomiosphaera sp., sample 120; D Cadosina semiradiata fusca (Wanner), sample 164; E, F - Stomiosphaera wanneri Borza, sample 147; G - Colomisphaera cieszynica Novak, sample 148; H, I - Colomisphaera sp., sample 120, 143; J Colomisphaera cf. heliosphaera (Vogler), sample 186; K - Cadosina semiradiata fusca (Wanner), sample 180; L - Colomisphaera cieszynica Novak, sample 220; M, N - Stomiosphaera sp., sample 180; O Colomisphaera lapidosa (Vogler), sample 221 
gordialis (Jones \& Parker), Ammogloborotalia abrupta (Geroch), Verneuilinoides cf. neocomiensis (Mjatliuk), Haplophragmoides sp., and Kutsevella implana (Crespin). Holbourn and Kaminski (1997) recorded Ammogloborotalia abrupta in the Tithonian and Valanginian and Kutsevella implana (Crespin) in Tithonian to Hauterivian sediments.

Among the calcareous benthic foraminifera, Spirillina sp., Laevidentalina nana (Reuss), Laevidentalina oligostegia (Reuss), Laev. spp., Lenticulina muensteri (Roemer), Lent. sp., Saracenaria sp., Astacolus sp., Lingulina cf. loryi (Berthelin), ?Epistomina sp., ?Paalzowella spp. and ?Reinholdella sp. were observed. Spirilina, Lingulina and some other foraminifera with calcareous tests show good glassy preservation. The rest of the larger tests are rather badly preserved (possibly redeposited, mainly the larger calcareous tests of Lenticulina, ?Epistomina sp., ?Paalzowella spp., and ?Reinholdella sp.). Infaunal morphogroups are rather common, suggesting a well-oxygenated sedimentary environment. Among accessory fossils, fragments of ostracods (smooth and ornamented), juvenile gastropods, sponge spicules (monaxons) and fish teeth were observed.

Mudstones to wackestones locally contain thin laminae rich in silt-grade quartz grains, muscovite, bioclasts and clasts of biopelmicrite limestones and rare ooids derived from shallower proximal environments. Bioclasts and clasts of biomicrite/biopelmicrite limestones occur scattered in the matrix. Some of the smallest micrite clasts are difficult to observe and their size approaches that of peloids. Clasts contain foraminifers (Patellina sp. and Involutina sp.), echinoids, ostracods, sponge spicules, bivalves and crinoids. Loricas of Calpionella alpina, Tintinnopsella carpathica and Remaniella sp. were also observed in clasts. Clasts in laminae may show distinct grading.

3. Hard marls and calcareous clays (samples 125, 129, $135,140-142,148)$ contain very rare ostracods and hyaline foraminiferan fragments (some of them silicified) and cysts of Colomisphaera lapidosa, Col. fortis, Col. sp., Cadosina semiradiata fusca and Stomiosphaera $\mathrm{sp}$. They contain rich, dispersed organic matter and pyrite, abundant plant fragments, common silt-grade quartz grains, muscovite and phosphatized bioclasts. No calpionellid was observed in these sediments.

4. Fine-grained to brecciated limestones (grainstones) with bioclasts and clasts of biomicrite limestones in which fragments of bivalves, miliolid foraminifers, globochaetes, ostracods, crinoids and echinoids spines were observed. Rare calpionellid loricas are enclosed in limestone clasts and nodules of Cyanophyceae. Micro-encrusters Koskinobullina socialis Cherchi and Schroeder, Tubiphytes obscurus Maslov and Bacinella irregularis Radoicic, and fragments of red and dasycladalean algae were identified. Both the matrix and bioclasts are locally recrystallized.

Grainstones contain very rich associations of calcareous and agglutinated foraminiferan species. In samples 115 and 118-124, relatively few foraminifera were found and mainly calcareous dinoflagellate cysts. The foraminifera species are: Patellina turriculata Dieni \& Massari, Epistomina cf. caracolla (Roemer), Protopeneroplis sp., Uvigerinammina sp., Astacolus cf. calli- opsis (Reuss), Spirillina minima Schacko, Arenobulimina sp., Reophax sp., Ophthalmidium sp., Lenticulina sp., and the enigmatic Jurassic-Cretaceous microfossil Crescentiella morronensis (Crescenti).

\section{CALPIONELLID STRATIGRAPHY}

An early investigation of sections near to Theodosia by Sazonova and Sazonov (1984) recorded Late Tithonian calpionellids with rich Crassicollaria intermedia and Crassicollaria sp. in limestones with an ammonite fauna of Malbosiceras chaperi and Berriasella jacobi. A Late Berriasian calpionellid association (Calpionellopsis oblonga, Calpionellopsis simplex, Tintinnopsella ex. gr. carpathica and T. longa) they identified in a higher limestone interval together with the ammonites Fauriella boissieri and Riasanites (Tauricoceras) spp. These authors stated that an Early Berriasian interval (represented by Calpionella alpina, C. elliptica and Tintinnopsella carpathica s. str.) was not identified near Theodosia. Unfortunately, calpionellids listed by Sazonova and Sazonov (1984) were not figured in their paper.

After our team started work on the biostratigraphy at Theodosia, calpionellids were also studied by Shchennikova and Arkad'ev (2009), Platonov and Arkad'ev (2011). Platonov (in Arkad'ev et al., 2012), in preliminary results, identified Late Berriasian to Early Valanginian calpionellid associations composed of Calpionellites sp., Remaniella sp., Remaniella cf. cadischiana, Calpionellopsis ex. gr. simplex, and Tintinnopsella colomi. Calpionella elliptica and T. longa (taxa found in the uppermost Lower Berriasian) were identified (Platonov in Arkad'ev et al., 2012). Completely different results from the same section were later published (Platonov et al., 2013), and the authors omitted the above-mentioned calpionellid association and replaced it with associations typical for the standard Chitinoidella, Crassicollaria and Calpionella zones, known from coeval sequences in the western Tethyan area.

Calpionellids in the Dvuyakornaya Formation are predominantly Late Tithonian species and they are mostly enclosed in small micrite lithoclasts and rarely in Cyanophyceae nodules. We are not able to define a concrete biozonal scheme, such as those defined in coeval successions further west in Tethys (Remane et al., 1986; Pop, 1997; Reháková and Michalík, 1997; Lakova et al., 1999; Andreini et al., 2007; Lakova and Petrova, 2013). Calcareous dinoflagellate cysts are well-preserved and a succession of cyst events (sensu Borza, 1984; Lakova et al., 1999, 2007; Reháková, 2000a; Ivanova, 2000) have been recognised.

In the Mayak Formation, calpionellids, besides their presence in clasts, are also documented in matrix, though they are rare and have badly preserved collars on the lorica. In the associations observed, species belonging to the Alpina, Ferasini and Elliptica subzones (Calpionella Zone) can be identified. It was not possible to define strictly the onset of these subzones, nor the presence of calpionellid species of the younger (Late Berriasian to Early Valanginian) calpionellid zones. Most of the calcareous dinoflagellates cysts investigated in the Mayak Formation indicate the erosion of older (Early Tithonian) sediments.

Calcareous dinoflagellates and calpionellids are accompanied by a few planktonic foraminifera. Such types of assemblage have been described in many sequences in the Tethyan area (Borza, 1984; Rehehánek, 1985; Reháková, 2000b) and also from the Polish Trough (Olszewska, 2010). 


\section{CALCAREOUS DINOFLAGELLATE CYSTS}

In the studied intervals we have identified calcareous cysts typical for the Early and Late Tithonian and the Berriasian: Cadosina semiradiata semiradiata, Cad. semiradiata fusca Wanner, Colomisphaera lapidosa, Col. tenuis, Col. fortis, Carpistomiosphaera tithonica, Stomiosphaerina proxima, St. moluccana, and St. wanneri. In the lowermost part of the section, the species Colomisphaera fortis, Carpistomiosphaera tithonica, Col. lapidosa, Col. tenuis and Stomiosphaera moluccana were determined. In samples 27 and 120 the stratigraphically important species Stomiosphaerina proxima Rěhánek (S. proxima Zone) has been identified. According to Rehánek (1992) the first occurrence of this taxon characterizes the $\mathrm{J} / \mathrm{K}$ boundary.

In Bulgaria, this species coincides with the first appearance of the species Calpionella grandalpina and Microstaurus chiastius (Lakova et al., 1999). Stomiosphaerina proxima is a relatively long-ranging species established from the upper part of the Upper Tithonian and the whole Berriasian, except its very top (Lakova et al., 1999). Reháková (2000a) confirmed these results. Thus, the zonation based on calcareous cysts is considered to start with the onset of the S. proxima Zone in the Late Tithonian in Europe west of Ukraine.

The presence of some species here in Lower Berriasian beds indicates that they are resedimented: Stomiosphaera moluccana, Carpistomiosphaera tithonica (only Lower Tithonian species); Colomisphaera tenuis, Col. fortis (Upper Tithonian species). On the contrary, Stomiosphaera wanneri is normally found higher in the Berriasian (e.g., W Carpathian or W Balkan Calpionellopsis oblonga Subzone; Reháková, 2000a Grabowski et al., 2016) suggesting that its first appearance must be revised. Cadosina semiradiata semiradiata, Cad. semiradiata fusca and Colomisphaera lapidosa are long-ranging species, but the first two occur as globally visible ecoevents, blooms: the first during the Early Tithonian Semiradiata Zone (Reháková, 2000b), i.e. preceding the Chitinoidella Zone, and the second widespread in the Elliptica to Oblonga subzones.

\section{BENTHIC FORAMINIFERA}

Detailed observations on foraminiferans are based on an examination of materials from the lower Mayak Formation at Ili Burnu. Samples from the formation contain the following foraminiferan genera and species: Anchispirocyclina lusitanica (Egger), Nautiloculina bronnimanni Arnaud-Vanneau \& Peybernés, Melathrokerion valserinensis Brönnimann \& Conrad, Protopeneroplis ultragranulata (Gorbachik), Patellina turriculata Dieni \& Massari, Meandrospira favrei (Charollais, Brönnimann \& Zaninetti), Pseudocyclammina lituus (Yokoyama), Coscinophragma cribrosum (Reuss), Cyclogyra cf. cretacea (Reuss), Conorboides hofkeri (Bartenstein \& Brand), Epistomina cf. caracolla (Roemer), Glomospiragordialis (Jones \& Parker), Dentalina-Marginulina group, Epistomina sp., Reophax sp., Lenticulina sp., Trochammina sp., Ophthalmidium sp., Nubecularia sp., Gaudryinella sp., as well as an association of representatives of the genera Coscinoconus and Neotrocholina. Benthic foraminifera are shown in Figures 17-21.

In samples 115 and 118-124 relatively few foraminifera were found and mainly calcareous dinoflagellate cysts. The foraminifera are: Epistomina sp. (probably E. uhligi Mjatliuk),
Protopeneroplis sp., Uvigerinammina sp., Vaginulinopsis sp., Arenobulimia sp., Reophax sp., Ophthalmidium sp., Lenticulina $\mathrm{sp}$., sections attributed to the Dentalina-Marginulina group and also the enigmatic Jurassic-Cretaceous microfossil Crescentiella morronensis (Crescenti).

Foraminiferan genera and species in samples 126-128 are: Cyclogyra cf. cretacea (Reuss), Coscinoconus sp., Valvulinas sp., and sections attributed to the Dentalina-Marginulina group.

In samples 130-134, the following were identified: Meandrospira favrei, Patellina turriculata Dieni \& Massari, Verneuilinoides neocomiensis (Mjatliuk), Cyclogyra cf. Cretacea (Reuss), Nubecularia depressa Chapman, Epistomina sp., Conorboides sp., Gaudryinopsis sp., Ophthalmidium sp., and some recrystallised sections belonging to Coscinoconus alpinus Leupold in Leupold and Bigler, C. elongatus Leupold in Leupold and Bigler, C. cherchiae (Arnaud-Vanneau, Boisseau \& Darsac) and Neotrocholina valdensis Reichel.

Recorded stratigraphic ranges are as follows: Meandrospira favrei - Valanginian (Schlagintweit and Ebli, 1999; Bucur et al., 2004; Ivanova et al., 2008; Ivanova and Kołodziej, 2010) to Lower Aptian (Neagu, 1970); Patellina turriculata - Upper Berriasian (Bucur, 1988) to Barremian (Altiner, 1991); Verneuilinoides neocomiensis - uppermost Tithonian (Kuznetsova, 1974) to Aptian (Riegraf and Luterbacher, 1989; Jones and Wonders, 1992); Redmondoides lugeoni Septfontaine - ?Lias or Bajocian (Septfontaine, 1977) to Valanginian (Ivanova and Kołodziej, 2010); Neotrocholina valdensis - Late Berriasian to Valanginian. The Coscinoconus assemblage is typical of the Berriasian to Valanginian (Arnaud Vanneau et al., 1988; Neagu, 1994, 1995; Bucur et al., 1995; Mancinelli and Coccia, 1999).

In samples 136-139, calcareous dinocysts were predominantly found and only one section of a foraminiferan Cyclogyra cf. cretacea (Reuss) (sample 139). The same species was found in sample 143, together with Quinqueloculina egmontensis Lloyd and Trochammina sp. Quinqueloculina egmontensis ranges from the Kimmeridgian (Dulub and Terestschuk, 1964; Gutowski et al., 2005) to the Albian (Neagu, 1984, 1985, 1986). Samples 149-154 contain Haplophragmium aeguale (Roemer), Cyclogyra cf. cretacea (Reuss), and Frondicularia sp.

The uppermost samples are of greatest stratigraphic interest. Samples 155-159 show saturation of calcareous dinocysts, but in sample 157 also a rich association of benthic foraminifera: Anchispirocyclina lusitanica, Protopeneroplis ultragranulata (Gorbatchik), Nautiloculina bronnimanni, Melathrokerion valserinensis Broennimann \& Conrad, Pseudocyclammina lituus, Everticyclammina virguliana Maync, Coscinophragma cribrosum (Reuss), Mohlerina basiliensis (Mohler), Glomospira gordialis (Jones \& Parker), Quinqueloculina egmontensis, Lenticulina sp., Globulina sp. and a rich Coscinoconus-Neotrocholina assemblage.

Protopeneroplis ultragranulata (Gorbachik, 1971) was firstly described and illustrated as Hoeglundina (?) ultragranulata from the Upper Tithonian-Berriasian of Crimea. The species was described in the Russian literature, but was overlooked for a long time. Anchispirocyclina lusitanica (Egger) was formerly considered the best marker of the Tithonian, for its range was thought to be restricted to this Jurassic stage. However, finds in M18 of the Bias do Norte section (Portugal) documented its occurrence in strata with an apparently earliest Berriasian age (Granier and Bucur, 2011). 

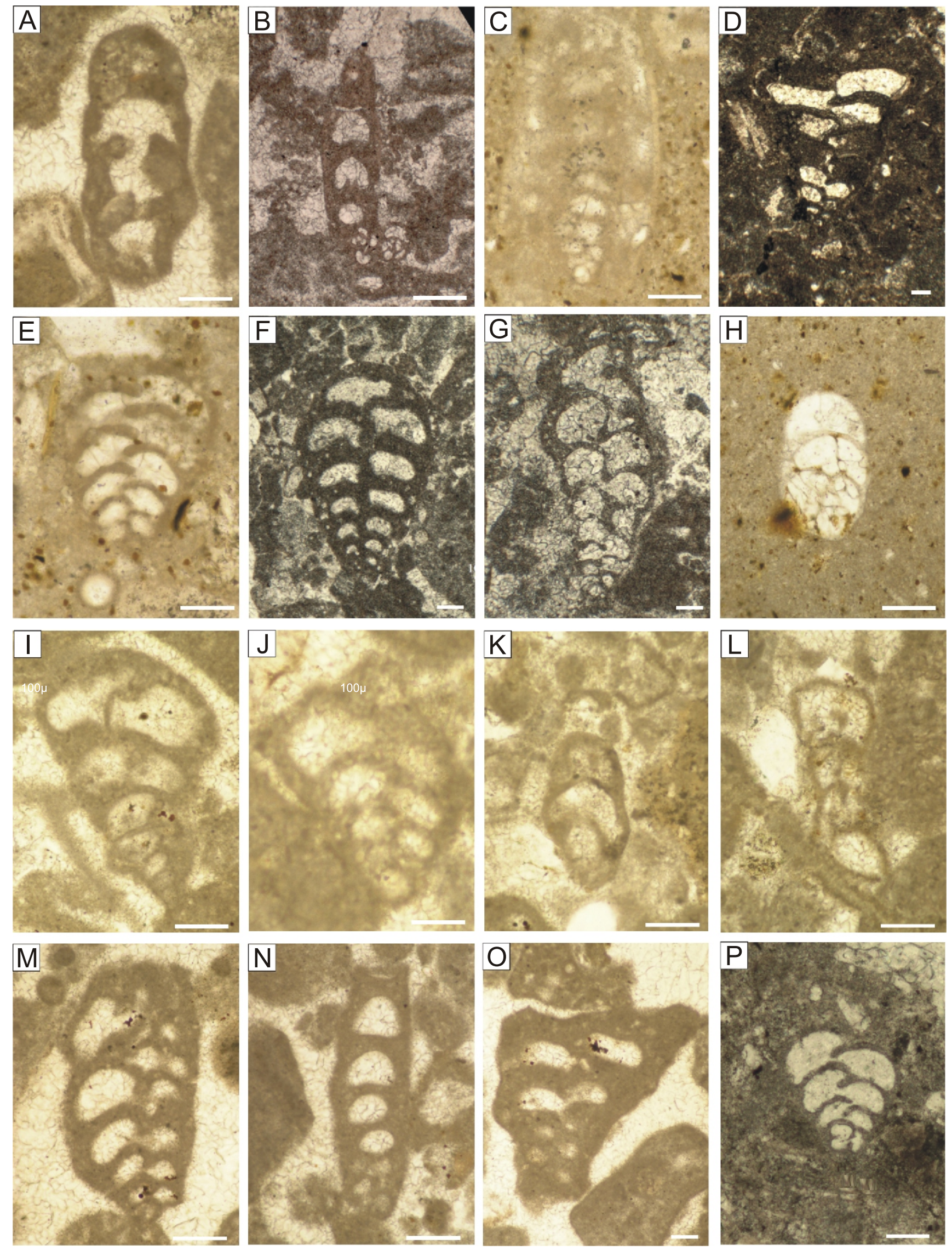

Fig. 17. Benthic foraminifera

A - Reophax sp., sample 163; B - Ammobaculites sp., sample 88; C - Haghimashella arcuate (Haeusler), sample 132; D Protomarssonella sp., sample 23; E - Redmondoides lugeoni (Septfontaine), sample 132; F - Siphovalvulina? sp., sample 163; G -

Praechrysalidina sp., sample 101; H - Uvigerinammina sp., sample 123; I-L - Verneuilinoides cf. neocomiensis (Mjatliuk), sample 157; M-0 - Protomarssonella aff. hechti (Dieni \& Massari), sample 163; P - Gaudryinopsis sp., sample 23; scale bar length is 100 microns 

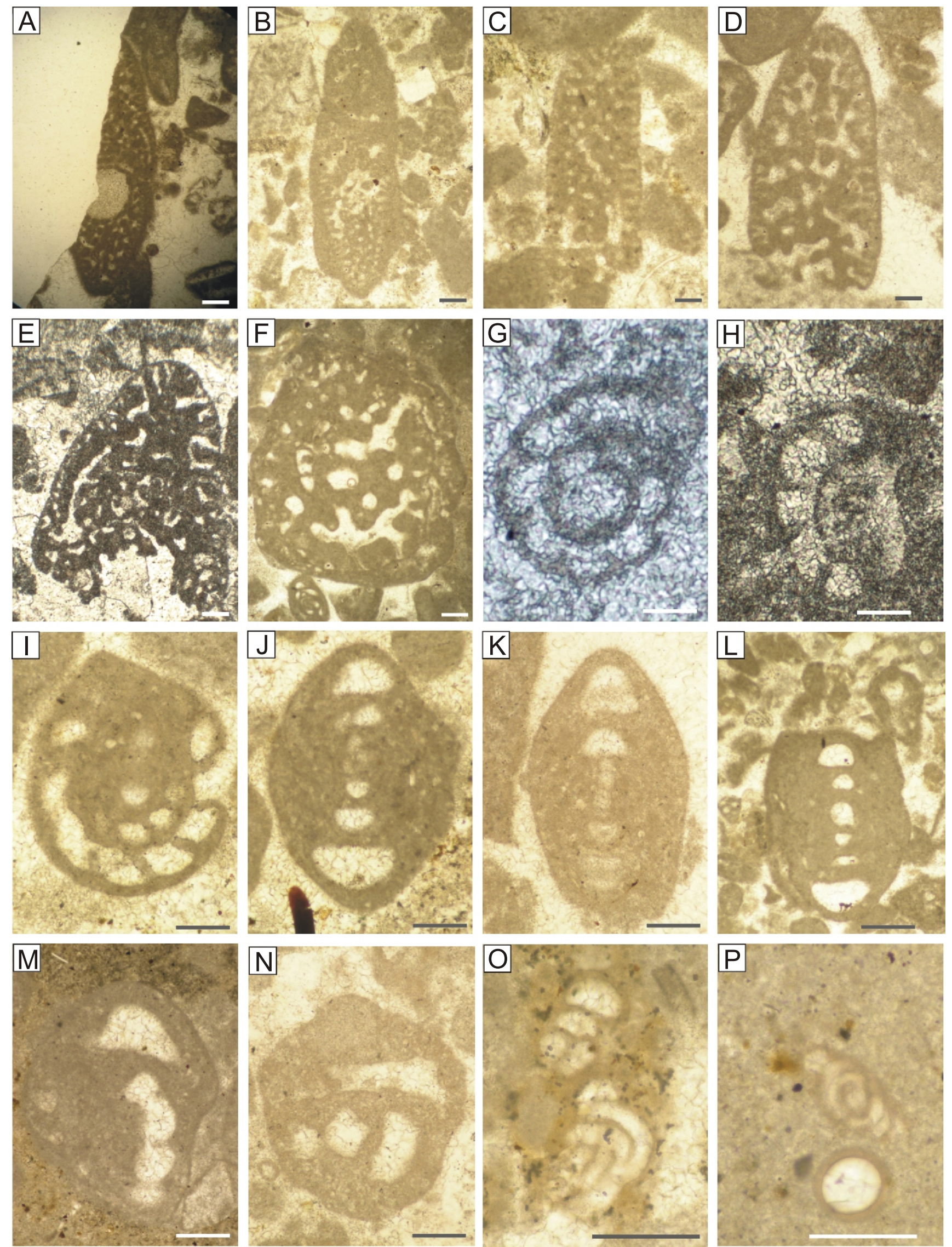

Fig. 18. Benthic foraminifera

A-D - Anchispirocyclina lusitanica (Egger), sample 162, 163, 164, 157; E - Pseudotextulariella sp., sample 86; F - Coscinophragma cribrosum (Reuss), sample 157; G - Evolutinella sp., sample 93; H-L - Nautiloculina bronnimanni Arnaud-Vanneau \& Peybernés, sample 57; M, N - Melathrokerion valserinensis Brönnimann \& Conrad, sample 163; O - Glomospira charoides (Jones and Parker), sample 57; P Glomospirella sp., sample 152; scale bar length is 100 microns 

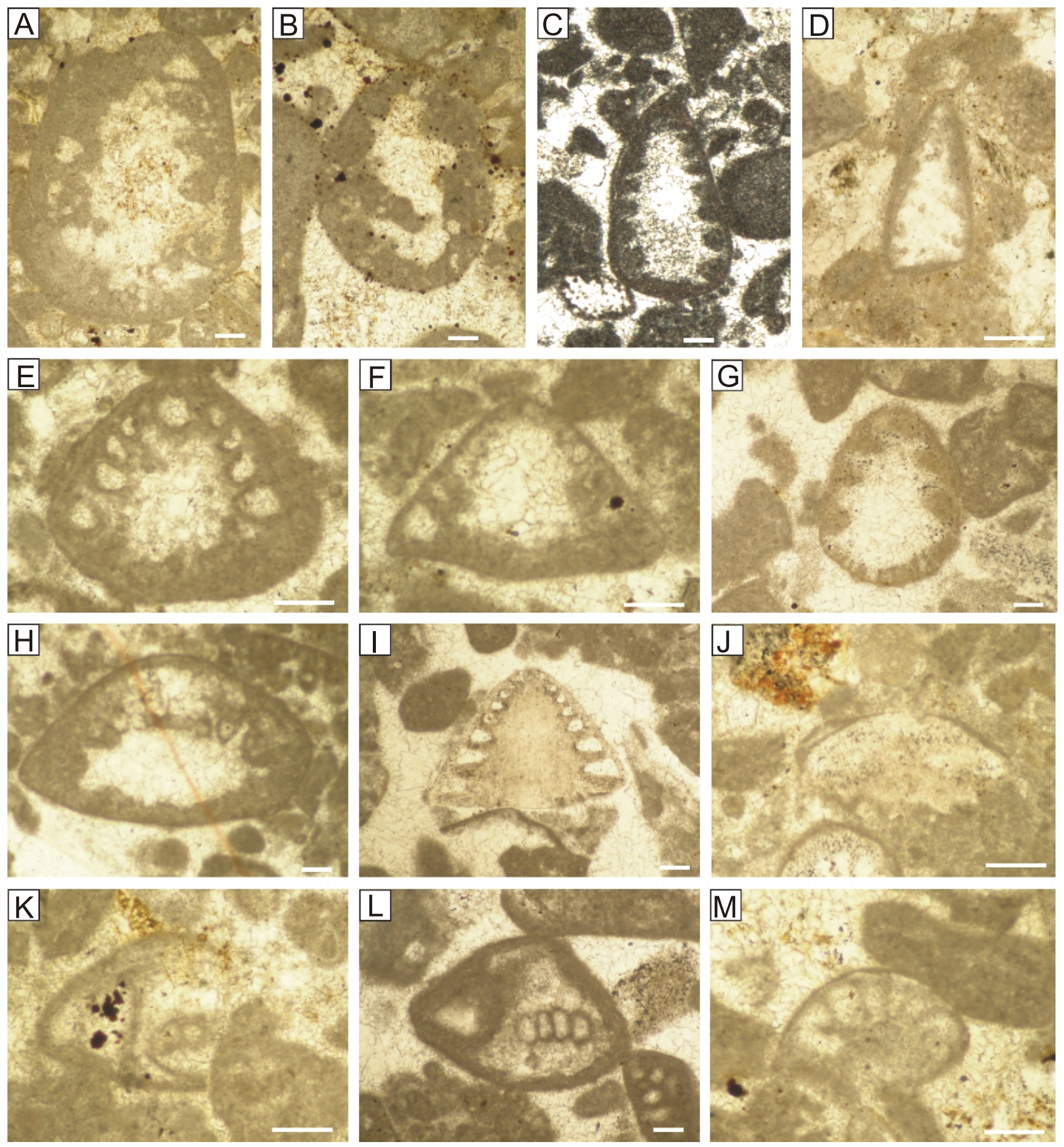

Fig. 19. Benthic foraminifera

A, B - Coscinoconus cf. delphinensis (Arnaud-Vanneau, Boisseau \& Darsac), sample 157; C - Coscinoconus cf. sagittaria (Arnaud-Vanneau, Boisseau \& Darsac), sample 163; D - Coscinoconus elongatus Leupold in Leupold \& Bigler, sample 134; E-G Coscinoconus alpinus Leupold, in Leupold \& Bigler: E, F - sample 157, G - sample 163; H - Coscinoconus sp., sample 157; I Neotrocholina valdensis Reichel, sample 163; J - Neotrocholina cf. friburgensis Guillaume \& Reichel, sample 157; K-M - Protopeneroplis ultragranulata (Gorbatchik): K - sample 157, L, M - sample 163; scale bar length is 100 microns 

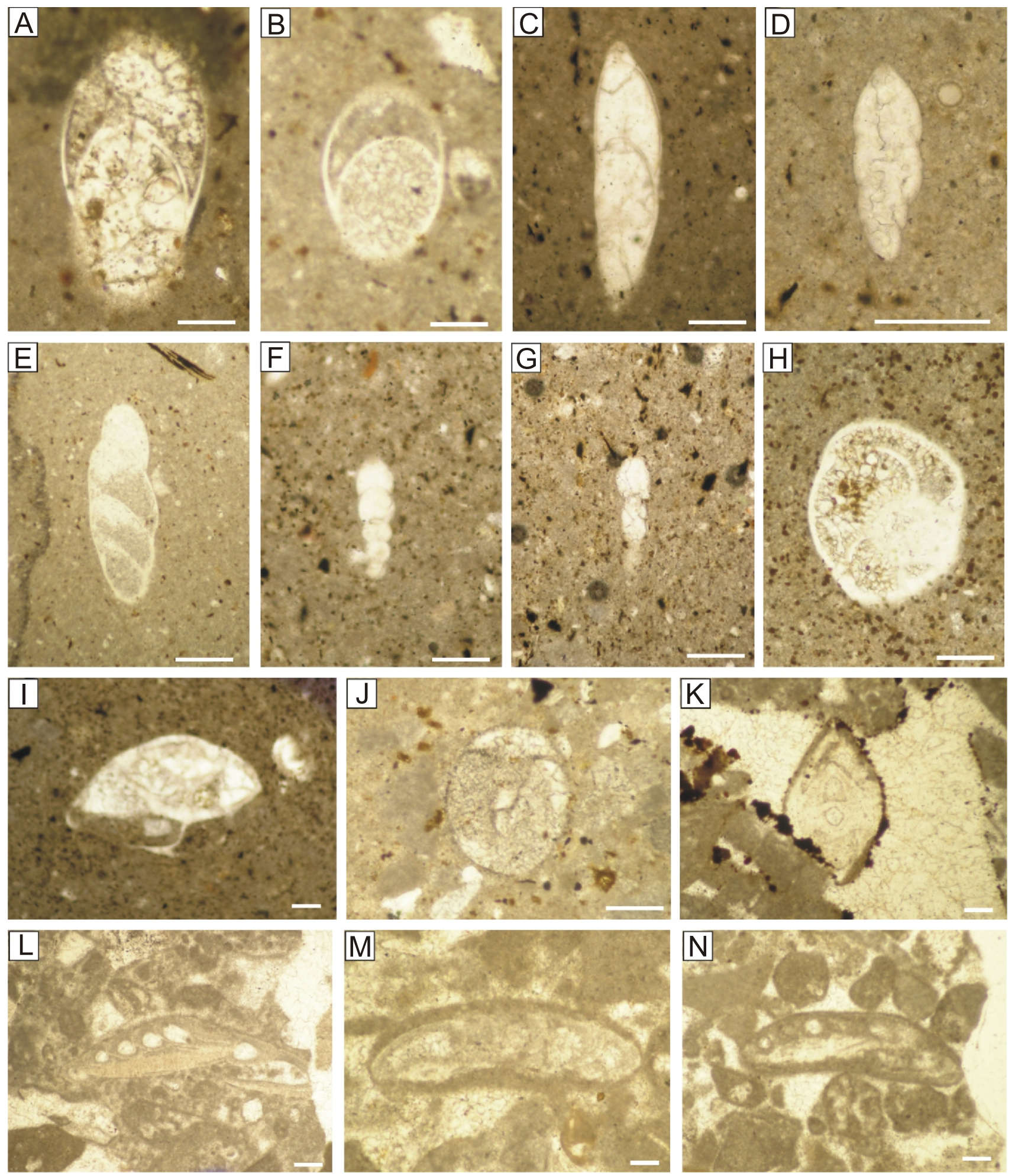

Fig. 20. Benthic foraminifera

A - Frondicularia sp., sample 154; B - Lingulina loryi (Berthelin), sample 152; C - Laevidentalina cf. nana (Reuss), sample 132; D Marginulinopsis sp., sample 160; E - Astacolus cf. calliopsis (Reuss), sample 123; F, G - Lingulonodosaria spp.: F - sample 131, G - sample 132; H, I - Epistomina cf. caracolla (Roemer): H - sample 118, I - sample 119; J - Quadrimorphina sp., sample 161; K - Lenticulina sp., sample 157; L-N - Mohlerina basiliensis (Mohler): L - sample 163, M, N - sample 157; scale bar length is 100 microns 

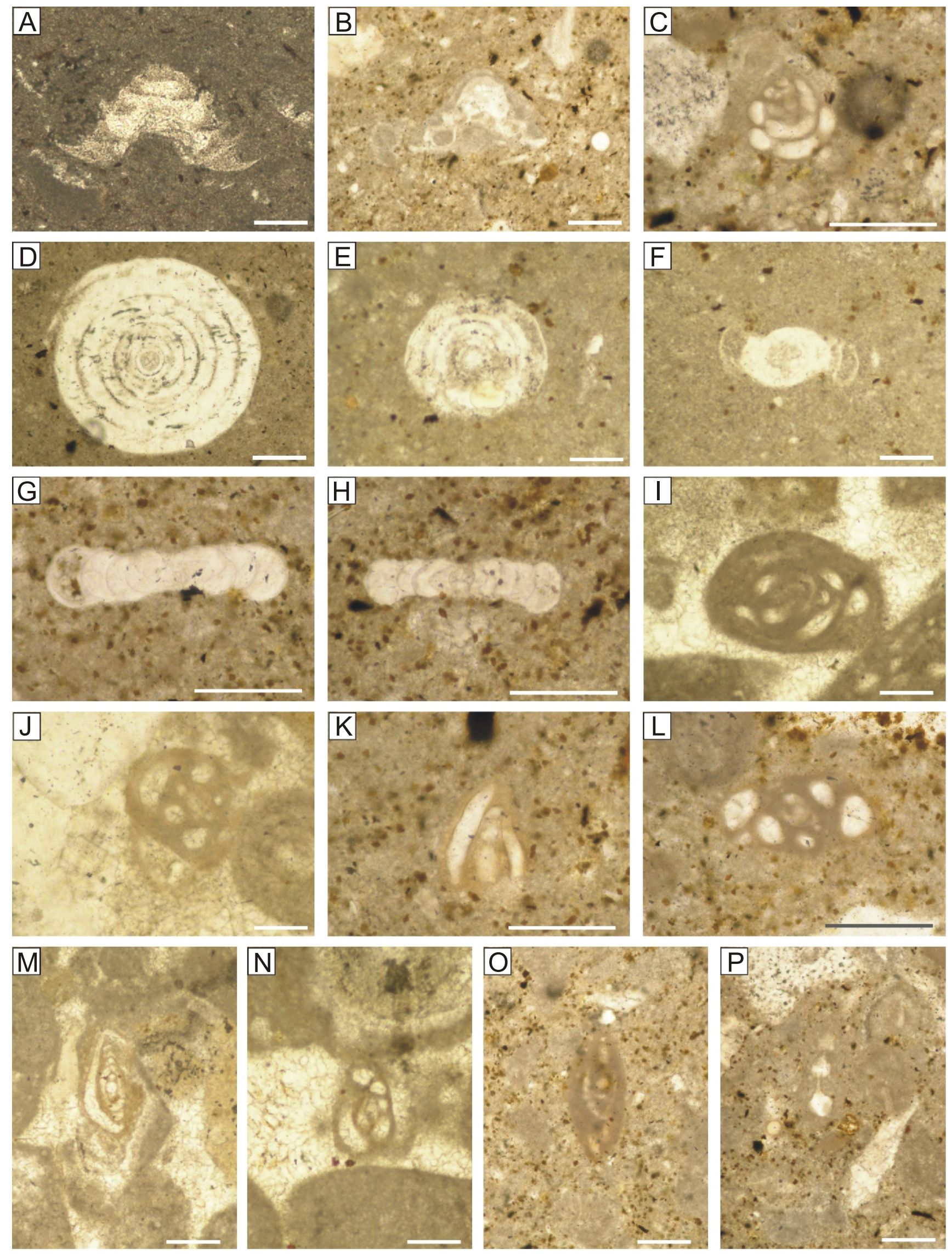

Fig. 21. Benthic foraminifera

A - Patellina turriculata Dieni \& Massari, sample 115; B - Patellina/Paalzowella sp., sample 132; C - Meandrospira favrei (Charollais, Brönnimann \& Zaninetti), sample 132; D, E - Spirillina minima Schacko: D - sample 160, E - sample 164; F - Miliospirella sp., sample 150;

G, H - Miliospirella sardoa Dieni \& Massari, sample 143; I, J - Quinqueloculina spp., sample 157; K-O - Ophthalmidium sp.: K - sample 131, L, M - sample 143, N, O - sample 157; P - Nodobacularia sp., sample 132; scale bar length is 100 microns 
Ranges of these taxa are as follows: Nautiloculina bronnimanni - Upper Tithonian (Bucur et al., 1996) to Upper Albian (Arnaud-Vanneau and Peybernés, 1978); Melathrokerion valserinensis Brönnimann \& Conrad - Berriasian (Darsac, 1983) to lowermost Aptian (Brönnimann and Conrad, 1967); Pseudocyclammina lituus Yokoyama - Oxfordian (Hughes, 2004; Velić, 2007) to Hauterivian (Canérot, 1984); Coscinophragma cribrosum (Reuss) - Upper Tithonian (Bucur et al., 1996) to Lower Aptian (Arnaud-Vanneau et al., 1987); Mohlerina basiliensis (Mohler) - Middle Jurassic (Middle Dogger - Weynschenk, 1956) to Valanginian (Schlagintweit and Ebli, 1999; Olszewska, 2005; Bucur and Săsăran, 2005; Krajewski and Olszewska 2007); Protopeneroplis ultragranulata (Gorbachik, 1971) - Upper Tithonian (Gorbachik, 1971; Bucur, 1997; Krajewski and Olszewska 2007) to Valanginian/Barremian (Bucur, 1997).

The uppermost samples in the section (samples 160-164) show a rich association of calcareous dinocysts and benthic foraminifera. Species of foraminifera and calcareous dinocysts are like those found in samples 155-159: Anchispirocyclina lusitanica, Protopeneroplis ultragranulata (Gorbatchik), Nautiloculina bronnimanni, Melathrokerion valserinensis Brönnimann \& Conrad, Pseudocyclammina lituus, Everticyclammina virguliana Maync, Coscinophraga macribrosum (Reuss) Mohlerina basiliensis (Mohler), Glomospira gordialis (Jones \& Parker), Quinqueloculina egmontensis, Lenticulina sp. Globulina sp. and a rich Coscinoconus-Neotrocholina assemblage, and also Conorboides hofkeri (Bartenstein \& Brand). Conorboides hofkeri is known from Berriasian to Valanginian strata (Dieni and Massari, 1966; Arkad'ev et al., 2006) and also from the Neocomian of the Canadian Atlantic margin (Gradstein et al., 1975).

In samples from the last two intervals some microfossils with unknown or uncertain systematic position were also found Lithocodium aggregatum Elliott, Bacinella irregularis Radoicic and Koskinobulina socialis Cherchi \& Schroeder. These results show some differences and contradictions as compared to previous published research data from Crimea, and also with species range data in the literature in general. Some species listed above are not typical for the early Berriasian, for example Meandrospira favrei, Patellina turriculata and Neotrocholina valdensis.

Kuznetsova and Gorbachik (1985), Fedorova (2004) and Arkad'ev et al. (2006) reported rich foraminiferan finds from the Ili Burni (= Cape Svyatogo Il'i) profile, and they defined a benthic foraminiferan biozonation. According to the first authors: "The species Protopeneroplis ultragranulatus and Siphoninella antiqua are index forms of the Lower Berriasian Protopeneroplis ultragranulatus-Siphoninella antiqua Zone". Based on the disappearance of the zonal index Anchispirocyclina lusitanica (Egg.) in the massive breccia (Section 4, Arkad'ev et al., 2006), Fedorova (2004) defined the Protopeneroplis ultragranulatus-Siphoninella antiqua Zone in the lowest part of the section just above the shore, a narrower definition of the eponymous unit as it was distinguished by Gorbachik (1971). However, all this notwithstanding, we have found well-preserved sections of Anchispirocyclina lusitanica in the lower Mayak Formation, in samples 157 and 163, and although all indications are that the specimens must be derived from sediments deposited in a shallow-marine setting, their condition suggests rapid transit and deposition in these early Berriasian deep-water beds. Though Anchispirocyclina Iusitanica should be Upper Tithonian, according to the cited previous studies, here it is associated with Berriasian ammonites and nannofossils.

\section{CALCAREOUS NANNOFOSSILS}

Calcareous nannofossil in the Theodosia $\mathrm{J} / \mathrm{K}$ profiles are rare to abundant, with poor to moderate preservation. Remains of heterococcoliths have often been observed. The dominance of Watznaueria, Cyclagelosphaera and Nannoconus is evident throughout the entire Dvuyakornaya and Mayak formations. Conusphaera mexicana mexicana is always present, and dominant, in the lli Burnu Gulley shore cliff. Polycostella senaria and Hexalithus strictus show locally high abundances (Ili Burnu path, Theodosia Boathouse Cliff).

Important nannofossil events used in delimitating the $\mathrm{J} / \mathrm{K}$ boundary, the FADs of the taxa Nannoconus wintereri, $N$. kamptneri minor and $N$. steinmanni minor have been recognized in the middle part of the Ili Burnu Gulley profile (samples 32 and 33). The onset of nannoconids larger than $10 \mu \mathrm{m}, N$. steinmannii steinmannii and $N$. kamptneri kamptneri, is in the lower Mayak Formation and these species continue up through the Middle Cliff and Boathouse sections. Selected calcareous nannofossils of the Dvuyakornaya and Mayak formations are shown in Figure 22. The distribution of stratigraphically useful nannofossil taxa is given in Appendix $1^{*}$ and their relativity to magnetozones in Figure 23.

\section{DVUYAKORNAYA FORMATION}

The succession of nannofossils in the Dvuyakornaya Formation was studied in the six sections just west of Ili Burnu.

1. Breccia section

The lowest studied interval has low-diversity nannofossil assemblages with moderate preservation, and some barren intervals. Dominance of Watznaueria species (Watznaueria britannica, W. barnesiae, W. fossacincta, W. manivitiae plus Cyclagelosphaera margerelii, Cycl. argoensis) is evident. Microstaurus chiastius occurs in every sample. Conusphaera mexicana mexicana and Cruciellipsis cuvillieri were determined in the upper part of the breccia section. Nannoconus infans, $N$. puer and $N$. compressus are present in samples 7,16 and 17 . The compositions of these assemblages indicate a Late Tithonian age. Redeposited specimens from pre-Tithonian Jurassic have been recognized (samples 6, 16 and 17).

\section{Gulley section}

Assemblages are characterized by the dominance of Watznaueria. Nannoconids are observed in samples 22, 25 and 37 (Nannoconus erbae, N. globulus minor, N. infans and $N$. puer). Significant FADs occur here: of $N$. wintereri (sample 31), of $N$. kamptneri minor and $N$. steinmannii minor (sample 33). Other nannoconids, N. globulus globulus and N. bronnimannii, are first documented in the upper part of the profile. Redeposition of older Jurassic nannofossils can again be recognized (e.g., sample 37).

\section{Path section}

Prevalence of $C$. margerelii and Watznaueria species is observed throughout this whole section. At the base of the profile an abundance of nannoconids and their continuity is recorded. They are mainly $N$. erbae, $N$. infans, $N$. compressus and, rarely, $N$. kamptneri minor, $N$. puer, $N$. steinmannii minor and $N$. wintereri. A high frequency of $N$. erbae was detected in samples 49,50 , and the species is common through the section. An increasing abundance of $P$. senaria, and $H$. strictus occurs from sample 49 to the top of the profile (sample 57). Rhagodiscus asper and Rotelapillus crenulatus appear consistently through-

\footnotetext{
* Supplementary data associated with this article can be found, in the online version, at doi: 10.7306/gq.1404
} 

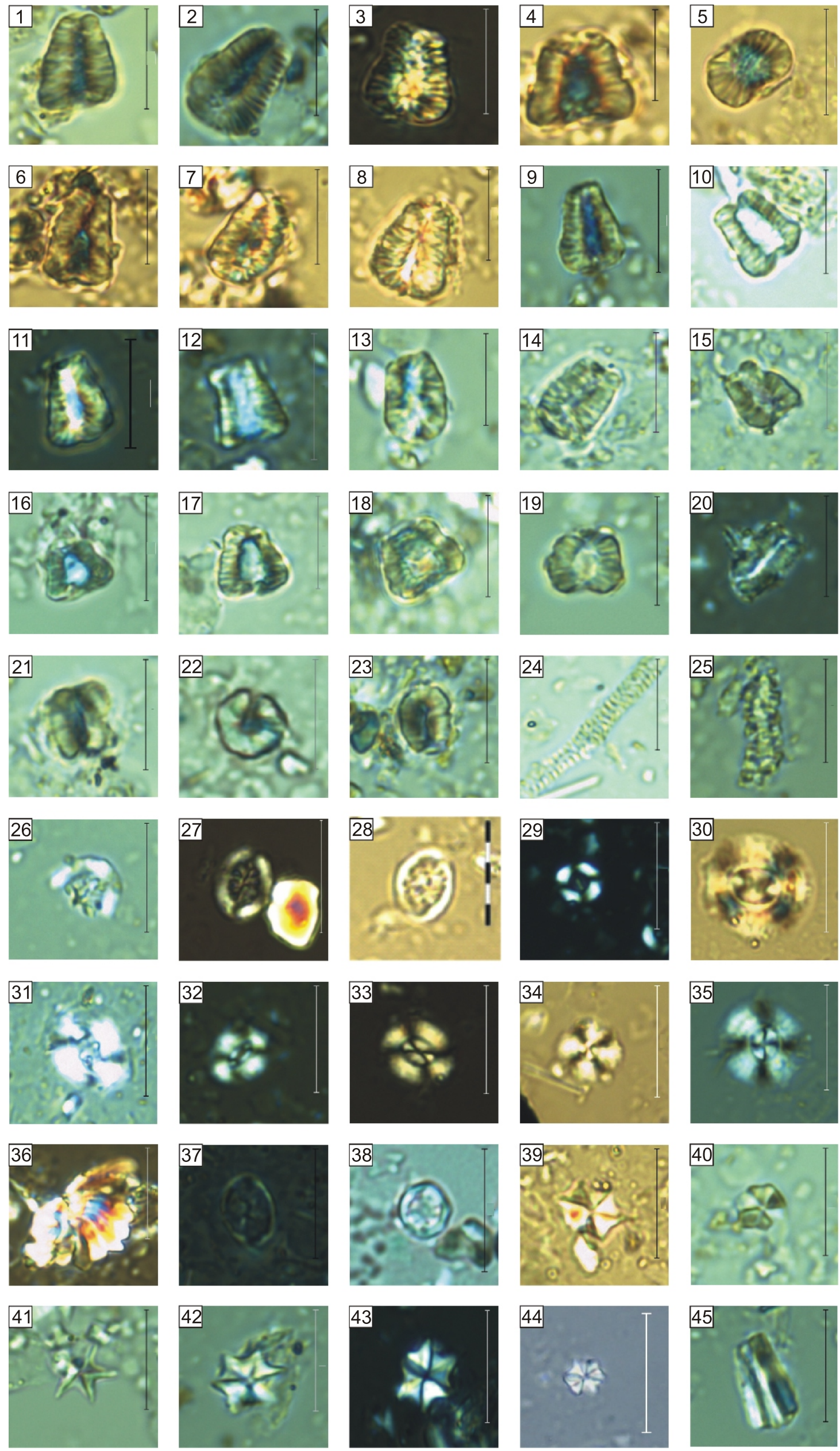
out the Path section. Redeposition of older Jurassic nannofossils can be recognized (e.g., sample 47).

4. Step section

The nannofossil association from the Step section includes exemplars of large Cyclagelosphaera species (C. deflandrei, $C$. argoensis), $R$. crenulatus, and nannoconids occur commonly, mainly $N$. globulus minor, less $N$. puer, $N$. wintereri, $N$. globulus globulus and N. kamptneri minor. Samples 61, 62, 64 and 71 are barren of nannofossils. Poor nannofossils were observed in samples 65, 75 and 76: W. barnesiae, W. britannica, $W$. manivitiae, C. argoensis, C. margerelii, Zeugrhabdotus embergeri, Z. fluxus, N. globulus minor and $N$. wintereri.

5. East facing cliff

Watznaueria and Cyclagelosphaera species dominate the studied assemblages. Decrease of nannoconids is observed. $N$. wintereri appears throughout the entire profile, and some exemplars of $N$. steinmannii minor, $N$. infans, $N$. puer and $N$. compressus were determined. $H$. strictus, Polycostella senaria and $R$. crenulatus are quite common. $R$. asper and species of Cretarhabdus are observed throughout.

6. Lighthouse Shack cliff

The calcareous nannofossils of this section comprise rich low-diversity assemblages with Watznaueria species dominant. In samples 87-95, assemblages are very impoverished, with low diversity or they are barren, with the exception of 91, which shows a slightly increased diversity. An increased abundance of $R$. crenulatus was recognised in the upper part of section. $N$. kamptneri minor could not be found in samples $86-100$, but was again recorded from 101-114. N. steinmannii minor is completely lacking in the Lighthouse shack profile.

\section{MAYAK FORMATION}

\section{A. Ili Burnu Lighthouse Cliff}

Sample 115 is barren, but $114-117$ contain dominant Watznaueria and Cyclagelosphaera species. N. wintereri, N. cf. wintereri, $N$. globulus minor and $N$. bronnimannii occur only rarely, as in 114 and 116, but more of them were detected in sample 117.

Nannofossils in samples 118 to 164 are common to abundant and generally well preserved. The assemblage is dominated either by nannoconids, in particular by species such as $N$. wintereri, $N$. cf. wintereri, $N$. kamptneri minor and $N$. bronnimannii and $N$. cf. bronnimannii or by Watznaueria species with C. margerelii (e.g., sample 130). Sometimes nannoconids are the main constituent in a sample. The first $10 \mu \mathrm{m}$ sized nannoconids ( $N$. steinmannii minor, sensu Casellato, 2010) were observed very seldomly in sample 138. Nannoconids $>10 \mu \mathrm{m}, \quad N$. kamptneri kamptneri and $N$. steinmannii steinmannii, appear in the upper part of the lower Mayak profile (sample 160).

In this interval, low-diversity assemblages with abundant 7 and $8 \mu \mathrm{m}$ sized nannoconids ( $N$. globulus minor, $N$. kamptneri minor, N. steinmannii minor and $N$. wintereri) appear, notably in sample 148.

B. "Middle Cliff"

Rich low-diversity assemblages are characterized by the dominance of nannoconids and Watznaueriaceae. The appearance of $N$. steinmannii minor with a size $\sim 8,9 \mu \mathrm{m}(179$, 181-188) and $N$. kamptneri minor (185, 186 and 188) mark an important change in the composition of calcareous nannofossil assemblages. N. steinmannii minor and $N$. kamptneri minor of an $8,9 \mu \mathrm{m}$ size prevail over scarce $10 \mu \mathrm{m}$ sized $N$. steinmannii minor (in samples 172, 177 and 187). Only one exemplar of $N$. steinmannii steinmannii >10 $\mu$ m was observed, in sample 172 .

C. Boathouse Cliff

A rich, low-diversity calcareous nannofossil assemblage with dominant. Watznaueriaceae and nannoconids are characteristic of this profile. Nannoconus steinmannii minor, $N$. kamptneri minor, $N$. bronnimannii and $N$. wintereri occur persistently in samples here.

The significant nannofossil feature identified in this part of the Mayak Formation is the rather continuous, but sporadic, occurrence of $10 \mu \mathrm{m}$ sized $N$. steinmannii steinmannii and $N$. kamptneri kamptneri (sensu Casellato, 2010) in samples 204, 205 and 218, and of specimens a little larger than $10 \mu \mathrm{m}$, of $N$. steinmannii steinmannii in samples 208, 219, 220 and 223, and $N$. kamptneri kamptneri in sample 203. Of other nannoliths, occasional $C$. mexicana mexicana appear, and $P$. senaria occurs rather frequently, in 220 to 222 . The magnetozone and calpionellid biozonal context for the FADs of stratigraphically useful nannofossil taxa at Theodosia, and elsewhere, may be seen in Figure 24.

\section{Fig. 22. Calcareous nannofossils}

1, 2 - Nannoconus steinmannii subsp. steinmannii Kamptner, 1931: 1 - sample 219, 2 - sample 223; 3 - N. kamptneri subsp. kamptneri Brönnimann, 1955, sample 203; 4 - N. wintereri Bralower \& Thierstein, in Bralower et al., 1989, sample 184; 5 - N. globulus subsp. minor (Brönnimann, 1955) Bralower in Bralower et al., 1989, sample 167; 6-8 - N. steinmannii subsp. steinmannii Kamptner, 1931, sample 162; 9-12 - N. kamptneri subsp. minor (Brönnimann, 1955) Bralower in Bralower et al., 1989: 9 - sample 138, 10 - sample 70, 11 - sample 47, 12 - sample 33; 13-15 - N. steinmannii subsp. minor (Kamptner, 1931) Deres and Achéritéguy, 1980: 13 - sample 43, 14 - sample 33, 15 sample 33; 16, 17 - N. wintereri Bralower \& Thierstein, in Bralower et al., 1989: 16 - sample 125, 17 - sample 31; 18 - N. bronnimannii, sample 134; 19 - N. globulus subsp. minor (Brönnimann, 1955) Bralower in Bralower et al., 1989, sample 138; 20 - N. compressus Bralower \& Thierstein in Bralower et al., 1989, sample 47; 21 - N. erbae Casellato 2010, sample 45; 22 - N. puer Casellato 2010, sample 22; 23 - N. infans Bralower in Bralower et al., 1989, sample 53; 24 - Faviconus multicolumnatus Bralower in Bralower et al., 1989, sample 58; 25 - N. dolomiticus Cita \& Pasquare, 1959, sample 42; 26 - Cruciellipsis cuvillieri (Manivit, 1966) Thierstein, 1971, sample 47; 27 - Cretarhabdus surirellus (Deflandre and Fert, 1954) Reinhardt, 1970, sample 84; 28 - Rhagodiscus asper (Stradner, 1963) Reinhardt, 1967, sample 78; 29 - Diazomatholithus lehmannii Noël, 1965, sample 218; 30 - Watznaueria manivitiae Bukry, 1973, sample 77; 31 - W. britannica (Stradner, 1963) Reinhardt, 1964, sample 7; 32 - W. fossacincta (Black, 1971) Bown in Bown \& Cooper, 1989, sample 219; 33 - W. barnesiae (Black in Black \& Barnes, 1959) Perch-Nielsen, 1968, sample 77; 34 - Cyclagelosphaera margerelii Noël, 1965, sample 16; 35 - Cyclagelosphaera argoensis Bown, 1992, sample 6; 36 - C. deflandrei (Manivit, 1966) Roth, 1973, sample 16; 37 - Umbria granulosa ssp. granulosa Bralower \& Thierstein in Bralower et al., 1989, sample 7; 38 - Rotelapillus crenulatus (Stover, 1966) Perch-Nielsen, 1984, sample 91; 39 - Hexalithus strictus Bergen, 1994, sample 84; 40 - H. noeliae Loeblich \& Tappan, 1966, sample 53; 41 - Micrantholithus parvistellatus Varol, 1991, sample 23; 42, 43 - Polycostella senaria Thierstein, 1971, sample 50; 44 - P. beckmannii Thierstein, 1971, sample 80; 45 - Conusphaera mexicana subsp. mexicana Trejo, 1969, sample 70; scale bar length is 10 microns 

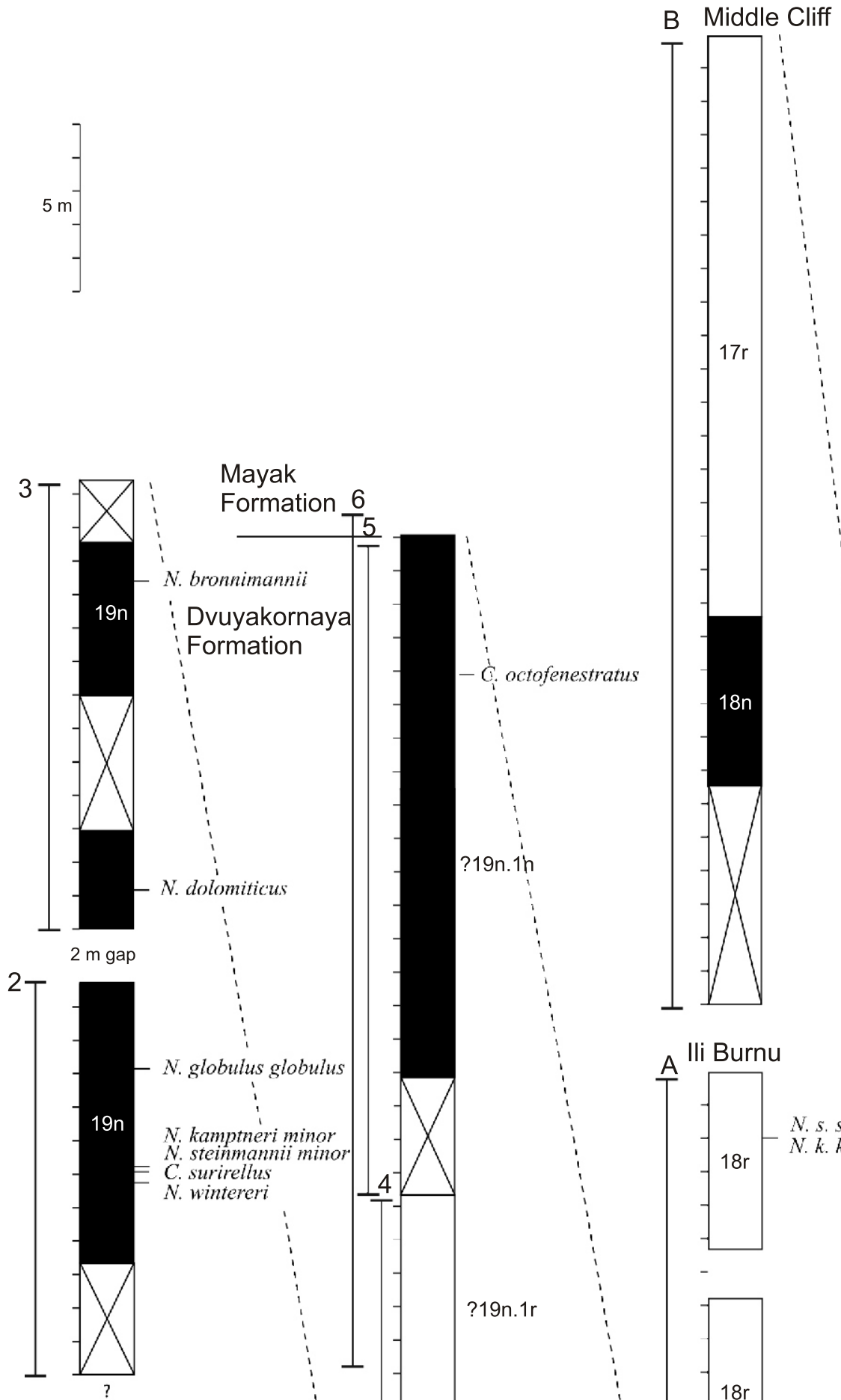

Boathouse

C Cliff

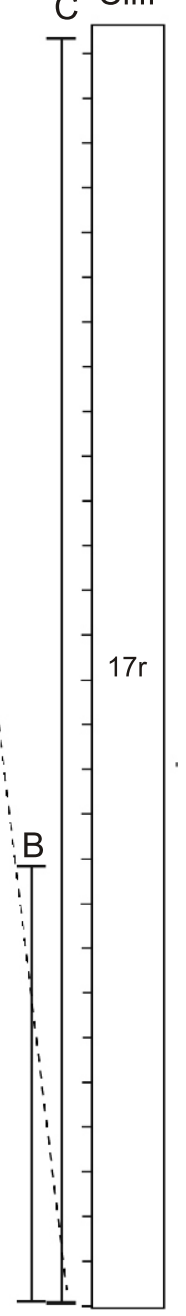

Fig. 23. Significant nannofossil FADs in the outcrops of the Dvuyakornaya and Mayak formations between Ili Burnu and Theodosia, calibrated with magnetozones 


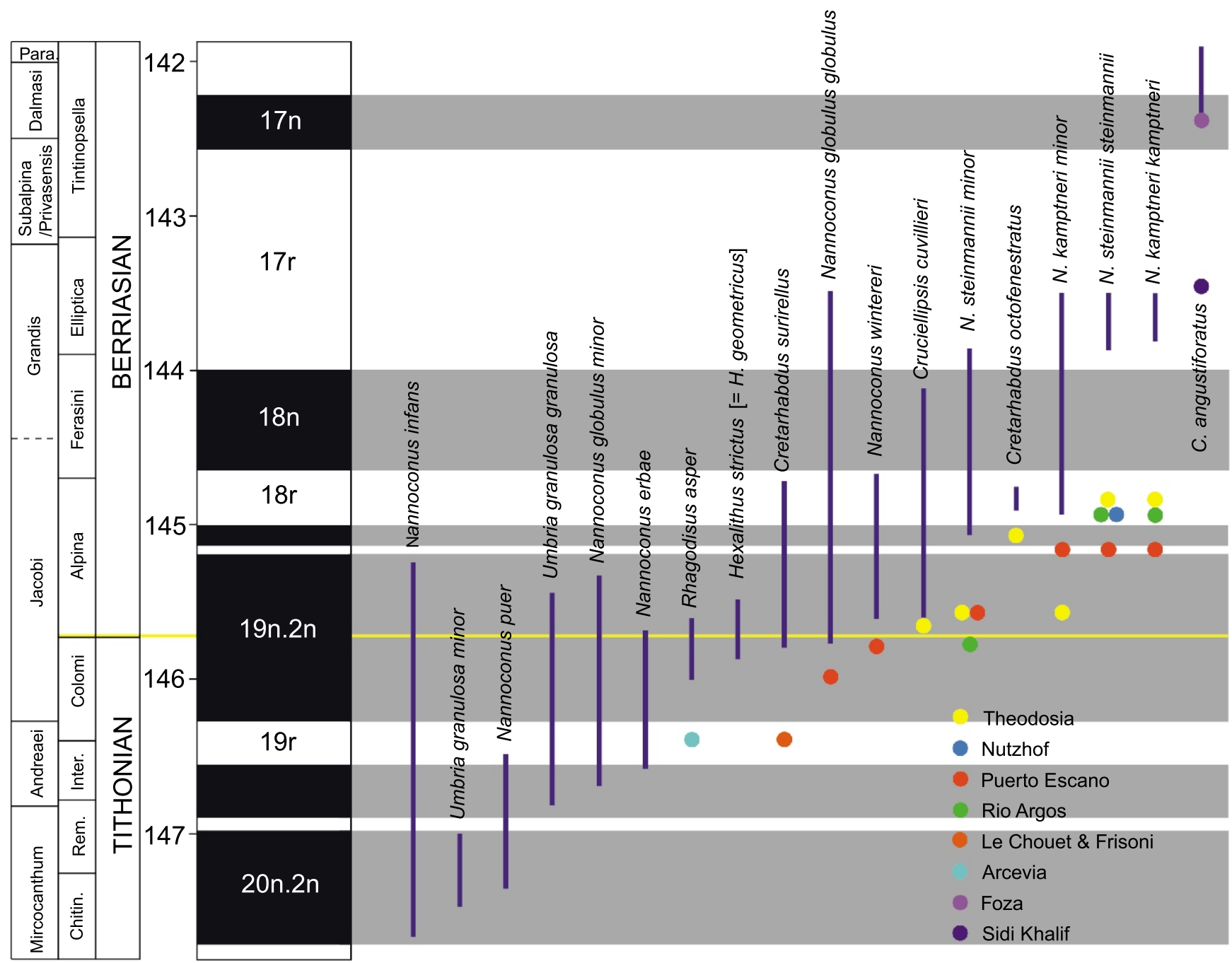

Fig. 24. Stratigraphically significant calcareous nannofossils at Theodosia placed in a wider Upper Tithonian to Lower Berriasian context, and calibrated with magnetozones and calpionellid biozones

Continuous vertical lines shows the range of FADs (not the total ranges of species) mostly in Italy (after Casellato, 2010); coloured spots represent recent records of FADs at new, lower, stratigraphic levels (after Speranza et al., 2005 - Arcevia; Lukeneder et al., 2010 - Nutzhof; Casellato, 2010 - Frisoni and Foza; Wimbledon et al., 2013 - Le Ghouet; Hoedemaeker et al., 2016 - Rio Argos; Svobodová and Košták, 2016 - Puerto Escaño; Gardin, pers. comm., 2015 - Sidi Khalif)

\section{CONCLUSIONS}

The discontinuous ammonite record of the studied interval is imperfect, but it allows us to identify components of two biozonal assemblages: those of the Jacobi and Grandis subzones of authors. The entire sequence, from the $2 \mathrm{~m}$ breccia (in middle Dvuyakornaya Formation) to the top of the Mayak Formation, is encompassed by only two subzones, but it has a thickness of $>160 \mathrm{~m}$, and a sedimentation rate of $\sim 50 \mathrm{~m}$ per My.

Our magnetostratigraphic interpretation has been outlined in a preliminary note (Bakhmutov et al., 2016). On the coast between the Ili Burnu Lighthouse and the outskirts of Theodosia, the data presented here allows us to identify two normally polarised intervals and two reversed, assigned to M19n, M18r, M18n and M17r, plus a possible M19n.1r (8 m or more thick; Figs. 8 and 24). M19n.2n and M19n.1r are identified in the uppermost Dvuyakornaya Formation above the massive $2 \mathrm{~m}$ breccia. The lowest part $(9.5 \mathrm{~m})$ of the Mayak Formation at lli Burnu falls within M19n.1n, with M18r overlying. Northwards from Ili Burnu, a thick (approaching $30 \mathrm{~m}$ ) M17r is identified in the middle to highest beds of the Mayak Formation, with M18n beneath (its base is obscured by talus).

These results are congruent with recent work at the Zavodskaya Balka clay pit by Guzhikov (in Arkad'ev et al., 2015), where M16r was identified at the bottom of the profile, crossing the Middle to Upper Berriasian junction (Occitanica-Boissieri zonal boundary). However, the magnetostratigraphy presented here does not coincide with other interpretations given by the same authors (Guzhikov et al., 2012: fig.14). Their magnetostratigraphy for the upper dark clays and microbreccias of the Dvuyakornaya Formation (from below the $2 \mathrm{~m}$ breccia upwards to $30 \mathrm{~m}$ above its base), has these beds assigned to M18r. The top part of the Dvuyakornaya Formation and the entire (incorrect) thickness of the micritic and marly Mayak Formation both were assigned to M18n. However, the lowest beds of the Mayak Formation at Ili Burnu are in an interval of reversed magnetic polarity that is here assigned to $\mathrm{M} 18 \mathrm{r}$; and the highest exposed beds of the formation, in the Boathouse section next to Theodosia, are assigned to M17r. 
The first appearances of species of significant calcareous nannofossils at Theodosia are shown in Figure 23. The appearances are not consistently equivalent to all records in western Tethys (Casellato, 2010; Schnabl et al., 2015), one reason being that in this preliminary study we did not sample beds below a level we believe to be assignable to the lower to middle part of M19n.2n. Thus some species here noted in M19n are above their normal FAD, such as Lithraphidites carniolensis which elsewhere has its FAD in M20n, similarly with $R$. asper, which elsewhere has its FAD in M19r. However, the FADs in M19n of $H$. strictus, C. cuvillieri, N. wintereri, N. steinmannii minor and $N$. kamptneri minor appear to be consistent with other regions. Figure 24 shows selected nannofossil FADs at Theodosia compared to recent results from other key $\mathrm{J} / \mathrm{K}$ localities.

$N$. globulus globulus first occurs in M19n.2n and Cretarhabdus octofenestratus in M19n.1n. The latter has been recorded elsewhere at its lowest in $\mathrm{M} 18 \mathrm{r}$, but the former is here in its 'correct' place in mid to low M19n.2n.

$N$. steinmannii steinmannii and $N$. kamptneri kamptneri occur in M18r at Ili Burnu, at a level different to some older Italian records, but closer to recent results (for instance from Puerto Escaño - Svobodová and Košták, 2016, agreeing with data from Nutzhof - Lukeneder et al., 2010), where the subspecies was also found in M18r.

The Berriasian Working Group of the ISCS in 2016 formally voted to use the base of the Alpina Subzone as the base of the Berriasian Stage: and one of the primary reasons for studying the thick southern Ukrainian sections had been to apply the standard calpionellid biozonation eastwards. However, calpionellid loricas in situ (i.e. in matrix, not in clasts) in the Theodosia sequence are very rare: they are badly preserved, their collars are often missing, and one may use only the lorica's caudal appendages for identification: thus it is hard to determine taxa. The Gulley section (locality 2) in the Dvuyakornaya Formation yields Crassicollaria Zone species. But the FAD of $N$. kamptneri minor occurs in the same profile, so this should be Alpina Subzone. Above, calpionellids are rarer. In two samples (136 and 115) in the lowest Mayak Formation, however, they are more frequent, with Calpionella alpina, C. elliptica, Tintinnopsella carpathica, Remaniella catalanoi and Lorenziella hungarica; and in the upper Mayak Formation, Remaniella colomi and Tintinnopsella carpathica are noteworthy (Boathouse section, sample 208). In summary, though no zonal boundaries can be fixed, taxa of the Alpina, Ferasini and Elliptica subzones of the Calpionella Zone can be identified between the $2 \mathrm{~m}$ breccia and the exposed top of the Mayak Formation.

Acknowledgements. This is a contribution to the efforts of the Berriasian Working Group of the International Subcommission on Cretaceous Stratigraphy (ICS). We thank our Ukrainian colleagues for their support and encouragement with fieldwork in Crimea. Also it is a pleasure to thank C. Casellato for her inputs and much discussion on nannofossils; and A. Sokolov and the museum of the A.P. Karpinsky Geological Research Institute (VSGEI), St. Petersburg, for much assistance with ammonite collections in their care. D. Reháková's study was supported by the Grant Agency of the Slovak Republic: APVV 14-0118, as well as VEGA Projects $2 / 0034 / 16$ and $2 / 0057 / 16$. We would like to extend sincere thanks to the S. Satolli, A. Pszczółkowski, J. Michalik and an anonymous reviewer for their useful reviews, and to J. Grabowski for his concerted efforts on our behalf.

\section{REFERENCES}

Altiner, D., 1991. Microfossil biostratigraphy (mainly Foraminifers) of the Jurassic-Lower Cretaceous carbonate successions in North-Western Anatolia (Turkey). Geologica Romana, 27: $167-215$

Andreini, G., Caracual, J.E., Parisi, G., 2007. Calpionellid biostratigraphy of the Upper Tithonian-Upper Valanginian interval in Western Sicily (Italy). Swiss Journal of Geosciences, 100: 179-198.

Arkad'ev, V.V., 2004. The first record of a Late Tithonian ammonite in the Feodosiya section of Eastern Crimea. Paleontological Journal, 38: 265-267.

Arkad'ev, V.V., 2016. Stratigraficheskaya skhema berriasskogo yarusa Gornogo Kryma. In: Obshchaya stratigraficheskaya shkala i metodicheskie problemy razrabotki regionalnykh stratigraficheskikh shkal Rossii (in Russian): 11-12. Materialy Mezhvedomstvennogo rabochego soveshchaniya Saint-Peterburg, 17-20 oktyabrya 2016

Arkad'ev, V.V, Bogdanova, T.N., 2004. The genus Berriasella (Ammonidea) from the Berriasian of mountainous Crimea. Stratigraphy and Geological Correlation, 12: 54-67.

Arkad'ev, V.V., Rogov, M.A., 2006. New data on Upper Kimmeridgian-Tithonian biostratigraphy and ammonites of eastern Crimea. Stratigraphy and Geological Correlation, 14: 185-199.

Arkad'ev, V.V., Atabekyan, A.A., Baraboshkin, E.Y., Bogdanova, T.N., 2000. Stratigraphy and ammonites of south-west Crimea. Palaeontographica A, 255: 85-128.

Arkad'ev, V.V., Bogdanova, T.N., Lobacheva, S.V., 2005. The new data on biostratigraphy of the Berriasian deposits of the Tonas river basin (Mountain Crimea) (in Russian). In: The Cretaceous
System of Russia: Problems of Stratigraphy and Palaeogeography (eds. V.V. Arkad'ev and V.A. Prozorovsky): 111-135. St. Petersburg.

Arkad'ev, V.V., Fedorova, A.A., Savel'eva, Y.N., Tesakova, E.M., 2006. Biostratigraphy of Jurassic-Cretaceous boundary sediments in eastern Crimea. Stratigraphy and Geological Correlation, 14: 302-330.

Arkad'ev, V.V., Bogdanova, T.N., Lysenko, N.I., 2007. Representatives of the genera Malbosiceras and Pomeliceras (Neocomitidae, Ammonoidea) from the Berriasian of the Crimean Mountains. Stratigraphy and Geological Correlation, 15 277-296.

Arkad'ev, V.V., Bagaeva, M.I., Guzhikov, A.Y., 2010. Melovaya sistema Rossii i blizhnego zarubezhia: problemy stratigrafii i paleogeografii (in Russian). In: Materialy Pyatogo Vserossiyskogo soveshchaniyaeds (eds. E.Y. Baraboshkin and I.V. Blagoveshchenskii): 49-53. Ul'yanovsk, UIGU.

Arkad'ev, V.V., Bogdanova, T.N., Guzhikov, A.Y., Lobacheva, S.V., Mishkyna, N.V., Platonov, E.S., Savelyeva, Y.N., Shurekova, O.V., Yanin, B.T., 2012. Berriasian stage of the Mountainous Crimea (in Russian with English summary). LEMA, St. Petersburg.

Arkad'ev, V.V., Guzhikov, A.Y., Savelieva, J.N., Feodorova, A.A., Shurekova, O.V., Bagaeva, M.I., Grishenko, V.A., Manikin, A.G., 2015. New data on bio- and magnetostratigraphy of the Upper Berriasian section Zavodskaya balka (Eastern Crimea, Feodosiya) (in Russian with English summary). Vestnik of St. Petersburg University, Series 7, Geology, Geography, 4: 4-36.

Arnaud-Vanneau, A., Peybernés, B., 1978. Les representants eocretaces du genre Nautiloculina Mohler, 1938 (Foraminifera, 
fam. Lituolidae?) dans les chaines subalpines septentrionales (Vercors) et les Pyrenees Franco-Espagnoles. Revision de Nautiloculina cretacea Peybernés, 1976 et description de Nautiloculina bronnimanni n. sp. Geobios, 11: 67-81.

Arnaud-Vanneau, A., Arnaud, H., Adatte, Th., Argot, M., Rumley, G., Thieuloy, J.-P., 1987. The Lower Cretaceous from the Jura Platform to the Vocontian Basin (Swiss Jura, France). Field trip guide book, Excursion D, III International Cretaceous Symposium, Tubingen

Arnaud-Vanneau, A., Boisseau, T., Darsac, C., 1988. Le genre Trocholina Paalzow 1922 et ses principals especes au Crétacé. Revue de Paléobiologie, Spec. vol., 2: 353-377.

Auer, M., Gawlick, H.-J., Suzuki, H., Schlagintweit, F., 2009. Spatial and temporal development of siliceous basin and shallow-water carbonate sedimentation in Oxfordian (Northern Calcareous Alps). Facies, 55: 63-87.

Bakhmutov, V.G., Casellato, C.E., Halásová, E., Ivanova, D.K., Reháková, D., Wimbledon, W.A.P., 2016. Bio- and magnetostratigraphy of the Upper Tithonian-Lower Berriasian in southern Ukraine. XIIth Jurassica Conference - April 2016: 97-100. Slovak Academy of Sciences.

Bogdanova, T.N., Arkad'ev, V.V., 2005. Revision of species of the ammonite genus Pseudosubplanites from the Berriasian of the Crimean Mountains. Cretaceous Research, 26: 488-506.

Bogdanova, T.N., Lobacheva, S.V., Prozorovskii, V.A., Favorskaya, T.A., 1981. O raschlenenii berriasskogo yarusa Gornogo Kryma (in Russian). Vestnik Leningradskogo Universiteta, seria geologia i geografia, 1: 5-14

Bogdanova, T.N., Lobacheva, S.V., Prozorovskii, V.A. Favorskaya, T.A., 1984. Berrias Vostochnogo Kryma i granitsy jury i mela (in Russian) In: The Jurassic and Cretaceousn boundary stages: 28-35. Nauka, Moscow.

Borza, K., 1984. The Upper Jurassic-Lower Cretaceous parabiostratigraphic scale on the basis of Tintinninae, Cadosinidae, Stomiosphaeridae and other microfossils from the West Carpathians. Geologický Zborník Geologica Carpathica 35: $539-550$.

Bralower, T.J., Monechi, S., Thierstein, H.R., 1989. Calcareous nannofossils zonation of the Jurassic-Cretaceous boundary interval and correlations with the Geomagnetic Polarity Timescale. Marine Micropalaeontology, 14: 153-235.

Brönnimann, P., Conrad, M.A., 1967. Cinquième note sur les foraminifèrs du Crétacé inférieur de la région genevoise. Melathrokerion valserinensis n. gen., n. sp., un foraminifère nouveau du Barrémien à faciès urgonien dans le Jura français. Compte Rendu des Seances de la Societe de Physique et d'Histoire Naturelle de Geneve, 1: 129-151.

Bucur, I.I., 1988. Les foraminifères du Crétacé inférieur (Berriasian-Hauterivian) de la zone de Reşiţa-Moldova Nouă (Carpathes Méridionales, Roumanie). Remarques biostratigraphiques. Revue de Paléobiologie, Spec. Vol., 2 379-389.

Bucur, I.I., 1997. Representatives of the genus Protopeneroplis (Foraminifera) in the Jurassic and Lower Cretaceous deposits in Romania. Comparisons with other regions of the Tethyan area Acta Palaeontologica Romaniae, 1: 65-71.

Bucur, I.I., Săsăran, E., 2005. Micropaleontological assemblages from the Upper Jurassic-Lower Cretaceous deposits of Trascău Mountains and their biostratigraphic significance. Acta Palaeontologica Romaniae, 5: 27-38.

Bucur, I.I., Conrad, M., Radoičić, R., 1995. Foraminifers and calcareous algae from Valanginian Limestones in the Jerma river canyon, Eastern Serbia. Revue de Paléobiologie, 14: 349-377.

Bucur, I.I., Senowbari-Daryan, B., Abate, B., 1996. Remarks on some foraminifera from the Upper Jurasic (Tithonian) reef limestone of Madonie Mountains (Sicily). Bollettino della Società Paleontologica Italiana, 35: 65-80.

Bucur, I.I., Koch, R., Kirmaci, Z., Tasli, K., 2004. Foraminifères du Jurassique supérieur et du Cretacé inférieur (Calcaire de Berdiga) de Kircaova (région de Kale-Gümüshane, NE Turquie) Revue de Paléobiologie, 23: 209-225.
Bucur, I., Beleš, D., Sasaran, E., Balica, C., 2010. New data on facies development and micropaleontology of the eastern margin of the Getic Carbonate Platform (South Carpathians, Romania): case study of the Mateiaş Limestone. Studia Universitatis Babeş-Bolyai, Geologia, 55: 33-41.

Canérot, J., 1984. Fluctuations marines et evolution biologique: exemple du Neocomien des Iberides orientales (Espagne). In: Bentos'83, 2nd Int. Symp. Benthic Foraminifera, Pau, April 1983: $131-139$.

Casellato, C.E., 2010. Calcareous nannofossil biostratigraphy of Upper Callovian-Lower Berriasian successions from Southern Alps, North Italy. Rivista Italiana di Paleontologia e Stratigrafia, 116: $357-404$

Chadima, M., Hrouda, F., 2006. Remasoft 3.0 - a user-friendly paleomagnetic data browser and analyzer. Abstracts of the 10th "Castle Meeting". New Trends in Geomagnetism. Castle of Valtice, September 3-8th, 2006. Travaux Géophysiques, 27: 20-21

Çinku, M.C., Hisarli, Z.M., Orbay, N., Ustaömer, T., Hirt, A.M. Kravchenko, S., Rusakov, O., Sayin, N., 2013. Evidence of Early Cretaceous remagnetization in the Crimean Peninsula: a palaeomagnetic study from Mesozoic rocks in the Crimean and Western Pontides, conjugate margins of the Western Black Sea. Geophysical Journal International, 195: 821-843.

Darsac, C., 1983. La plate-forme berriaso-valanginienne du Jura méridional aux massifs subalpins (Ain, Savoie). Sédimentologie, minéralogy, stratigraphie, paléogéographie, micropaléontology. Thése 3 e cycle, Université des Sciences et Médicale Grenoble.

Dieni, I., Massari, F., 1966. Precisazioni sull'etŕ di alcuni conglomerati affioranti presso Siniscola, Orosei e Dorgali (Sardegna orientale). Accademia nazionale dei Lincei, Rendiconti della Classe di Scienze fisiche, matematiche e naturali, 8, 39: 205-211.

Druschits, V.V., 1975. The Berriasian of the Crimea and its stratigraphical relations, Colloque sur la limite Jurassique-Crétacé, Lyon, Neuchâtel, Septembre 1973. Memoires de Bureau de Recherches Géologiques et Minières de France, 86: 337-341.

Dulub, V., Terestschuk, A., 1964. Predstaviteli miliolid iz yurskikh otlozheniy yugo-zapadnoy okrainy Russkoy platformy (in Russian). Trudy Ukrainskogo Nauchno-Issledovatelskogo Geologo-Razvedochnogo Instituta (NIGRI), 9: 106-111.

Einsele, G., 1991. Submarine mass flow deposits and turbidites. In: Cycles and Events in Stratigraphy (eds. G. Einsele, W. Ricken and A. Seilacher): 313-339. Springer, New York.

Embry, A.F., Klovan, J.E., 1971. A late Devonian reef tract on northeastern Banks Island, N.W.T. Bulletin of Canadian Petroleum Geology, 19: 730-781.

Fedorova, A.A., 2004. Opornyye razrezy pogranichnykh otlozheniy yury i mela Kryma kak osnova dlya detalizatsii raschleneniya i korrelyatsii produktivnykh tolshch Kaspiyskogo shelfa. In: Stratigrafiya neftegazonosnykh basseynov Rossii: 61-80. Nedra, St. Petersburg.

Fisher, N.I., Lewis, T., Embleton, B.J.J., 1987. Statistical Analysis of Spherical Data. Cambridge University Press, Cambridge.

Flügel, E., 2004. Microfacies of Carbonate Rocks. Springer, Berlin.

Frau, C., Bulot, L.G., Reháková. D., Wimbledon, W.A.P., Ifrim, C., 2016. Revision of Berriasella jacobi Mazenot, 1939 and its consequences for the biostratigraphy of the Berriasian Stage. Cretaceous Research, 66: 1-21.

Glushkov, A.Y., 1997. On the first record of the index-species of thee lower zone of the Berriasian Stage in Crimea (in Russian with English summary). Bulletin St. Petersburg State University Series, 7: 90-93.

Gorbachik, T., 1971. On Early Cretaceous foraminifera of the Crimea (in Russian with English summary). Voprosy Micropaleontologii, 14: 125-139.

Gorbachik, T.N., Drushchits, V.V., Yanin, B.T., 1970. Osobennosti berriasskogo i valanzhinskogo basseynov Kryma i ikh naseleniya (in Russian). Vestnik Moskovskogo Gosudarstvennogo Universiteta, Seria Geologia, 3: 16-25. 
Grabowski, J., Pszczółkowski, A., 2006. Magneto- and biostratigraphy of the Tithonian-Berriasian pelagic sediments in the Tatra Mountains (central Western Carpathians, Poland) sedimentary and rock magnetic changes at the Jurassic/Cretaceous boundary. Cretaceous Research, 27: 398-417.

Grabowski, J., Lakova, I., Petrova, S., Stoykova, K., Ivanova, D., Wójcik-Tabol, P., Sobień, K., Schnabl, P., 2016. Paleomagnetism and integrated stratigraphy of the Upper Berriasian hemipelagic succession in the Barlya section Western Balkan, Bulgaria: implications for lithogenic input and paleoredox variations. Palaeogeography, Palaeoclimatology, Palaeoecology, 461: 156-177.

Gradstein, F.M., Williams, G.L., Jenkins, W.A.M., Ascoli, P., 1975. Mesozoic and Cenozoic stratigraphy of the Atlantic continental margin, eastern Canada. Canadian Society of Petroleum Geologists Memoir, 4: 103-131.

Gradstein, F.M., Ogg, J.G., Schmitz, M.D., Ogg, G.M., eds., 2012 The Geologic Time Scale 2012. Elsevier, Boston, USA.

Granier, B., Bucur, I.I., 2011. Stratigraphic ranges of some Tithonian-Berriasian benthic foraminifers and Dasycladales. Re-evaluation of their use in identifying this stage boundary in carbonate platform settings. Boletín del Instituto de Fisiografía y Geología, 79-81: 9-10.

Gutowski, J., Popadyuk, I.V., Olszewska, B., 2005. Stratigraphy and facies development of the Upper Tithonian-Lower Berriasian Niżniów Formation along the Dniester River (Western Ukraine). Geological Quarterly, 49 (1): 45-52.

Guzhikov, A.Y., Arkad'ev, V.V., Baraboshkin, E.Y., Bagaeva, M.I., Piskunov, V.K., Rud'ko, S.V., Perminov, V.A., Manikin, A.G. 2012. New sedimentological, bio-, and magnetostratigraphic data on the Jurassic-Cretaceous boundary interval of Eastern Crimea (Feodosiya). Stratigraphy and Geological Correlation, 20: 261-294.

Hoedemaeker, P.J., Jannsen, N.M.M., Casellato, C.E., Gardin, S., Rehakova, D., Jamrichova, M., 2016. Jurassic-Cretaceous boundary in the Río Argos succession (Caravaca, SE Spain). Revue de Paléobiologie, 35: 111-247.

Holbourn, A.E.L., Kaminski, M.A., 1997. Lower Cretaceous deep-water benthic foraminifera of the Indian Ocean. Grzybowski Foundation Special Publication, 4: 1-172.

Houša, V., Krs, M., Krsová, M., Man, O., Pruner, P., Venhodová, D., 1999. High-resolution magnetostratigraphy and micropaleontology across the $\mathrm{J} / \mathrm{K}$ boundary strata at Brodno near Žilina, western Slovakia: summary results. Cretaceous $\mathrm{Re}$ search, 20: 699-717.

Houša, V., Krs, M., Man, O., Pruner, P., Venhodová, D., Cecca, F., Nardi, G., Piscitello, M., 2004. Combined magnetostratigraphic, palaeomagnetic and calpionellid investigations across Jurassic/Cretaceous boundary strata in the Bosso Valley, Umbria, central Italy. Cretaceous Research, 25: 771-785.

Hughes, G.W., 2004. Palaeoenvironmental and sequence stratigraphic implication of Pseudocyclammina lituus events in the Upper Jurassic (Oxfordian) Hanifa Formation of Saudi Arabia. Grzybowski Foundation Special Publication, 8: 209-216.

Ivanova, D., 2000. Middle Callovian to Valanginian microfossil biostratigraphy in the West Balkan Mountains, Bulgaria (SE Europe). Acta Palaeontologica Romaniae, 2: 231-236.

Ivanova, D., Kołodziej, B., 2010. Upper Jurassic-Lower Cretaceous foraminifers from Štramberk type limestones of South Poland. Studia Universitatis Babes-Bolyai, Geologia, 55: 3-31.

Ivanova, D., Kołodziej, B., Koleva-Rekalova, E., Roniewicz, E., 2008. Oxfordian to Valanginian palaeoenvironmental evolution on the western Moesian Carbonate Platform: a case study from SW Bulgaria. Annales Societatis Geologorum Poloniae, 78: 65-90.

Jelínek, V., 1973. Precision A.C. bridge set for measuring magnetic susceptibility and its anisotropy. Studia Geophysica et Geodaetica, 17: 36-48.

Jones, R.W., Wonders, A.A.H., 1992. Benthic foraminifers and paleobathymetry of Barrow Group (Berriasian-Valanginian) deltaic sequences, sites 762 and 763, Northwest shelf, Austra- lia. Proceedings of the Ocean Drilling Program, Scientific Results, 122: $557-568$.

Kirschvink, J.L., 1980. The least squares line and plane and the analysis of palaeomagnetic data. Geophysical Journal of the Royal Astronomical Society, 62: 699-718.

Krajewski, M., Olszewska, B., 2007. Foraminifera from the Late Jurassic and Early Cretaceous carbonate platform facies of the southern part of the Crimea Mountains; Southern Ukraine. Annales Societatis Geologorum Poloniae, 77: 291-311.

Kukoč, D., Goričan, S., Košir, A., 2012. Lower Cretaceous carbonate gravity-flow deposits from the Bohinj area (NW Slovenia): evidence of a lost carbonate platform in the Internal Dinaride. Bulletin Sociètè Géologique de France, 183: 383-392.

Kuvaeva, S.B., Yanin, B.T., 1973. Palinologicheskaya kharakteristika nizhnemelovykh otlozheniy Gornogo Kryma (in Russian). Vestnik Moskovskogo Gosudarstvennogo Universiteta, seria geologia, 5: 49-57.

Kuznetsova, K., 1974. Distribution of benthonic foraminifera in Upper Jurassic and Lower Cretaceous deposits at Site 261, DSDP LEG 27, in the Eastern Indian Ocean. Initial Report of Deep Sea Drilling Project, 27: 673-681.

Kuznetsova, K.I., Gorbachik, T.N., 1985. Upper Jurassic and Lower Cretaceous stratigraphy and foraminifers of the Crimea (in Russian with English summary). Transactions, Geological Institute, Academy Science USSR, 395.

Kvantaliani, I.V., 1999. Berriasian cephalopods of the Crimea and the Caucasus (in Russian). Proceedings of the Georgian Academy of Sciences Geological Institute, New Series, 112: 1-188.

Kvantaliani, I.V., Lysenko N.I., 1979. K voprosu zonalnogo raschleneniya berriasa Kryma (in Russian). Soobshchenia Akademii Nauk Gruzinskoy SSR, 94: 629-632.

Lakova, I., Petrova S., 2013. Towards a standard Tithonian to Valanginian calpionellid zonation of the Tethyan Realm. Acta Geologica Polonica, 63: 201-221.

Lakova, I., Stoykova, K., Ivanova, D., 1999. Calpionellid, nannofossils and calcareous dinocyst bioevents and integrated biochronology of the Tithonian to Valanginian in the West Balkan Mountains, Bulgaria. Geologica Carpathica, 50: 151-168.

Lakova, I., Tchoumatchenko, P., Ivanova, D., Koleva-Rekalova, E., 2007. Callovian to Lower Cretaceous pelagic carbonates in the West Balkan Mountains (Komshtitsa and Barlya sections): integrated biostratigraphy and microfacies. Geologica Balcanica, 36: 81-89.

Le Hégarat, G., 1973. Le Berriasien du sud-est de la France. Université Claude Bernard, Lyon. Thése, 149: 1-576.

Linetskaya, L.V., 1968. Mezozoiski tyntynidy Krymu. (in Ukrainian) Dopovidi Akademii Nauk URSR Seriia, B4: 308-310.

Linetskaya, L.V., 1969. Significance of Tintinnoidea (Infusoria) for the stratigraphy of the Mesozoic of the European part of Tethys (in Russian). Soviet Geology, 10: 39-47.

Leupold, W., Bigler, H., 1936. Coscinoconus, eine neue Foraminiferenform aus Tithon-Unterkreide-Gesteinen der helvetischen Zone der Alpen. Eclogae Geologicae Helvetiae, 28: 606-624.

Lobacheva, S.V., Smirnova, T.N., 2006. Berriasian (Lower Cretaceous) brachiopods from the Crimea. Stratigraphy and Geological Correlation, 14: 642-654.

Loeblich, A., Tappan, H., 1987. Foraminiferal Genera and Their Classification. 1. Text and Indices, New York (Van Nostrand).

Lukeneder, A., Halasova, E., Kroh, A., Mayrhofer, S., Pruner, P., Reháková, D., Schnabl, P., Sprovieri, M., Wagreich, M., 2010. High resolution stratigraphy of the Jurassic-Cretaceous boundary interval in the Gresten Klippen Belt (Austria). Geologica Carpathica, 61: 365-381.

Man, 0., 2008. On the identification of magnetostratigraphic polarity zones. Studia Geophysica et Geodaetica, 52: 173-186.

Mancinelli, A., Coccia, B., 1999. Le Trocholine die sedimenti mesozoici di piattaforma carbonatica dell'Appennino centro-meridionale (Abruzzo e Lazio). Revue de Paléobiologie, 18: $147-171$.

Matlaj, L., 2011. Nannoplankton biostratigraphy subdivision across the Jurassic-Cretaceous boundary in the Eastern Crimea's de- 
posits. Report National Academy of Sciences of Ukraine, 1 106-112.

Matveev, A.V., 2009. Tithonian calcareous nanoplankton of the Eastern Crimea. In: Iskopaemaya fauna i flora Ukrainy: paleoekologicheskiye i stratigraficheskiye aspekty (in Ukrainian with English summary): 104-107. Biostratigrafiya, paleontologiya. Mezozoy. Inst. Geol. Nauk NAN Ukrainy.

Matyszkiewicz, J., Słomka, T., 1994. Organodetrital conglomerates with ooids in the Cieszyn Limestone (Tithonian-Berriasian) of the Polish Flysch Carpathians and their palaeogeographic significance. Annales Societatis Geologorum Poloniae, 63 211-248.

Mazenot, G., 1939. Les Palaeophoplitidae tithoniques et berriasiens du sud-est de la France. Mémoires de la Société Géologique de France, Nouvelle Série, 41: 1-303.

Meijers, M.J.M., Vrouweb, B., van Hinsbergen, D.J.J., Kuipera, K.F., Wijbrans, J., Davies, G.R., Stephenson, R.A. Kaymakcý, N., Matenco, L., Saintot, A., 2010. Jurassic arc volcanism on Crimea (Ukraine): implications for the paleosubduction zone configuration of the Black Sea region. Lithos, 119: 412-426.

Muratov, M.V., 1937. Geologicheskiy ocherk vostochnoy okonechnosti Krymskikh gor (in Russian). Trudy MGRI, 7 21-122.

Neagu, T., 1970. The genus Meandrospira (Foram.) from Lower Cretaceous strata in Romania. Senckenbergiana Lethaea, 51 $411-415$.

Neagu, T., 1984. Nouvelles données sur la morphologie du test, sur la systematique et la nomenclature des Miliolidés agatistheques du Mésozoique. Revista Española de Micropaleontología, 16 75-90.

Neagu, T., 1985. Berriasian-Valanginian miliolid fauna of the Southern Dobrogea (Romania). Revista Española de Micropaleontología, 17: 201-220.

Neagu, T., 1986. Barremian-Lower Aptian miliolid fauna in Southern Dobrogea (Romania). Revista Española de Micropaleontología, 18: 313-348.

Neagu, T., 1994. Early Cretaceous Trocholina group and some related genera from Romania. Part I. Revista Española de Micropaleontología, 26: 117-143.

Neagu, T., 1995. Early Cretaceous Trocholina group and some related genera from Romania. Part II. Revista Española de Micropaleontología, 27: 5-40.

Olszewska, B., 2005. Microfossils of the Cieszyn Beds (Silesian Unit, Polish Outer Carpathians) - a thin sections study. Polish Geological Institute, Special Papers, 19: 1-58.

Olszewska, B., 2010. Microfossils of the Upper Jurassic - Lower Cretaceous formations of the Lublin Upland (SE Poland) based on thin sections studies. Polish Geological Institute, Special Papers, 26: 1-56.

Permyakov, V.V., Borisenko, L.S., M. V. Vanina, et al. 1984 Yurskaya sistema (in Russian). In: Geologiya shelfa USSR. Stratigrafiya (shelf i poberezhye Chernogo morya): 42-58. Naukova Dumka, Kiev.

Petrova, S., Rabrenović, D., Lakova, I., Koleva-Rekalova, E., Ivanova, D., Metodiev, L., Malešević, N., 2012. Biostratigraphy and microfacies of the pelagic carbonates across the Juras sic/Cretaceous boundary in eastern Serbia (Stara Planina-Poreč Zone). Geologica Balcanica, 41: 53-76.

Platonov, E.S., Arkad'ev, V.V., 2011. Granitsa yury i mela v vostochnom Krymu po ammonitam i tintinnidam (in Russian). In: Tempy evolyutsii organicheskogo mira i biostratigrafiya: 98-100. Materialy LVII Sess. Paleontol. Ob-va pri RAN, St. Petersburg.

Platonov, E.S., Lakova, I., Arkad'ev, V.V., 2013. Tintinnids from the Jurassic-Cretaceous boundary deposits of the Eastern Crimea (in Russian). In: Jurassic System of Russia: Problems of Stratigraphy and Palaeogeography (ed. V.A. Zakharov): 169-171. Abstract book. Fifth all-Russian meeting, Tyumen.

Platonov, E., Lakova, I., Petrova, S., Arkad'ev, V.V., 2014 Tithonian and Lower Berriasian calpionellid against ammonite biostratigraphy of the Dvuyakornaya Formation in eastern Crimea. Geologica Balcanica, 43: 63-76.

Pop, G., 1997. Tithonian to Hauterivian praecalpionellids and calpionellids: bioevents and biozones. Mineralia Slovaca, 29: 304-305.

Pruner, P., Houša, V., Olóriz, B., Košták, M., Krs, M., Man, O. Schnabl, P., Venhodová, D., Tavera, J.M., Mazuch, M., 2010 High-resolution magnetostratigraphy and biostratigraphic zonation of the Jurassic/Cretaceous boundary strata in the Puerto Escaño section (southern Spain). Cretaceous Research 31: 192-206.

Reháková, D., 2000a. Evolution and distribution of the Late Jurassic and Early Cretaceous calcareous dinoflagellates recorded in the Western Carpathians pelagic carbonate facies. Mineralia Slovaca, 32: 79-88.

Reháková, D., 2000b. Calcareous dinoflagellate and calpionellid bioevents versus sea-level fluctuations recorded in the West-Carpathian (Late Jurassic/Early Cretaceous) pelagic environments. Geologica Carpathica, 51: 229-143.

Reháková, D., Michalík, J., 1997. Evolution and distribution of calpionellids - the most characteristic constituents of Lower Cretaceous Tethyan microplankton. Cretaceous Research, 18: 493-504.

Reháková, D., Matyja, B., Wierzbowski, A., Schlögl, J., Krobicki, M., Barski, M., 2011. Stratigraphy and microfacies of the Jurassic and lowermost Cretaceous of the Veliky Kamenets section (Pieniny Klippen Belt, Carpathians, Western Ukraine). Volumina Jurassica, 9: 61-104.

Řehánek, J., 1985. Colomisphaera conferta n. sp. (Stomiosphaeridae Wanner, 1940) from the Lower Cretaceous of the West Carpathians. Věstník Ústředního ústavu geologického, 60 171-174.

Rehánek, J., 1992. Valuable species of cadosinids and stomiosphaerids for determination of the Jurassic-Cretaceous boundary (vertical distribution, biozonation). Scripta, 22: 117-122.

Remane, J., Borza, K., Nagy, I., Bakalova-lvanova, D., Knauer, J., Pop, G., Tardi-Filácz, E., 1986. Agreement on the subdivision of the standard calpionellid zones defined at the IInd Planktonic Conference, Roma 1970. Acta Geologica Hungarica, 29: 5-14.

Retowski, O., 1894. Die Tithonische Ablagerungen von Theodosia. Ein Beitrag zur Paläontologie der Krim. Bulletin de la Société impériale des Naturalistes de Moscou. Nouvelle Série, 7: 206-301.

Riegraf, W., Luterbacher, H., 1989. Oberjura-Foraminiferen aus dem Nord- und Sudatlantik (Deep Sea Drilling Project Leg 1-79). Geologische Rundschau, 78: 999-1045.

Sazonova, I.G., Sazonov, N.T., 1984. Berrias borealnykh provintsiy Evropy (in Russian). Byuletin Moskovskogo obshchestva ispytateley prirody, otdelenie geologii, 59: 86-98.

Schlagintweit, F., Ebli, O.M., 1999. New results on microfacies, biostratigraphy and sedimentology of Late Jurassic-Early Cretaceous platform carbonates of the Northern Calcareous Alps. Part I: Tressenstein Limestone, Plassen Formation. Abhandlungen der Geologischen Bundesanstalt, 56: 379-419.

Schlagintweit, F., Gawlick, H.J., 2007. Analysis of Late Jurassic to Early Cretaceous algal debris-facies of the Plassen carbonate platform in the Northern Calcareous Alps (Germany, Austria) and in the Kurbnesh area of the Mirdita zone (Albania): a tool to reconstruct tectonics and palaeogeography of eroded platform. Facies, 53: 209-227.

Schnabl, P., Pruner, P., Wimbledon, W.A.P., 2015. A review of magnetostratigraphic results from the Tithonian-Berriasian of Nordvik (Siberia) and possible biostratigraphic constraints. Geologica Carpathica, 66: 489-498.

Shchennikova, A.S., Arkad'ev, V.V., 2009. Tintinnidy (Tintinnoidae Infusoria) iz titon-berriasskikh otlozheniy Gornogo Kryma (in Russian). Materialy LV sessii Paleontologicheskogo obshchestva Rossiyskoy Akademii nauk: 166-167

Septfontaine, M., 1977. Niveaux à Foraminifères (Pfenderininae et Valvulininae) dans le Dogger des Préalpes médians du 
Chablais occidental Haute-Savoie, France). Eclogae Geologicae Helvetiae, 70: 599-635.

Smirnova, T.N., 1962. Rasprostraneniye nizhnemelovykh brakhiopod Kryma i Severnogo Kavkaza (in Russian). Byuletin Moskovskogo obshchestva ispytateley prirody, otdelenie geologii, 35: 132.

Sokolov, V.D., 1886. Materialy dlya geologii Kryma. Krymskiy titon (in Russian). Izvestia Moskovshogo Ob-va Lyubitelei Estestvoznaniya, Antropologii i Etnografii, 14: 1-43.

Speranza, F., Satolli, S., Mattioli, E., Calamita, F., 2005. Magnetic stratigraphy of Kimmeridgian-Aptian sections from Umbria-Marche (Italy): new details on the M polarity sequence. Journal of Geophysical Research, 110: B12109.

Svobodová, A., Košták, M., 2016. Calcareous nannofossils of the Jurassic-Cretaceous boundary strata in the Puerto Escaño section (southern Spain) - biostratigraphy and palaeoecology. Geologica Carpathica, 67: 223-238.

Tarling, D.H., Hrouda, E., 1993. The Magnetic Anisotropy of Rocks. Chapman and Hall, London.

Tesakova, E.M., Savel'eva, Y.N., 2005. Ostracods from Jurassic/Cretaceous boundary layers of the eastern Crimea: stratigraphy and paleoecology. In: Paleobiologiya i detal'naya stratigrafiya fanerozoya: 135-155. Izd. MGU, Moscow.
Velić, I., 2007. Stratigraphy and palaeobiogeography of Mesozoic benthic foraminifera of the Karst Dinarides (SE Europe). Geologia Croatica, 60: 1-113.

Weynschenk, R., 1956. Some rare Jurassic index foraminifera. Micropaleontology, 2: 283-286.

Wimbledon, W.A.P., Reháková, D., Pszczółkowski, A., Casellato, C.E., Halásová, E., Frau, C., Bulot, L.G., Grabowski, J., Sobień, K., Pruner, P., Schnabl, P., Čížková, K., 2013. An account of the bio- and magnetostratigraphy of the Upper Tithonian-Lower Berriasian interval at Le Chouet, Drôme (SE France). Geologica Carpathica, 64: 437-460.

Yanin, B.T., Baraboshkin, E.J., 2010. Melovaya sistema Rossii i blizhnego zarubezhia: problemy stratigrafii i paleogeografii (in Russian). In: Materialy Pyatogo Vserossiyskogo soveshchaniya (eds. E.J. Baraboshkin and I.V. Blagoveshensky): 364-366. ULGU, Ulyanovsk.

Yanin, B.T., Smirnova, T.N., 1981. Stratigraficheskoye rasprostraneniye dvustvorchatykh mollyuskov i brakhiopod $v$ berriase i valanzhine Kryma (in Russian). Byuletin Moskovskogo obshchestva ispytateley prirody, otdelenie geologii, 56: 82-94. 